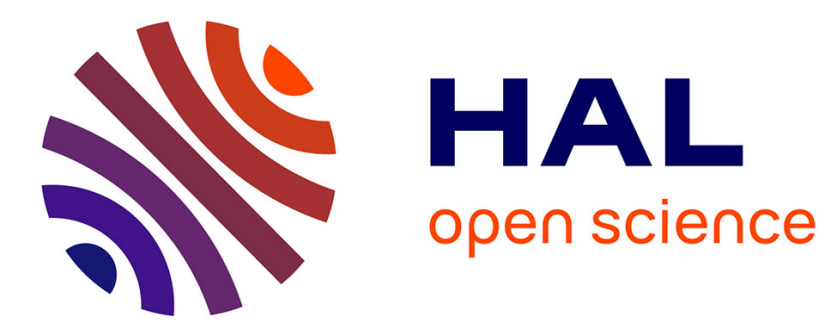

\title{
Spider conservation in Europe: a review
}

F. Milano, T. Blick, P. Cardoso, M. Chatzaki, C.S. Fukushima, P. Gajdoš, A.T. Gibbons, S. Henriques, N. Macías-Hernández, S. Mammola, et al.

\section{To cite this version:}

F. Milano, T. Blick, P. Cardoso, M. Chatzaki, C.S. Fukushima, et al.. Spider conservation in Europe: a review. Biological Conservation, 2021, 256, pp.109020. 10.1016/j.biocon.2021.109020 . hal-03225316

\section{HAL Id: hal-03225316 https://hal.science/hal-03225316}

Submitted on 14 Oct 2021

HAL is a multi-disciplinary open access archive for the deposit and dissemination of scientific research documents, whether they are published or not. The documents may come from teaching and research institutions in France or abroad, or from public or private research centers.
L'archive ouverte pluridisciplinaire HAL, est destinée au dépôt et à la diffusion de documents scientifiques de niveau recherche, publiés ou non, émanant des établissements d'enseignement et de recherche français ou étrangers, des laboratoires publics ou privés. 


\section{Spider conservation in Europe: a review}

Filippo Milano a,1, Theo Blick ${ }^{b}$, Pedro Cardoso ${ }^{c}$, Maria Chatzakid, Caroline Sayuri Fukushimac, Peter Gajdoše, Alastair T. Gibbons ${ }^{f}$, Sergio Henriques ${ }^{g, h, i}$, Nuria Macías-Hernández ${ }^{c, j}$, Stefano Mammola ${ }^{c, k}$, Wolfgang Nentwig', Myles Nolan ${ }^{m}$, Julien Pétillonn ${ }^{n}$ Nina Polchaninova ${ }^{\circ}$, Milan Řezáčp ${ }^{2}$ Jonas Sandströmq ${ }^{q}$, Helen Smithr, Konrad Wiśniewskis ${ }^{\mathrm{s}}$ Marco Isaia ${ }^{\mathrm{a}, 1, *}$

aDepartment of Life Sciences and Systems Biology, University of Turin, Italy

bHummeltal, Germany

cLaboratory for Integrative Biodiversity Research (LIBRe), Finnish Museum of Natural History (LUOMUS), University of Helsinki, Finland

dDepartment of Molecular Biology and Genetics, Democritus University of Thrace, Greece eInstitute of Landscape Ecology, Slovak Academy of Sciences, Bratislava, Branch Nitra, Slovakia

fSchool of Life Sciences, University of Nottingham, University Park, Nottingham NG7 2RD, UK Institute of Zoology, Zoological Society of London, Regent's Park, London NW1 4RY, UK

hDepartment of Genetics, Evolution and Environment, Centre for Biodiversity \& Environment Research, University College London, Gower Street, London WC1E 6BT, UK

'Global Center for Species Survival, Indianapolis Zoological Society, 1200 West Washington Street, P.O. Box 22309, Indianapolis, Indiana 46222, USA

jDepartment of Animal Biology, Edaphology and Geology, University of Laguna, La Laguna, Tenerife, Canary Islands, Spain

kMolecular Ecology Group (MEG), IRSA - Water Research Institute, National Research Council, Verbania Pallanza, Italy

IInstitute of Ecology and Evolution, University of Bern, CH-3012 Bern, Switzerland

${ }^{\mathrm{m}} \mathrm{c} / \mathrm{o}$ National Museum of Ireland - Natural History, Merrion St, Dublin 2 D02 F627, Ireland

nUMR CNRS 6553 Ecobio, Université de Rennes, France

○V.N. Karazin Kharkiv National University, Maidan Svobody 4, 61027 Kharkiv, Ukraine

PFunction of Invertebrate and Plant Biodiversity in Agrosystems - Crop research Institute, Drnovska 507, CZ16106 Praha 6 - Ruzyne, Czechia

aSwedish University of Agricultural Sciences, Swedish Species Information Centre, Box 7007, S-75007 Uppsala, Sweden

'British Arachnological Society, Waveney Cottage, Redgrave Road, South Lopham, Diss IP22 2JN, UK sInstitute of Biology and Earth Sciences, Pomeranian University in Słupsk, Arciszewskiego 22b, 76-200 Słupsk, Poland

${ }^{*}$ Corresponding author.

E-mail address: marco.isaia@unito.it (M. Isaia).

${ }^{1}$ Equal contributions. 


\section{Abstract}

Despite their ecological importance and diversity, spiders (Arachnida: Araneae) are underrepresented in conservation policies in comparison to other groups. We review all extant conservation tools focusing on spiders in Europe, highlighting general patterns, limitations, gaps, and future directions. We assembled a comprehensive online database reporting all available information concerning the legal protection and conservation status of 4,154 spider species. Existing international legislation has limited coverage, with only one species listed in the Bern Convention and EU Habitats Directive. At the national and subnational levels, 178 species are formally mentioned in the legislation of 19 European countries. Moreover, the International Union for Conservation of Nature (IUCN) includes assessments for 301 species worldwide, 164 of these threatened and eight native to Europe. In addition, spiders are mentioned in Regional Red Lists and Red Books in 28 out of 42 European countries considered in this review. Northern and Central European countries have the highest percentage of species assessed at the regional level in Red Lists and Red Books. The Mediterranean basin has the highest spider diversities in Europe but conservation efforts are lacking, both in terms of assessments and national or subnational legislation. Among European species, Dolomedes plantarius, Argyroneta aquatica and Eresus kollari are the most frequently mentioned in European conservation measures, possibly due to their ecological traits and their strict association with declining habitats. Considering the current threats to spiders in Europe, the protection of large areas of suitable habitat should be considered as the most effective approach to spider conservation.

Keywords: IUCN, invertebrate conservation, Araneae, Red List, environmental legislation, threatened species

\section{Accepted manuscript}


Table of contents

1. Introduction

2. Data sources

Disclaimer on taxonomy and terminology used in this work

3. International conservation tools

Bern Convention

Habitats Directive

IUCN Red Lists and Red Data Books

Spider species occurring in Europe mentioned in international conservation tools

4. Regional conservation tools

Spider conservation in European countries

Red Lists and Red Data Books of spiders in Europe

Threatened spider species in Red Lists and Red Data Books across Europe

Spiders in legislation in European countries

5. Spider species of conservation concern in Europe

6. Perspectives and conclusions

Ongoing conservation actions in Europe

Concluding remarks

Acknowledgements

References 


\section{INTRODUCTION}

Compared to other animal groups, especially vertebrates, invertebrates have similar or even higher extinction rates and proportions of threatened species (Cardoso et al., 2011), and are in urgent need of protection and monitoring (Cardoso et al., 2020; Samways et al., 2020). Yet, in conservation programmes invertebrates are largely neglected, both at regional and international scales. In addition, despite the global dominance of invertebrates in terms of richness, abundance, biomass and importance in ecosystem functioning (Stork, 2018; Wilson, 1987), the majority of biodiversity conservation research and effort is currently focussed on a few, well-known vertebrate taxa (Clark and May, 2002; Cardoso et al., 2011; Davies et al., 2018; Fukushima et al., 2020; Leather, 2013; Mammola et al., 2020b; Titley et al., 2017).

Among terrestrial invertebrates, spiders (Arachnida: Araneae) are one of the most important groups in terms of abundance, diversity, biomass, evolutionary history, and functional roles (Cardoso et al., 2008; Coddington and Levi, 1991; Coddington et al., 1991, 2009; Dunlop et al., 2018; Foelix, 2011; Jocqué et al., 2013; Mammola et al., 2017b; Nentwig, 2013; Turnbull, 1973). With more than 48,000 species currently described (World Spider Catalog, 2020), spiders are among the most common and ubiquitous animals in the majority of terrestrial habitats, where they play an important role as generalistic predators (Turnbull, 1973). A few species have even conquered the aquatic environment (McQueen and McLay, 1983; Seymour and Hetz, 2011). Spider assemblages are particularly diverse in richly vegetated areas, but they can also be found in habitats with stringent environmental constraints such as deserts, caves, and alpine habitats.

Preserving spider diversity, apart from being ethical in the framework of establishing a sustainable relationship with wildlife in general, is essential in recognition of the fact that they play a fundamental ecological role. They are an important food source for higher trophic levels (e.g. reptiles, birds, mammals) and are predators in most terrestrial ecosystems (Nyffeler and Birkhofer, 2017), thus providing vital ecosystem services to humans with respect to the control of arthropod pests in agroecosystems (King and Hardy, 2013; Michalko et al., 2019). Moreover, their silk, venom and hemolymph are a source of inspiration for biological engineering (Heim et al., 2009; Ko and Wan, 2018), pharmacology, and medicine (Corzo and Escoubas, 2003; Pineda et al., 2018; Riciluca et al., 2012). Yet, compared to more popular groups of invertebrates, spiders are lagging in conservation

\section{Accepted manuscript}


studies and policies worldwide. For example, only one species among the nearly 4,500 spider species known from Europe, is listed in the EU Habitats Directive, whereas 50 butterflies out of 496 and 16 dragonflies out of 143 feature, demonstrating a remarkable taxonomic bias even within invertebrates (Cardoso, 2011). Furthermore, extinction risk has been assessed for fewer than 100 European species in the Global Red List of the International Union for Conservation of Nature (IUCN), mostly from the Macaronesian archipelagos of Madeira and Selvagens (Cardoso et al., 2017). By comparison, the extinction risk of $97 \%$ of European butterflies (van Swaay et al., 2010) and dragonflies (Kalkman et al., 2010) has been assessed.

We reviewed all international and regional conservation tools focusing on spider conservation in Europe, with the goal of highlighting general patterns, limitations, gaps, and future directions in the field of spider conservation. As a result, we compiled a thorough database reporting all available information about the conservation of spiders in European countries, noting Red Lists, Red Books, and any supranational, national and subnational legal acts referring to spiders (see Table A1 in Appendix A and Milano et al., 2021a, b). We also intend to add this information to the joint European network "Araneae - Spiders of Europe" (Nentwig et al., 2020).

\section{DATA SOURCES}

Conservation tools concerning spiders in Europe were investigated at international and regional levels. These included international conventions, regulations and EU Directives, national and subnational acts in force in the European countries considered, the IUCN Red List of Threatened Species, Regional Red Lists and Red Data Books. An overview of the conservation tools currently dealing with spiders in Europe is presented in Table 1.

We examined 42 European countries that are included in the European spider network "Araneae - Spiders of Europe" (Nentwig et al., 2020). Enclave and semi-enclave countries (Monaco, San Marino, and Vatican City), non-independent countries (Andorra), North African and South Caucasian countries, as well as the Outermost Regions and Overseas Countries and Territories of European countries were excluded. Russia is not considered in

\section{Accepted manuscript}


this review, due to the lack of a national Red List for spiders and the difficulty of comparing the numerous (at least 140) regional non-IUCN Red Data Books (Popov et al., 2017).

In order to have a standard reference for all countries considered, we derived national species checklists from the most recent version of "Araneae - Spiders of Europe" (Nentwig et al., 2020). Updates or changes to national checklists not implemented in this source were not considered.

For each country examined, we obtained all the published local Red Lists, Red Books and legal acts concerning spiders, by means of literature surveys and with the assistance of a wide network of local experts and contributors (see acknowledgements). Whenever a country was not covered, information was derived from bibliographic surveys. We considered only the most recent versions of the regional Red Lists and Red Data Books and the currently valid legislation, and we carried out separate analyses on the different geographic levels adopted in each.

To ensure comparability, we assumed the categories of threat from different category systems as equivalent. Species listed as "Critically Endangered (Possibly Extinct)" were considered as Critically Endangered (CR). Species not evaluated or listed in the category "Not Applicable" (NA), were not considered in this review, as they are ineligible for assessment (IUCN, 2012b).

\section{Disclaimer on taxonomy and terminology used in this work}

The nomenclature used in this work refers to the latest version of the World Spider Catalog (2020). Species assessed by Red Lists or Red Books currently regarded as nomina dubia were not considered. For species split subsequently into multiple species, we applied the original assessments to the new species and note the taxonomic changes. In the case of a species lumped with another assessed within a different IUCN category, we adopted a precautionary approach and retained the higher risk category. Synonymies, misidentifications, and nomenclatural changes all followed current taxonomy as represented in the World Spider Catalog (2020). As a consequence, the final number of species reported in this review may differ from the number assessed in the original Red Lists and Red Data Books.

According to the definition of the IUCN (IUCN, 2012a), we used the term "Regional" in reference to any sub-global geographical level of assessment. However, here we used the terms "national", "subnational" and "supranational" Red Lists in order to discriminate the

\section{Accepted manuscript}


level at which the regional assessment was performed. The term "Global" is used when referring to the IUCN Red List of Threatened Species. We use the term "international" to define tools involving more than one country, irrespective of whether they have a European (Bern Convention and Habitats Directive) or global origin (IUCN).

\section{INTERNATIONAL CONSERVATION TOOLS}

Among the extant international tools focusing on the preservation of nature in Europe, very few mention European spiders. They are limited to the Bern Convention, the Habitats Directive and the Red List of Threatened Species of the IUCN. The Convention on International Trade in Endangered Species of wild fauna and flora (CITES) also considers spiders, but none of the spider species mentioned therein occur naturally in Europe, and therefore it is not considered in this work (for details, see Table 1 and Appendix B).

\section{Bern Convention}

The Bern Convention (Council of Europe, 1979), is the first formal international convention providing specific attention to the conservation of species in Europe, including spiders. A provisional list of candidate invertebrate species was initially proposed for inclusion in the Convention by the IUCN Conservation Monitoring Centre (Collins and Wells, 1987). The list was subsequently adopted by the Standing Committee as the basis for additions to the appendices of the Convention.

Two spider species were included in the provisional list: Dolomedes plantarius (Clerck 1757) (Pisauridae) and Macrothele calpeiana (Walckenaer 1805) (Macrothelidae), but only the latter was retained in the Bern Convention. Macrothele calpeiana is currently listed in the "strictly protected fauna" of Appendix II, granting it special protection against all forms of disturbance, capture, keeping, deliberate killing, and damage or destruction of breeding or resting sites. The restricted distribution of $M$. calpeiana (back then regarded as endemic to the Southern Iberian Peninsula), and the fragmentation and destruction of its putative preferred habitat in cork oak forests (Quercus suber L.), represented the main reasons for its inclusion in the Convention (Snazell, 1986; Snazell and Allison, 1989).

\section{Accepted manuscript}




\section{Habitats Directive}

Following on from the Bern Convention, the Habitats Directive (92/43/EEC) was the first international law to regulate European conservation policy concerning spiders.

Once again, the only spider species mentioned in the Habitats Directive is M. calpeiana, listed in Annex IV among the species of European interest in need of strict protection. Unlike the Bern Convention, the Directive is mandatory, and the Member States are obliged to protect and monitor the conservation status of $M$. calpeiana and its habitat (Article 12), particularly through the establishment of a network of protected sites. Its main range of distribution is included in, or close to, Natura 2000 network sites and protected areas in the South-Western Iberian Peninsula. The inclusion of this species in the Habitats Directive was a consequence of its appearance in the Bern Convention, which deeply influenced the Directive in both conception and drafting, and constituted the basis for the composition of the lists in the Directive's Annexes (Epstein, 2013; van Helsdingen and Decae, 1992).

\section{IUCN Red Lists and Red Data Books}

The IUCN was established in 1948, and was the first international network to consider spiders in conservation issues. One of the most important tools promoted by the IUCN is the Red List of Threatened Species (or, the "Global" Red List), established in 1964 and widely accepted as the most comprehensive and objective source of information on the conservation status of species and their extinction threats (Lamoreux et al., 2003; Rodrigues et al., 2006; but see Cardoso et al., 2011, 2012). The Global Red List is based on a number of objective criteria, which are relatively easy to apply, repeatable and scientifically recognized as adequate indicators of the health of global biodiversity (IUCN, 2001).

The first IUCN Red List of Threatened Animals was published in 1986 by the IUCN Conservation Monitoring Service and it included 18 spider species, amongst which were the spiders mentioned in the first IUCN Invertebrate Red Data Book published three years before (Wells et al., 1983). This provided information on the threats to survival and conservation needs of six spider species: the theraphosid Brachypelma smithi, three

\section{Accepted manuscript}


subterranean linyphiids (Troglohyphantes gracilis Fage 1919, T. similis Fage 1919, and T. spinipes Fage 1919), and two lycosids (Adelocosa anops Gertsch 1973 and Pardosa diuturna Fox 1937).

Currently, 301 spider species are listed in the Global IUCN Red List (IUCN, 2021). Three are Extinct, 164 are assigned to one of the three categories of risk (Critically Endangered, Endangered, Vulnerable), and 97 are in Near Threatened or Least Concern categories; further 37 species are in the Data Deficient category). Almost half of the species listed in the IUCN Red List are endemic to the Seychelles Islands (IUCN, 2021). This disproportion is due to the work of Gerlach (2014), who provided the first comprehensive assessment based on formal IUCN criteria of spiders within a geographically restricted region.

More recently, Red Lists and Red Books have been drawn up for geographic areas at different spatial scales (i.e. at the regional level) and for different purposes. Regarding the spatial scales, species evaluated as threatened in the Global Red List are considered endangered worldwide, but this assessment may not coincide with their conservation status at a national or subnational level. While the Global Red List addresses the current and future conservation status of species, i.e. their relative risk of extinction, Regional Red Lists may contribute to the effective conservation of threatened species on a smaller scale, influencing their protection and recovery. Regarding the purposes, whilst Red Books generally contain in-depth analyses of species' status, distribution, factors of decline and conservation measures, Red Lists are usually shorter and more specific, presenting concise references to distribution and status. Table 2 details those European countries which have used IUCN and Red List approaches to spider conservation.

\section{Spider species occurring in Europe mentioned in international conservation tools}

International conservation tools offer significant opportunities for the conservation and protection of biodiversity due to their cross-border approaches, long-term commitments, and consideration of the biology of the species (Trouwborst et al., 2017). Species distributions are seldom confined within national boundaries and conservation is an international concern that requires active collaboration among countries through trans-national actions.

At present, only nine spider species out of $>4,000$ occur in Europe (Nentwig et al., 2020) are considered in international conservation tools. One is included in the Bern Convention and 9

\section{Accepted manuscript}


in the Habitats Directive, whilst the remaining eight are listed in the Global IUCN Red List of threatened species (IUCN, 2021).

The only spider mentioned in the Bern Convention and the Habitats Directive is Macrothele calpeiana. However, doubts have been raised regarding the needs of protection of this species and the ecological consequences of its ongoing spread in Europe probably due to commercial export of olive trees (Jiménez-Valverde et al., 2011; further details in the section "Spider species of conservation concern in Europe").

Importantly, the conservation status of $M$. calpeiana has been recently assessed according to the IUCN criteria (Branco et al., 2019), proving this species to be eligible for the Least Concern category.

Eight native European spiders are listed in the global IUCN Red List of threatened species (IUCN, 2021):

- Anapistula ataecina Cardoso \& Scharff 2009 (Symphytognathidae): a cave-dwelling spider endemic to a geographically restricted karst system in southern Portugal (Cardoso and Scharff, 2009), regarded as Critically Endangered (Cardoso, 2010).

- Dolomedes plantarius (Pisauridae): a semi-aquatic spider species with a Eurosiberian distribution. As a result of habitat loss and degradation, in 1996 the species was classified as Vulnerable by IUCN (World Conservation Monitoring Centre, 1996a). Because it was assessed before the publication of the new IUCN standards (version 3.1, 2001), the evaluation of $D$. plantarius is outdated and hard to compare with more recent ones.

- Macrothele cretica Kulczyński 1903 (Macrothelidae): a species endemic to Crete. Until recently, information was inadequate for evaluation of the global risk of extinction, and it was therefore listed as Data Deficient (World Conservation Monitoring Centre, 1996b). This species is listed as Vulnerable in the Red Book for Greece (Chatzaki, 2009).

- Nothophantes horridus Merrett \& Stevens 1995 (Linyphiidae): Critically Endangered in the global IUCN Red List (Cardoso and Hilton-Taylor, 2015). Thought to be a subterranean-specialist living in limestone fissures, this species is endemic to the UK, where it is known from only three locations in the Plymouth area. It is considered Endangered on the British Red List (Harvey et al., 2017), and is listed in Section 41 
of the Natural Environment and Rural Communities Act (2006) as a Species of Principal Importance in England.

- Vesubia jugorum (Simon 1881) (Lycosidae): a spider endemic to high altitude rocky areas in the South-Western Alps, straddling the border between France and Italy (Mammola et al., 2016). This species was listed as Endangered in the Global IUCN Red List of Threatened species on the basis of its limited geographic range and the predicted reduction of its natural habitat in the near future due to climate change (Isaia and Mammola, 2018).

- Troglohyphantes gracilis, T. similis and T. spinipes (Linyphiidae): three subterranean species restricted to Slovenia (Mammola et al., 2018a), where they figure in the national Red List due to their rarity (category R) (Uradni list Republike Slovenije, 2002). These species were listed in the first IUCN Red List (IUCN Conservation Monitoring Service, 1986) due to their restricted geographical distribution, and were assessed as Vulnerable in the 1996 IUCN Red List (World Conservation Monitoring Centre, 1996c, d, e), but their status has not been updated since.

\section{REGIONAL CONSERVATION TOOLS}

Of the European countries which have enacted legislation to safeguard and manage species within their territory, 19 have legislated in some way for spiders. Spider conservation is also promoted by regional Red Lists in 28 countries: we refer to those based on IUCN Criteria as "IUCN Red Lists" and those which do not strictly follow IUCN standards as "non-IUCN Red Lists".

\section{Spider conservation in European countries}

Essential up-to-date information on current spider conservation from each country are presented in Tables 2 and 3. Due to space limitations, a detailed overview referring to (1) Regional IUCN Red Lists implemented at the national or subnational level, (2) Regional nonIUCN Red Lists, and (3) any legislation mentioning spiders promoted by the countries involved, is reported in Appendix B.

\section{Accepted manuscript}




\section{Red Lists and Red Data Books of spiders in Europe}

A first review on spiders in European Red Lists reporting data from seven countries was published in 2000 (Franc, 2000). Since then, 20 countries have adopted national or subnational red lists considering spiders as an appropriate basis for prioritising and developing national conservation policies. Among the 42 European countries considered in this review, 28 (67\%) currently have a list of threatened spider species, 20 of which operate at national level. Eight countries have Red Lists only at the subnational level, whilst seven countries have both national and subnational lists. Figure 1 provides the geographic distribution of national Red Lists and Red Books in the European countries.

Different criteria were used for assessing the conservation status of species. Several threatened species datasets in Europe follow IUCN criteria, but some countries utilise alternative categories and criteria. The IUCN assessment process has received wide acceptance and is being used consistently at national and other regional scales (Gärdenfors, 2001). Ten countries based their national Red Lists or Red Data Books on the most recent version of IUCN criteria (IUCN, 2001, 2012b), namely Bulgaria, Croatia, Denmark, Finland, Greece, Kosovo, Norway, Spain, Sweden and Great Britain. Slovakia adopted the 1994 IUCN criteria for their national lists (IUCN, 1994), whilst Latvia and Lithuania adopted a pre1994 version.

The remaining countries with national inventories used national guidelines (see Blick et al., 2016), or based them on expert opinion (see, e.g., Groppali and Priano, 1992), or utilised modified IUCN Categories and Criteria (see for example Głowaciński and Nowak, 2004, Řezáč et al., 2015 and Staręga et al., 2002). Many such Red Lists were developed before the regional IUCN guidelines were published, as is the case with Germany where a standardised assessment scheme was developed and has been maintained since the 1970s by the Federal Agency of Nature Conservation (DS/IRV, 1971; Sukopp, 1974). As previously noted, other national lists were drawn up using alternative and highly individual categorization systems, for example, Italy (Groppali and Priano, 1992) and Slovenia (Uradni list Republike Slovenije, 2002). In these inventories categories of risk differ widely and criteria and category definitions are often neither explicit nor transparent.

In addition to national Red Lists, the Czech Republic, Denmark, Germany, Italy, Poland, Slovakia, and Spain also have subnational ones, which assess the conservation status of 
spiders in one or more specific regions or districts of the country. Germany has the highest number of inventories of threatened spiders (13), including the national list and the supranational list (Wadden Sea).

Eight countries have supra- or subnational Red Lists but no national one. In France, spiders occurring in Nord-Pas-de-Calais and Picardie were assessed following the regional IUCN guidelines (Groupe ornithologique et naturaliste du Nord-Pas-de-Calais, 2018; Picardie Nature, 2016). As a result of the IUCN assessment carried out for selected taxonomic groups occurring in the whole Carpathian Region (Kadlečík, 2014; Mateleshko and Potish, 2011) a certain proportion of spiders in the Carpathian areas of Hungary, Romania, Serbia and Ukraine have been assessed according to IUCN guidelines. Furthermore, in Ukraine, there are also two other regional Red Lists (Tokarsky, 2013; Zalevskiy and Bronskov, 2017), drafted according to the national criteria adopted by the Red Book of Ukraine (Akimov, 2009).

The remaining countries (Austria, Belgium, Netherlands) used national criteria (e.g., Komposch and Steinberger, 1999) or regional IUCN guidelines which were integrated with different systems of evaluation (e.g., Maelfait et al., 1998 and Vangsgård et al., 1996). In Belgium (Maelfait et al., 1998), where the conservation of nature is responsibility of the regional governments, the Flemish red list of spiders is based on the 1994 IUCN criteria (IUCN, 1994) and on the criteria used in Germany (Schnittler et al., 1994). In the Red Book of the Wadden Sea area (von Nordheim et al., 1996), the approach to assessment is based on a combination of the IUCN criteria and the German (Blab et al., 1984) and the Danish (Asbirk and Søgaard, 1991) systems. The geographic distribution of the subnational Red Lists in the European countries is displayed in Figure C3 Appendix C.

Although many European countries and regions now have Red Books and Lists of their threatened spiders, the lack of standardisation in the categories and criteria used is problematic. The alteration or misinterpretation of IUCN guidelines may lead to confusion if modifications of the criteria are not explicitly stated (Miller et al., 2007). If it were the case that every country applied its own approach, the criteria adopted would be subject to high levels of subjectivity which would reduce the comparability among regional Red Lists. For example, terms such as "vulnerable" or "endangered" have different meanings according to different evaluation systems. In addition, the category "rare" is used by several authors (Blick et al., 2016; Groppali and Priano, 1992; Komposch and Steinberger, 1999; Maelfait et al., 
1998) even though it pertains to the ecological characteristics of a species rather than its category of risk (de Grammont and Cuarón, 2006).

Such variation in national listings makes it difficult to synthesize information from different countries which is vital in order to create a general overview; this, in turn, can hamper efforts to consolidate information and provide recommendations.

To reduce bias and limit these inconsistencies, we recommend that standardised categories and criteria, as well as a unified categorisation system, are implemented and utilised. Currently, the only widely adopted system worldwide is the one by IUCN, which theoretically allows comparison of results from different countries and taxa under a common framework. This could be adopted across countries to guarantee such comparability and hence contributing to analyses beyond national borders. An effort must be made to guarantee similar interpretation of criteria, which is often hard and rarely accomplished, but essential for future protection of species whose ranges span different countries.

\section{Threatened species in Red Lists and Red Data Books across Europe}

One of the main problems facing spider conservation in Europe is the general lack of information on their true conservation status. Data are incomplete in the vast majority of the spider species, and are usually limited to the knowledge of their national occurrence. Detailed information on national distributions of species, ecological requirements, and threats affecting them at the regional level, are available only for certain countries. Efforts have been made primarily in Central and North-Western European countries, where national inventories of threatened species cover the highest percentage of resident spider species.

Overall, 1,552 (37\%) of the 4,154 spider species currently known in the European countries considered (Nentwig et al., 2020) are assessed by regional inventories focusing on their conservation status. Czech Republic, Denmark, Finland, Germany, Norway, Sweden and the UK, list the majority of their native spider fauna, all with coverage $>90 \%$ (Figure 3 ). This can be attributed to these countries having a greater number of arachnologists and local experts, resulting in a broader understanding of the spider fauna occurring within their national borders and, consequently, in higher numbers of spiders being assessed in national

\section{Accepted manuscript}


inventories (see Table C3 in Appendix C). Conversely, in many other countries, only iconic species have been comprehensively assessed. The countries with the lowest species assessed-known ratio are Belarus and Lithuania (both $0.2 \% ; 1$ species out of 481 and 476 , respectively), followed by Bulgaria $(0.5 \% ; 5$ species out of 1,045) and Latvia $(0.8 \% ; 4$ species out of 502). This low coverage in the assessment of native spider species is likely due to the scant number of local arachnologists and to the related deficit of adequate information with regard to the national distribution of species and their population size and dynamics.

The Mediterranean countries also have a low proportion of spiders assessed. Italy is one of the most species-rich countries in Europe (1,702 spider species), but has only assessed 148 species (8.7\%). In Spain the ratio is even lower, with 10 out of 1386 species (0.7\%) listed in the national Red Book, whilst Greece has 1285 species recorded but only 32 (2.5\%) have been assessed (see Figure 3 for an overall comparison).

This significant lack of information on the status of spider species in the Mediterranean region is mainly the result of taxonomic (many less-known or recently described species) and geographical (only generic or partial data on species distribution range) uncertainty. Even if in some countries most of the species are recognized to be present, little is known regarding their distribution, and the overall knowledge of spiders is far from complete (Cardoso, 2008). Furthermore, the high frequency of endemic species in the Mediterranean countries, which are generally not well known or studied, contributes to the general difficulty in assessing species conservation status.

Regarding supranational Red Lists, the most species-rich list is the Carpathians Red List (Kadlečík, 2014), which considers 1,067 spider species (1,040 according to the current taxonomy) that occur across Czech Republic, Hungary, Poland, Ukraine, Romania, Serbia and Slovakia. This list complements the former version of the IUCN Carpathian List (Witkowski et al., 2003), which listed only 15 species of spiders for the Czech Republic and Slovakia. Other supranational lists available in Europe are the Red List of Upper Silesia, assessing 508 spiders (506 following the current taxonomy) from the Polish and Czech Silesia, and the Red List of the Wadden Sea, with 55 species assessed, occurring across the coastal region along Denmark, Germany and the Netherlands.

All the current Red Lists and Red Books on spiders in Europe were published after 1989, which is the year of publication of the oldest still valid national list on threatened spiders (the 15

\section{Accepted manuscript}


Red Data Book for the Maltese Islands by Schembri and Sultana, 1989). Conversely, Denmark, Finland, Norway, Sweden and the UK have the most recent Red Lists, all published after 2015. Among Central European countries, Germany and Czech Republic have very recent assessments as well (2016 and 2015, respectively).

Due to both the difficulty in comparing the different evaluation systems used to produce national red lists, and to the lack of information on the conservation status of species, any depiction of Europe's threatened spider fauna cannot be complete or balanced. However, the inclusion of certain species in red lists across Europe does provide useful insights into species of conservation concern in Europe in general.

Overall, the highest number of regionally extinct and threatened spider species has been assessed from Central-eastern Europe (Figure 4). Czech Republic has the highest number of species assessed as regionally extinct, 26 out of 893 species occurring nationwide (3\%), followed by Slovakia with 15 species (1.6\%), and Germany with 7 species (0.7\%) considered extinct or lost. Czech Republic also has the highest number of species considered as threatened (360 species, corresponding to more than $40 \%$ of the national spider fauna), followed by Slovakia with 260 species (27\%), Germany with 254 (25\%) and Poland with 206 spider species (24\%).

These results would suggest a geographical pattern with a greater concentration of threatened species in Central and Eastern European countries. However, this picture remains crude. First, different assessment methods have been adopted in drafting national Red Lists so the definition of "threatened" may be inconsistently applied. Second, in some countries, assessments are limited to species supposed to be threatened a priori, i.e. those selected on the basis of expert judgment, without taking into consideration the entire national fauna. Third, some countries consider a limited number of species which are often regionally or ecologically clustered. Fourth, some countries do not even have a national Red List on spiders. Accordingly, these results are preliminary and are limited to those countries which both have a Red List and assess their spiders at national level.

Nevertheless, our results show similar geographic patterns to those seen in other terrestrial invertebrate groups, for which there is more comprehensive information available (Nieto and Alexander, 2010; Nieto et al., 2014; van Swaay et al., 2010). It has been shown that Central and Eastern European countries are hotspots for threatened species within Europe, and it is likely that our results on spiders follow a similar trend. 
It is likely that this trend can be attributed to several factors: high anthropogenic pressure in these countries; agricultural improvements; changes to grassland and woodland management; infrastructure development; the degradation and drainage of wetlands, as well as isolation and loss of habitat connectivity. These threats are mostly in line with those identified as the more relevant to spider species worldwide (Branco and Cardoso, 2020). In addition, it could be argued that intensive environmental changes are more recent in Eastern countries, making the related effects on species more visible than elsewhere in Europe. These factors have led to a considerable decline in terrestrial invertebrates, particularly in Central and Eastern Europe (Birkhofer et al., 2017; Cálix et al., 2018; Farkač et al., 2005; Hallman et al., 2017; Maes et al., 2019; Nieto and Alexander, 2010; Nieto et al., 2014; Seibold et al., 2019; van Swaay et al., 2010, 2012).

These geographical patterns have also been confirmed at a smaller scale. In the Carpathians Red List, the highest number of threatened species was recorded in the Slovak, Czech and Polish Carpathians (Kadlečík et al., 2014). In the Slovak part of the Carpathian Mountains, $1 \%$ of the spider species considered are regionally extinct $(n=13)$ and more than $20 \%$ are threatened. Three spider species are known to occur in this region that are considered extinct in the Czech Carpathians, 25\% of spiders have been assessed as threatened, whilst 15\% are threatened in the Polish Carpathians (Kadlečík et al., 2014). For these regions the main threats are associated with industrialization and agricultural intensification around the mid-20 $0^{\text {th }}$ century, leading to a gradual anthropisation of the territory, and subsequent habitat loss and degradation (Kadlečík et al., 2014).

In Mediterranean Europe, the large-scale transformation in land use over the last few decades, the prevalence of wildfires, tourist developments, and unbridled urbanisation has resulted in large-scale alterations of the natural environment (Cuttelod et al., 2008). This has very likely impacted a high number of spider species and many with restricted ranges are possibly threatened or extinct. However, without accurate knowledge concerning their actual status, the real proportion of threatened species is hard to quantify.

In contrast, Northern European countries have the lowest percentage of threatened species. In Finland, only 21 spiders (3\% of the national spider fauna), are considered threatened, and one species is described as regionally extinct (Hyvärinen et al., 2019). In Sweden, 20 species (3\%) are assessed as threatened, and one as regionally extinct (SLU Artdatabanken, 2020). Norway considers 34 spiders endangered or $5 \%$ of the national

\section{Accepted manuscript}


spider fauna (Henriksen and Hilmo, 2015), whilst Denmark has assessed 79 species as threatened (14\%) and two species extinct (Bruun and Lissner, 2019). In these countries the majority of threatened species live primarily in forests, and thus changes to the forest environment, e.g. forestry, reduction of old forests, reforestation, and forest management, represent the major threats (SLU Artdatabanken, 2020; Bruun and Lissner, 2019; Henriksen and Hilmo, 2015; Hyvärinen et al., 2019). Furthermore, a large proportion of threatened species occur in semi-natural habitats, mainly traditional meadows and pastures, which have declined greatly over the past hundred years (SLU Artdatabanken, 2020; Bruun and Lissner, 2019; Henriksen and Hilmo, 2015; Hyvärinen et al., 2019). Climate change inevitably poses a large threat to species found in northern alpine areas, as well as to species occurring in wetlands and mires (SLU Artdatabanken, 2020; Hyvärinen et al., 2019).

\section{Spiders in legislation in European countries}

Generally, the institutions which most directly influence conservation actions and legislation are national or subnational governments. Conservation policies are mainly implemented at national and subnational levels. But, in Mediterranean countries the current national legislation on the protection of fauna and flora mainly derives from the transposition of EU legislation. National governments apply the provisions set forth under binding international conventions on nature conservation.

Among the 28 European countries that provided a threatened species list, 19 included spiders in national or subnational legislation (Figures 2 and 5, Table 3). These consider the threat status of a species when designating conservation priorities, planning conservation efforts or allocating conservation funds.

Most acts of law which incorporate spiders among nationally protected fauna are issued in Central-Eastern European countries. Austria has the highest number of spiders under legal protection, with 111 species, followed by Slovakia, Serbia and Ukraine, all of them listing 17 spider species, and then by Hungary with 16 species, Croatia with 12, and Poland with nine.

On one hand, Northern European countries have a very low percentage of species protected, but the lowest percentage of threatened species, possibly in relation to the low degree of environmental pressures therein. On the other hand, in Mediterranean countries,

\section{Accepted manuscript}


few species are mentioned in national or subnational legislation, despite their higher values of spider diversity and the high level of pressure on local biodiversity.

The reasons behind this geographic pattern are not trivial. This could be related to the role of arachnologists in influencing local conservation policies. However, we failed to find a significant relation between the number of spider species listed in legal acts and the number of species assessed as threatened in regional Red Lists and Red Data Books. The same non-significant result was found when correlating the number of spider species listed in legal acts to the number of local arachnologists and experts on country basis (see Table C3 in Appendix C).

Socio-cultural aspects provide a more reliable explanation, in particular when considering local cultural values and the associated perception of wildlife. It is likely that different cultural backgrounds create variable levels of information on the subject of the environment and generate different perceptions about nature conservation. The availability of information on environmental issues may have strong implications for how individuals relate to the environment and perceive environmental policies, resulting in a greater influence in these areas and in related conservation actions. As illustrated in the European Commission report on the attitude of European citizens towards the environment (Eurobarometer, 2008), the best informed citizens are likely to live in the northern and western part of the $E U$, while those who tend to feel they lack information are likely to come from southern Europe and the new Member States. The media representation of spiders in Southern Europe does not help either (data from Italy; Mammola et al., 2020a). Accordingly, it seems likely that an enhanced awareness of wildlife promotes wildlife conservation even in a neglected group such as spiders.

In some countries a nature conservation economic value per specimen is also provided. In Hungary, this amounts to a monetary value from 5,000 forints to 10,000 forints (ca. 15-30 $€)$ depending on the species. Protected species in Slovakia are valued at $230 €$. These economic values refer to all listed species, whether alive or dead, or any part or derivative thereof. According to these economic values, whoever kills a specimen of the protected species may be subjected to the payment of the relative amount.

\section{SPIDER SPECIES OF CONSERVATION CONCERN IN EUROPE}

\section{Accepted manuscript}


Macrothele calpeiana (Figure 6) is the only spider protected at the European level, being listed both in the Bern Convention and in the EU Habitats Directive.

The appropriateness of legal protection for this species, as for many other invertebrates, has been called into question (Bellvert and Arnedo, 2016; Jiménez-Valverde et al., 2011; van Helsdingen, 1993; van Helsdingen and Decae, 1992), showing that the selection of species to be protected by environmental legislation at the European scale can be subject to bias (Cardoso, 2011; Leandro et al., 2017).

The rationale underlying the protection of $M$. calpeiana derived fundamentally from knowledge available at the time (Snazell, 1986; Snazell and Allison, 1989), which described both the species and its habitat as threatened. This knowledge has since developed considerably as a result of new and extensive research, which was very likely catalysed by its protected status, and thus consequently revealed a different conservation status.

In addition, M. calpeiana is, among spiders, one of those species which better complies with the aesthetic standards that seem to be preferred for a species to be eligible for protection (Collins and Wells, 1987), as the species is highly recognisable and easily identified and detected by the general public. In general, protected invertebrates are significantly bigger than the average invertebrate size (see Leandro et al., 2017), and the fact that $M$. calpeiana is the largest spider in Europe is a relevant factor.

As for many other invertebrates listed in Habitats Directive, the inclusion of $M$. calpeiana does not accurately reflect whether its protection is actually necessary.

\section{IUCN red listed spiders}

In the IUCN Global Red List of threatened species, only eight native European spiders currently appear (IUCN, 2021). This scant number explains to some extent the existing under-representation of spiders in the international conservation tools, and indicates a substantial disparity between groups. The number of species in the global IUCN Red List is highly biased in favor of the best-known and more charismatic animals, notably vertebrates, and, amongst invertebrates, Odonata, Lepidoptera and Orthoptera (See Figure C1).

\section{Accepted manuscript}


Taxonomic bias in biodiversity conservation has been widely recognized (Cardoso et al., 2011; Donaldson et al., 2016; Leandro et al., 2017; Leather, 2013; Mammides, 2019; Titley et al., 2017), and is mainly due to data deficiencies and technical limitations. However, this unbalanced consideration has deep implications for scientific research and conservation priorities towards spiders, suggesting a compelling need for more evaluations of the conservation status of such species.

Overall, at the national level, 55 spiders in Europe were assessed as Regionally Extinct (or comparable categories) from eight different countries. Among them, only one species, the linyphiid Agyneta decora (O. Pickard-Cambridge 1871) is considered extinct in two countries, the Czech Republic and Slovakia.

In the European countries considered, 714 spider species (17\%) have been identified as threatened with extinction in national Red Lists, and listed in the IUCN categories Vulnerable (VU), Endangered (EN) and Critically Endangered (CR) or other comparable categories used by other classification systems. In addition, 30 species appear in the threatened categories of national Red Lists or Red Data Books from five or more European countries (Table 4). Many of the 714 species are habitat specialists or have highly restricted ranges (324 species occur in only one country, and 202 species at most in two countries) (Nentwig et al., 2020).

Despite this, only 178 European spiders have full legal protection across the European countries (Figure 5) and only 17 species feature in conservation acts of two or more countries (Table 5). Here we present information on the most frequently mentioned spider species in the European conservation tools.

\section{Dolomedes plantarius}

Dolomedes plantarius (Figure 6) is the spider species featuring the most in Red Lists and protection programmes across Europe. It has been assessed by 13 out of 20 European countries in national Red Lists and Red Data Books and features as threatened in seven of them (Table 4). Nine European countries consider D. plantarius in acts of law, protecting the species and its habitat (Table 5). The extent of consideration given to this species is related in part to its wide distribution, and especially to the large-scale degradation and loss of its wetland habitat (Duffey, 1995; Leroy et al., 2013, 2014; van Helsdingen, 1993). This habitat has been increasingly subjected to alteration due to land-use intensification, changes in 21

\section{Accepted manuscript}


hydrology, physical modification, eutrophication, and pollution (Junk et al., 2013; Smith, 2000). Wetlands are recognized as being of paramount importance for biodiversity and as a preferential target of conservation efforts, mainly due to the number of threatened and charismatic taxa (Finlayson et al., 2019; Geijzendorffer et al., 2018).

\section{Argyroneta aquatica}

Argyroneta aquatica (Figure 6) also inhabits wetlands and has benefited both from this conservation interest and from interest in its unique biology, since it is the only almost wholly aquatic spider species (Seymour and Hetz, 2011). It has been assessed by the national Red Lists of 11 countries, six of which consider it to be threatened (Table 4), and is included in the conservation legislation of seven countries (Table 5).

\section{Marpissa radiata}

Marpissa radiata (Grube, 1859) (Figure 6) is another species strictly associated with wetlands. It figures in national Red Lists and Red Data Books of nine countries, seven of which consider it vulnerable (Table 4). However, this species is protected only in Austria, in the 59th Regulation of 2015 of Carinthia (LGBI. Nr. 59/2015). Even if widespread in Europe, this species is rather rare, being confined to wet habitats, and is considered threatened in most of its distribution range as a consequence of wetland decline.

\section{Eresus spiders}

Spiders of the genus Eresus (Figure 6) often feature in European conservation tools. Currently, 12 species are known to occur in Europe (Nentwig et al., 2020) but only three of them, E. kollari, E. sandaliatus, and E. moravicus Řezáč 2008, feature in inventories on threatened species or in conservation acts. These species were formerly lumped into one morphospecies and have been treated as such in most conservation tools, but recent taxonomic revisions have shown three species are involved (Řezáč et al., 2008; Miller et al., 2012). Eresus kollari is one of the most considered spider species in conservation acts of law, figuring as legally protected in seven European countries (Table 5). In addition, it occurs in the national Red Lists of seven countries, and is considered threatened in five of them (Table 4). Eresus sandaliatus is considered in five countries, and is protected in four (Tables 4, 5). Eresus spiders are mainly threatened by habitat loss and degradation due to anthropogenic pressure, and by large-scale fragmentation of their habitats. Recently, they

\section{Accepted manuscript}


have become flagship species for the conservation of relic rocky steppes in several central European countries (Řezáč et al., 2008), and their habitat requirements have been studied in detail (Řezáč et al., 2007, 2018; Řezáč and Heneberg, 2014, 2019). The fact that these species are amongst the most beautiful spiders in Europe (Miller et al., 2012)—which also makes them the most collectable European spiders, also present in the pet trade-may have strongly influenced their inclusion in conservation tools and their consideration as species of conservation concern.

\section{Atypus spiders}

The European species of the genus Atypus (Atypidae) (Figure 6) are well covered by conservation measures (Tables 4, 5). Atypus affinis Eichwald, 1830 has been assessed by six national Red Lists, is considered threatened by three of them and figures in the conservation legislation of four European countries. Atypus muralis Bertkau, 1890 is both listed as threatened, and protected, in five countries. Atypus piceus (Sulzer, 1776) is listed as threatened in three countries and is protected by law in four countries. These spiders mainly occur in open xerothermic grasslands and are threatened by changes in the management of their habitats, including intensive grazing or the overgrowth of grass and woody plants (Řezáč et al. 2007; Řezáč and Heneberg 2014).

\section{PERSPECTIVES AND CONCLUSIONS}

\section{Ongoing conservation actions in Europe}

At an international level, the increased adoption of tools compliant with the IUCN Red List has added to the number of assessments of spider species. These tools aim to increase the number of evaluations in order to obtain an indicator that reliably represents the overall conservation status of this group (Shirey et al., 2019). However, changes in the overall conservation status of European spiders are still hard to define, due to a lack of both comprehensive knowledge and monitoring data for individual species. To reliably determine trends, it would be necessary to obtain solid baseline knowledge of the current conservation status of species and to perform regular and timely assessments of these species over time, as recently recommended by Harvey et al. (2020) in the roadmap for insect conservation and recovery.

\section{Accepted manuscript}


In this regard, the conservation profiles of a sample of 200 species - including several European species - randomly selected from the spider Tree of Life, has been evaluated (Seppälä et al., 2018a, 2018b, 2018c, 2018d). These contributions aim to create a baseline for comparison with a future spider Sampled Red List Index which will ideally operate as a randomized indicator of the changing state of a taxonomic group based on the IUCN Red List criteria (Baillie et al., 2008).

In addition, new standardized sampling protocols for megadiverse taxa have been developed (Borges et al., 2018; Cardoso, 2008; 2009). These aim to facilitate biodiversity assessment and monitoring, and have clear and direct applications in spider conservation. Other approaches suitable for terrestrial invertebrates may be difficult to apply for spiders. For instance, involving citizen scientists in spider surveys may be very useful by way of improving a general lack of knowledge of the group (see Hart et al., 2018 and Wang et al. 2018 for successful examples), and ultimately developing effective conservation strategies (Devictor et al., 2018). However, given that for many species, an expert-based examination of sexual characters is required, this approach may be of limited use.

Our understanding is that several species are currently under regional assessment in different parts of Europe. For example, a recent study confirmed the status of Macrothele cretica as Vulnerable since its distribution is restricted to western Crete and its habitat is threatened, putting it at risk of extinction (Chatzaki and Komnenov, 2019).

Similar studies focusing on Dolomedes plantarius in Italy (Milano et al., 2018), on the cavedwelling steno-endemic Histopona palaeolithica Brignoli 1971 (Agelenidae) (Mammola et al., 2019a), on the endemic alpine Pimoa delphinica Mammola, Hormiga \& Isaia 2016 (Pimoidae) (Mammola et al., 2017a), and on cave-dwelling species of Troglohyphantes in the Western Alps (Mammola et al., 2018b) underline the need for more detailed knowledge of their status in order to provide new assessments of extinction risk. Concerning Vesubia jugorum, a five-year monitoring program led by the University of Turin and the Natural Parks of Mercantour (France) and Alpi Marittime (Italy) began in 2019, aiming to monitor the health of local populations through a trait-based approach (see Mammola et al., 2019b).

In Great Britain, all spiders listed as Species of Principal Importance under the NERC Act (2006) in England, and equivalents acts in Wales, Scotland and Northern Ireland, have action plans prepared for their conservation at national and often also at regional levels. For

\section{Accepted manuscript}


many of these rare species, the primary action is still to improve understanding of their status and ecology to inform future conservation action. For some species the plans and conservation actions are well-developed. Eresus sandaliatus and Dolomedes plantarius are both subjects of long-term monitoring and translocation programmes. Translocations of $E$. sandaliatus began in 2003 and have increased the number of locations from one to around 17. Translocations of $D$. plantarius, begun in 2010 (Smith et al., 2013), have increased the number of sustainable populations from three to seven. Both translocation programmes followed IUCN guidelines (IUCN/SSC, 2013). They have substantially reduced the threat of extinction of these species in Britain and have been used to test the development of the IUCN Green List (Akçakaya et al., 2018) for assessing conservation recovery.

In Sweden, two spiders are included in national action plans, namely Eresus sandaliatus and Cheiracanthium pennyi O. Pickard-Cambridge, 1873; the latter is considered in actions aiming to restore sand dune habitats.

Several projects aiming to create inventories of threatened spiders or to update the existing ones, are currently in progress in European countries (See Table C2 in Appendix C).

\section{Concluding remarks}

Regional Red Lists and Red Data Books are the most reliable source of information on the current conservation status of spiders in Europe. Accurate evaluations of the conservation status of species represent a tool of paramount importance in conservation efforts focussing on threatened spiders. These tools provide quantitative data for informing national conservation priorities and for developing species-based management strategies. The IUCN developed a system of criteria aiming to enhance the objectivity and comparability of these Red Lists. Even though these lists do not confer any legal protection to the species assessed, they inform and influence conservation policies and legislation.

Unfortunately, the availability of Red Lists on spiders is far from homogeneous across European countries, many of which lack regional inventories or have outdated ones. This means that there are large knowledge gaps in the conservation status of the European spider fauna. For many species, data is incomplete or out-of-date, resulting in assessments based on poor quality information, and thus excluding potential candidate species from

\section{Accepted manuscript}


threatened species lists. To gain a better indication of the current status of a national fauna, data needs to be analysed and digitised, so that research priorities for species conservation may be more efficient and timely.

A major shortfall is the lack of monitoring of spider populations, which is essential to assess the long-term dynamics of species and their possible decline. Documenting changes in populations provides key information for assessing the conservation status of a species. Monitoring helps to provide baselines against which changes can be evaluated, and to understand the population dynamics of species and how they can change in response to environmental disturbance. Comprehensive and reliable population trends are not available for most European spider species. As a consequence, spider species are very rarely assessed based on population size (Criteria A, C and D) and most of the available assessments are based on species' geographic range (Criterion B). In turn, species with restricted distributions (endemic) are most frequently assessed, whilst information on declines in more common species is lacking. An exception is the Amber List (Harvey et al., 2017), recently adopted in Great Britain to highlight common species appeared to have undergone substantial decline, and which therefore need more frequent and detailed assessment (for details, see Appendix B). It is one possible approach to identifying and initiating actions for rapidly declining species that do not yet qualify for threatened status. Better monitoring of spider populations in Europe is urgently needed in order to understand and assess their potential risk of extinction.

This patchy understanding of the conservation status of spiders in Europe, together with the generally scant consideration given to this group, represents a considerable obstacle to the inclusion of spiders in conservation legislation and conservation planning.

Some studies (e.g. Chichorro et al., 2020) suggest using, in the absence of reliable data on species distribution and population trends, species traits as predictors of extinction risk. Using traits could help to reduce the knowledge gap, allowing prioritization of future research, monitoring and conservation efforts even for largely unknown and neglected taxonomic groups (Lowe et al., 2020). The recent development of the World Arachnid Trait database is a major step towards achieving this goal (Pekár et al., 2021).

In spite of the recognised ecological role of this group, and the scientific efforts to assess the conservation status of spider species and highlight the extent to which they are 
threatened, spiders are rarely included in legislation and funding programs devoted to conservation. For example, given that virtually no spider species are included in the Habitats Directive, the conservation of spiders as a group receives no EU financial investment through the LIFE program (Mammola et al., 2020b).

To date, almost one third of the European spiders have been assessed in at least one European country (1,552 out of 4,154 total species occurring). Among these, almost half are considered as threatened (714), and only very few species benefit from legal protection (178) in at least one country. The existing knowledge of the risk of extinction of many European spiders is not properly reflected in effective conservation measures. Although the main aim of the Red Lists should be assessing the risk of extinction of the species rather than determining conservation priorities (Mace et al., 2008), they are widely used to identify those species for which it is urgent to implement effective conservation actions. However, for spiders, assessments of conservation status have been seldom conflated in calls for species protection. This suggests that these lists are not effective in influencing national species conservation policies, and exposes the lack of a direct link between lists of threatened spider species and legislation.

Conversely, some of the spiders listed in legislation are far from being threatened. This is the case for Macrothele calpeiana (Figure 6), for which there is a substantial debate questioning the need for its protection.

This lack of connection between Red Lists and legal protection diminishes the usefulness and appropriateness of both tools in spider conservation.

The number of spider species, and especially the quality of data underlying the choice of species to protect, should be improved in legislation, both at the regional and international level. Accordingly, the appropriateness of the implementation of some European spiders in CITES should be evaluated. Because no native European spider is currently included in CITES, and as there is no quantitative data on the existing trade in spiders from Europe, more studies should verify which species might be harmed by trade, and its potential impact should be assessed.

To date, the protection of large areas of suitable habitat has been addressed as the most effective approach to spider conservation (Branco and Cardoso, 2020). Indeed, the protection of sites hosting key habitats plays a crucial role in effective conservation 27

\section{Accepted manuscript}


strategies (Coetzee et al., 2014; Geldmann et al., 2013; Gray et al., 2016; Harvey et al., 2020). The Natura 2000 network of protected areas accounts for 18\% of the EU's land territory (European Environmental Agency, 2012). Even considering ecological corridors connecting these areas, which may mitigate large-scale future threats (see for example Leroy et al., 2014), the percentage of protected areas is far from adequate to conserve spider diversity. Spider species within these habitats will presumably benefit but a large proportion of threatened species are poorly covered by the Natura 2000 network, and no priority areas specifically for conserving spiders exist. The new 2030 Biodiversity Strategy intends to transform at least 30\% of the European territory into managed protected areas. This plan is ambitious, but absolutely necessary to halt the loss of spider diversity. The current threats to spiders in Europe indicate the need to expand existing protected areas and to designate new ones in order to include more spider species that need protection (Mammola et al., 2020b). With the limited resources available for the protection of biodiversity, areas hosting high concentrations of endemic and threatened spider species should be considered clear priorities for conservation. 


\section{Declaration of competing interest}

We declare that there are no conflicts of interest regarding this research and manuscript.

On the behalf of the authors,

Marco ISAIA

and

Filippo MILANO, Pedro CARDOSO, BLICK Theo, CHATZAKI Maria, FUKUSHIMA

Caroline Sayuri, GAJDOŠ Peter, GIBBONS Alastair T, MACíAS-HERNÁNDEZ Nuria,

MAMMOLA Stefano, NENTWIG Wolfgang, NOLAN Myles, PÉTILLON Julien,

POLCHANINOVA Nina, ŘEZÁČ Milan, SANDSTRÖM Jonas, SMITH Helen, WIŚNIEWSKI

Konrad

\section{Acknowledgements}

We are grateful to all spider experts who helped us in finding in- formation about spider conservation in their home- and/or nearby- countries: Ingi Agnarsson (Iceland), Oleg Aleksandrowicz (Belarus), Sandra Åström (Norway), Marija Biteniekytè (Lithuania), Rop Bosmans (Belgium), Inese Cera (Latvia), Samuel Danflous (France), Wouter Dekonick (Belgium), Christo Deltshev (Bulgaria), Jason Dunlop (UK and Germany), Mert Elverici (Turkey), Alain Frantz (Luxembourg), Gordana Grbić (Serbia), Davide Guglielmo (Italy), Frederik Hendrickx (Belgium), Vladislav Ivanov (Belarus), Luka Katušić (Croatia), Marjan Komnenov (North Macedonia), Seppo Koponen (Finland), Torbjörn Kronestedt (Sweden), Matjas Kuntner (Slovenia), Jorg Lambrechts (Belgium), Sylvain Lecigne (France), Boris Leroy (France), Jørgen Lissner (Denmark), Dirk Maes (Belgium), Adam Mantell (United Kingdom), Yuri Marusik (Russia), Mart Meriste (Estonia), Xavier Mestdagh (Luxembourg), Norbert Milasowszky (Austria), Marija Miličić (Serbia), Jesper Erenskjold Moeslund (Denmark), Lorenzo Pancotti (Italy), Paolo Pantini (Italy), Igor Popov (Russia), Christine Rollard (France), Nikolaj Scharff (Denmark), Tamás Szűts (Hungary), Marco Tolve (Italy), Julien Touroult (France), István Urák (Romania), Peter van Helsdingen (Netherlands), Koen Van Keer (Belgium), Blerina Vrenozi (Albania), Marek Żabka (Poland) and Klaus Peter Zulka (Austria).

We are grateful to Emanuele Biggi, Tiziano D'Elia and Janusz Kupryjanowicz for sharing their photos of spiders (see caption of Fig. 6).

\section{Accepted manuscript}


FM and MI conceived the study. FM and MI contributed equally to the work. AG, MN and HS proofread English and provided substantial ameliorations to the original text. FM retrieved data on legal acts and Red Lists across Europe, built the species database, and wrote the first draft. MI suggested the general line of enquiry, coordinated the group of contributors, created maps, and provided amendments to the first draft and to the final revised version. TB provided information on Austria, Germany and Switzerland. PC provided information on Finland, Portugal and Macaronesia and contributed substantially to the organization of the text. MC provided information on Greece. CSF provided information on CITES and spider trading. PG provided information on Slovakia and other Eastern European countries. AG provided information on Great Britain. SH provided valuable contribution to different sections of the manuscript during the first round of revision. $\mathrm{NMH}$ provided information on Spain. SM revised different sections of the manuscript, improved the revised version and prepared barcharts. WN provided information on spider distribution in Europe and ensured the collaboration with Araneae - Spider of Europe network. MN provided information on Great Britain and Ireland. JP provided information on France. NP provided information on Ukraine. MR provided information on the Czech Republic. JS provided information on Sweden. HS pro- vided information on Great Britain and contributed significantly to the final version of the text. $\mathrm{KW}$ provided information on Poland and other Eastern European countries. All authors contributed significantly to the writing of the manuscript by means of comments and additions to the text.

Data repository statement

Our data are stored within World Arachnid Trait database (Milano et al., 2021a, b) at https://spidertraits.sci.muni.cz/datasets/160 and https://spidertraits.sci.muni.cz/datasets/162. 


\section{REFERENCES}

Akçakaya, H.R., Bennett, E.L., Brooks, T.M., Grace, M.K., Heath, A., Hedges, S., HiltonTaylor, C., Hoffmann, M., Keith, D.A., Long, B., Mallon, D.P., Meijaard, E., Milner-Gulland, E.J., Rodrigues, A.S.L., Rodriguez, J.P., Stephenson, P.J., Stuart, S.N., Young R.P., 2018. Quantifying species recovery and conservation success to develop an IUCN Green List of Species. Conserv. Biol. 32(5), 1128-1138. https://doi.org/10.1111/cobi.13112

Akimov, I.A. (Ed.), 2009. Red Book of Ukraine. Animal world., Globconsulting, Kyiv.

Asbirk, S., Søgaard, M. (Eds.), 1991. Rødliste 90. Miljøministeriet, Copenhagen.

Baillie, J.E.M., Collen, B., Amin, R., Akçakaya, H.R., Butchart, S.H.M., Brummitt, N.A., Meagher, T.R., Ram, M., Hilton-Taylor, C., Mace, G.M., 2008. Toward monitoring global biodiversity. Conserv. Lett. 1, 18-26. https://doi.org/10.1111/j.1755-263X.2008.00009.x.

Barea-Azcón, J.M., Ballesteros-Duperón, E., Moreno, D. (Eds.), 2008. Libro Rojo de los Invertebrados de Andalucía. 4 Tomos. Consejería de Medio Ambiente, Junta de Andalucía, Sevilla.

Bellvert, A., Arnedo, M.A., 2016. Threatened or threatening? Evidence for independent introductions of Macrothele calpeiana (Walckenaer, 1805) (Araneae: Hexathelidae) and first observation of reproduction outside its natural distribution range. Arachnology 17(3), 137141. https://doi.org/10.13156/arac.2006.17.3.137.

Birkhofer, K., Gossner, M.M., Diekötter, T., Drees, C., Ferlian, O., Maraun, M., Scheu, S., Weisser, W.W., Wolters, V., Wurst, S., Zaitsev, A.S., Smith, H.G., 2017. Land-use type and intensity differentially filter traits in above-and below-ground arthropod communities. J. Anim. Ecol. 86(3), 511-520. https://doi.org/10.1111/1365-2656.12641.

Blab, J., Nowak, E., Trautmann, W., Sukopp, H. (Eds.), 1984. Rote Liste der gefährdeten Tiere und Pflanzen in der Bundesrepublik Deutschland. Naturschutz aktuell, Greven (Kilda).

Blick, T., Finch, O.-D., Harms, K.H., Kiechle, J., Kielhorn, K.-H., Kreuels, M., Malten, A., Martin, D., Muster, C., Nährig, D., Platen, R., Rödel, I., Scheidler, M., Staudt, A., Stumpf, H., Tolke, D., 2016. Rote Liste und Gesamtartenliste der Spinnen (Arachnida: Araneae) Deutschlands. Naturschutz und Biologische Vielfalt 70(4), 383-510.

\section{Accepted manuscript}


Blick, T., Scheidler, M., 2004. Rote Liste gefährdeter Spinnen (Arachnida: Araneae) Bayerns. In: Voith, J. (Ed.), Rote Liste gefährdeter Tiere Bayerns. Augsburg (Landesamt für Umweltschutz). Schriftenreihe Bayerisches Landesamt für Umweltschutz 166, 308-321.

Borges, P.A.V., Cardoso, P., Kreft, H., Whittaker, R.J., Fattorini, S., Emerson, B.C., Gil, A., Gillespie, R.G., Matthews, T.J., Santos, A.M., Steinbauer, M.J., Thébaud, C., Ah-Peng, C., Amorim, I.R., Aranda, S.C., Arroz, A.M., Azevedo, J.M.N., Boieiro, M., Borda-de-Água, L., Carvalho, J.C., Elias, R.B., Fernández-Palacios, J.M., Florencio, M., González-Mancebo, J.M., Heaney, L.R., Hortal, J., Kuefer, C., Lequette, B., Martín-Esquivel, J.L., López, H., Lamelas-López, L., Marcelino, J., Nunes, R., Oromí, P., Patiño, J., Pérez, A.J., Rego, C., Ribeiro, S.P., Rigal, F., Rodrigues, P., Rominger, A.J., Santos-Reis, M., Schaefer, H., Sérgio, C., Serrano, A.R.M., Sim-Sim, M., Stephenson, P.J., Soares, A.O., Strasberg, D., Vanderporten, A., Vieira, V., Gabriel, R., 2018. A Global Island Monitoring Scheme (GIMS) for the long-term coordinated survey and monitoring of forest biota across islands. Biodivers. Conserv. 27, 2567-2586. https://doi.org/10.1007/s10531-018-1553-7

Branco, V.V., Cardoso, P., 2020. An expert-based assessment of global threats and conservation measures for spiders. Glob. Ecol. Conserv. https://doi.org/10.1016/j.gecco.2020.e01290

Branco, V.V., Henriques, S., Rego, C., Cardoso, P., 2019. Species conservation profiles of spiders (Araneae) endemic to mainland Portugal. Biodivers. Data J. 7: e39315. https://doi.org/10.3897/BDJ.7.e39315.

Bratton, J.H., 1991. British Red Data Books: 3, Invertebrates other than insects. Joint Nature Conservation Committee, Peterborough.

Bruun, L.D., Lissner, J., 2019. Spiders. In: Moeslund, J.E., Nygaard, B., Ejrnæs, R., Bell, N., Bruun, L.D., Bygebjerg, R., Carl, H., Damgaard, J., Dylmer, E., Elmeros, M., Flensted, K., Fog, K., Goldberg, I., Gønget, H., Helsing, F., Holmen, M., Jørum, P., Lissner, J., Læsøe, T., Madsen, H.B., Misser, J., Møller, P.R., Nielsen, O.F., Olsen, K., Sterup, J., Søchting, U., Wiberg-Larsen, P., Wind, P. (Eds.), The Danish Red List 2019. Aarhus University, DCE National Center for Environment and Energy. redlist.au.dk. 
Buchar, J., 1992. Pavoukovci (Arachnida), pp. 39-53. In: Škapec, L. (Ed.), Červená kniha ohrožených a vzácných druhů rostlin a živočichů ČSFR, 3.díl. Bezobratlí [Czechoslovak Red Data Book], Príroda, Bratislava.

Buchar, J., Růžička, V., 2002. Catalogue of spiders of the Czech Republic, Peres Praha.

Buchholz, S., Hartmann, V., Kreuels, M., 2011. Rote Liste und Artenverzeichnis der Webspinnen - Araneae - in Nordrhein-Westfalen. 3. Fassung, Stand August 2010. In: Landesamt für Natur, Umwelt und Verbraucherschutz Nordrhein-Westfalen (LANUV) (Hrsg.), Rote Liste der gefährdeten Pflanzen, Pilze und Tiere in Nordrhein-Westfalen, 4. Fassung, Band 2 - Tiere. LANUV-Fachbericht 36. Duisburg (WAZ-Druck), 567-613.

Cálix, M., Alexander, K.N.A., Nieto, A., Dodelin, B., Soldati, F., Telnov, D., VazquezAlbalate, X., Aleksandrowicz, O., Audisio, P., Istrate, P., Jansson, N., Legakis, A., Liberto, A., Makris, C., Merkl, O., Mugerwa Pettersson, R., Schlaghamersky, J., Bologna, M.A., Brustel, H., Buse, J., Novák, V., Purchart, L., 2018. European Red List of Saproxylic Beetles. Brussels, Belgium: IUCN.

Cardoso, P., 2008. Biodiversity and conservation of Iberian spiders: past, present and future. Boletín de la SEA 42, 487-492.

Cardoso, P., 2009. Standardization and optimization of arthropod inventories - the case of Iberian spiders. Biodivers. Conserv. 18(14), 3949-3962. https://doi.org/10.1007/s10531009-9690-7

Cardoso, P., 2010. Anapistula ataecina. The IUCN Red List of Threatened Species 2010: e.T176265A7207415. https://dx.doi.org/10.2305/IUCN.UK.2010-

2.RLTS.T176265A7207415.en (accessed 27 November 2019).

Cardoso, P., 2011. Habitats Directive species lists: urgent need of revision. Insect Conserv. Divers. 5, 169-174. https://doi.org/10.1111/j.1752-4598.2011.00140.x.

Cardoso, P., Barton, P., Birkhofer, K., Chichorro, F., Deacon, C., Fartmann, T., Fukushima, C.S., Gaigher, R., Habel, J.C., Hallmann, C.A., Hill, M.J., Hochkirch, A., Kwak, M., Mammola, S., Noriega, J.A., Orfinger, A.B., Pedraza, F., Pryke, J.S., Roque, F., Settele, J., Simaika, J.P., Stork, N.E., Suhling, F., Vorster, C., Samways, M.J., 2020. Scientists' warning 
to humanity on insect extinctions. Biol. Conserv. 242, 108426. https://doi.org/10.1016/j.biocon.2020.108426.

Cardoso, P., Borges, P.A.V., Triantis, K.A., Ferrández, M.A., Martín, J.L., 2012. The underrepresentation and misrepresentation of invertebrates in the IUCN Red List. Biol. Conserv. 149, 147-148. https://doi.org/10.1016/j.biocon.2012.02.011.

Cardoso, P., Crespo, L., Silva, I., Borges, P.A.V., Boiero, M., 2017. Species conservation profiles of endemic spiders (Araneae) from Madeira and Selvagens archipelagos, Portugal. Biodivers. Data J. 5: e20810. https://doi.org/10.3897/BDJ.5.e20810.

Cardoso, P., Erwin, T.L., Borges, P.A.V., New, T.R., 2011. The seven impediments in invertebrate conservation and how to overcome them. Biol. Conserv. 144, 2647-2655. https://doi.org/10.1016/j.biocon.2011.07.024.

Cardoso, P., Gaspar, C., Pereira, L.C., Silva, I., Henriques, S.S., da Silva, R.R., Sousa, P., 2008. Assessing spider species richness and composition in Mediterranean cork oak forests. Acta Oecol. 33, 114-127. https://doi.org/10.1016/j.actao.2007.10.003.

Cardoso, P., Hilton-Taylor, C., 2015. Nothophantes horridus. The IUCN Red List of Threatened Species 2015:

e.T70560176A70560214. https://dx.doi.org/10.2305/IUCN.UK.2015-

1.RLTS.T70560176A70560214.en (downloaded 27 November 2019).

Cardoso, P., Scharff, N., 2009. First record of the spider family Symphytognathidae in Europe and description of Anapistula ataecina sp. n. (Araneae). Zootaxa 2246, 46-57. https://doi.org/10.5281/zenodo.190697.

Chatzaki, M., 2009. The Red Book of threatened and endangered animals of Greece: spiders. In: Legakis, A., Marangou, P., The Red Book of threatened and endangered animals of Greece. Hellenic Zoological Society, Athens.

Chatzaki, M., Komnenov, M., 2019. Description of a new Chaetopelma (Araneae, Theraphosidae) species from Crete and a re-description of Macrothele cretica Kulczyński, 1903 (Araneae, Hexathelidae). Zootaxa 4544(2), 269-284. https://doi.org/10.11646/zootaxa.4544.2.7. 
Chichorro, F., Urbano, F., Teixeira, D., Väre, H., Pinto, T., Brummitt, N., He, X., Hochkirch, A., Hyvönen, J., Kaila, L., Juslén, A., Cardoso P., 2020. Species traits predict extinction risk across the Tree of Life. bioRxiv, 2020.07.01.183053

CITES, 2020. Convention on International Trade in Endangered Species of wild fauna and flora. https://www.cites.org (accessed 11 February 2020).

Clark, J.A., May, R.M., 2002. Taxonomic bias in conservation research. Science 297(5579), 191-192. https://doi.org/10.1126/science.297.5579.191b.

Coddington, J.A., Agnarsson, I., Miller, J.A., Kuntner, M., Hormiga, G., 2009. Undersampling bias: the null hypothesis for singleton species in tropical arthropod surveys. J. Anim. Ecol. 78(3): 573-584. doi: 10.1111/j.1365-2656.2009.01525.x.

Coddington, J.A., Griswold, C.E., Davila, D.S., Peñaranda, E., Larcher, S.F., 1991. Designing and testing sampling protocols to estimate biodiversity in tropical ecosystems. In: Dudley, E.C. (Ed.), The unity of Evolutionary Biology: Proceedings of the fourth International Congress of Systematic and Evolutionary Biology, Dioscorides Press, Portland.

Coddington, J.A., Levi, H.W., 1991. Systematics and evolution of spiders (Araneae). Annu. Rev. Ecol. Syst. 22(1), 565-592. https://doi.org/10.1146/annurev.es.22.110191.003025.

Coetzee, B.W.T., Gaston, K.J., Chown, S.L., 2014. Local scale comparisons of biodiversity as a test for global protected area ecological performance: a meta-analysis. PLoS ONE 9, e105824. https://doi.org/10.1371/journal.pone.0105824

Collins, N.M., Wells, S.M., 1987. Invertebrates in need of special protection in Europe. European Committee for the Conservation of Nature and Natural Resources. Nature and Environment series, No. 35. Council of Europe, Strasbourg.

Cordillot, F., Klaus, G., 2011. Gefährdete Arten in der Schweiz. Synthese Rote Listen, Stand 2010. Bundesamt für Umwelt, Bern.

Corzo, G., Escoubas, P., 2003. Pharmacologically active spider peptide toxins. Cell. Mol. Life Sci. 60, 2409-2426. https://doi.org/10.1007/s00018-003-3108-6. 
Council of Europe, 1979. Convention on the Conservation of European Wildlife and Natural Habitats. Document 104, Strasbourg, France.

Cuttelod, A., García, N., Abdul Malak, D., Temple, H., Katariya, V. 2008. The Mediterranean: a biodiversity hotspot under threat. In: Vié, J.-C., Hilton-Taylor, C., Stuart, S.N. (Eds.). The 2008 Review of The IUCN Red List of Threatened Species. IUCN Gland, Switzerland.

Davies, T., Cowley, A., Bennie, J., Leyshon, C., Inger, R., Carter, H., Robinson, B., Duffy, J., Casalegno, S., Lambert, G., Gaston, K., 2018. Popular interest in vertebrates does not reflect extinction risk and is associated with bias in conservation investment. PLoS ONE 13(9), e0203694. https://doi.org/10.1371/journal.pone.0203694.

de Grammont, P.C., Cuarón, A.D., 2006. An evaluation of threatened species categorization systems used on the American continent. Conserv. Biol. 20(1), 14-27.

Devictor, V., Whittaker, R.J., Beltrame, C. 2010. Beyond scarcity: citizen science programmes as useful tools for conservation biogeography. Divers. Distrib. 16(3), 354-362. https://doi.org/10.1111/j.1472-4642.2009.00615.x

Donaldson, M.R., Burnett, N.J., Braun, D.C., Suski, C.D., Hinch, S.G., Cooke, S.J., Kerr, J.T., 2016. Taxonomic bias and international biodiversity conservation research. FACETS 1: 105-113. https://doi.org/10.1139/facets-2016-0011

DS/IRV (Deutsche Sektion des Internationalen Rats für Vogelschutz), 1971. Die in der Bundesrepublik Deutschland gefährdeten Vogelarten und der Erfolg von Schutzmaßnahmen. Berichte der Deutsche Sektion des Internationalen Rats für Vogelschutz 11, 31-37.

Duelli, P., 1994. Rote Listen der gefährdeten Tierarten der Schweiz. BUWAL, Bem.

Duffey, E., 1995. The distribution, status and habitats of Dolomedes fimbriatus (Clerck) and D. plantarius (Clerck) in Europe, 54-65. In: Ružicka, V. (Ed.), Proceedings of the $15^{\text {th }}$ European Colloquium of Arachnology. Institute of Entomology, Ceske Budejovice.

Dunlop, J.A., Penney, D., Jekel, D., 2018. A summary list of fossil spiders and their relatives. In: World Spider Catalog. Natural History Museum Bern. http://wsc.nmbe.ch, version 19.0 (accessed 30 November 2019). 
Ehnström, B., Gärdenfors, U., Lindelöw, Å., 1993. Rödlistade evertebrater i Sverige. Databanken för hotade arter, Uppsala.

Epstein, Y., 2013. Population based species management across legal boundaries: the Bern Convention, Habitats Directive and the Gray Wolf in Scandinavia. Georgetown International Environmental Law Review 25, 589-614.

European Environmental Agency, 2012. Protected areas in Europe: an overview. EEA Report N5/2012. EU, Luxembourg.

Finch, O.-D., 2004. Rote Liste der in Niedersachsen und Bremen gefährdeten Webspinnen (Araneae) mit Gesamtartenverzeichnis. Informationsdienst Naturschutz Niedersachsen, Supplement 5, 1-20.

Finlayson, C.M., Davies, G.T., Moomaw, W.R., Chmura, G.L., Natali, S.M., Perry, J.E., Sutton-Grier, A.E. 2019. The second warning to humanity-providing a context for wetland management and policy. Wetlands 39(1), 1-5. https://doi.org/10.1007/s13157-018-1064-z

Foelix, R.F., 2011. Biology of Spiders. $3^{\text {rd }}$ Edition. Oxford University Press, New York.

Farkač, J., Král, D., Škorpík, M. (Eds.), 2005. Červený seznam ohrožených druhů České republiky. Bezobratlí. List of threatened species in the Czech Republic. Invertebrates. Agentura ochrany prírody a krajiny ČR, Praha.

Fukushima, C., Mammola, S., Cardoso, P., 2020. Global wildlife trade permeates the Tree of Life. Biol. Conserv. 247, 108503. https://doi.org/10.1016/j.biocon.2020.108503

Gajdoš, P., Moscaliuc, L.A., Rozwałka, R., Hirna, A., Majkus, Z., Gubányi, A., Heltai, M.G., Svatoň, J., 2014. Red list of spiders (Araneae) of the Carpathian Mts., pp. 82-135. In: Kadlečík, J. (Ed.), Draft Carpathian red list of forest habitats and of species draft Carpathian list of invasive alien species, Štátna ochrana prírody Slovenskej republiky [State Nature Conservancy of the Slovak Republic], Banská Bystrica.

Gajdoš, P., Svatoň, J., 1994. The red list of spiders of Slovakia. C.R. XIVe Coll. eur. Arachnol. Catania 1993. Bollettino dell'Accademia Gioenia di Scienze Naturali 26(345), 115-133. 
Gajdoš, P., Svatoň, J., 2001. Červený (ekosozologický) zoznam pavúkov (Araneae) Slovenska. Red (Ecosozological) List of spiders (Araneae) of Slovakia. In: Baláž, D., Marhold, K., Urban, P. (Eds.), Červený zoznam rastlín a živočíchov Slovenska. Red List of plants and animals of Slovakia. Nature Conservation. Ochrana Prírody, ŠOP SR Banská Bystrica 20: 80-86.

Gajdoš, P., Svatoň, J., Sloboda, K., 1999. Katalóg pavúkov Slovenska. Catalogue of Slovakian Spiders. Ústav krajinnej ekológie SAV, Bratislava.

Gärdenfors, U., 2001. Classifying threatened species at national versus global levels. Trends Ecol. Evol. 16, 511-516. https://doi.org/10.1016/S0169-5347(01)02214-5

Geijzendorffer, I., Chazée, L., Gaget, E., Galewski, T., Guelmami, A., Perennou, C., Davidson, R., McInnes, R., 2018. Mediterranean wetlands outlook 2: Solutions for sustainable Mediterranean wetlands. Secretariat of the Ramsar Convention.

Geldmann, J., Barnes, M., Coad, L., Craigie, I.D., Hockings, M., Burgess, N.D., 2013. Effectiveness of terrestrial protected areas in reducing habitat loss and population declines. Biol. Conserv. 161, 230-238. https://doi.org/10.1016/j.biocon.2013.02.018

Gerlach, J., 2014. Hasarius adansoni. The IUCN Red List of Threatened Species 2014: e.T196248A2443143. https://dx.doi.org/10.2305/IUCN.UK.20141.RLTS.T196248A2443143.en (downloaded 27 November 2019).

Głowaciński, Z., Nowak, J. (Eds.), 2004. Polish Red Data Book of Animals: Invertebrates. Institute of Nature Conservation PAS. The A. Cieszkowski Agricultural University, Kraków Poznań. http://www.iop.krakow.pl/pckz/defaultf803.html?nazwa=default\&je=pl (accessed 13 February 2019).

Golemansky, V., Stoev, P., Dobrev, D., Beron, P., Zhivkov, M., Popov, A., Popov, V., Beschkov, V., Deltshev, C., Michev, T., Spassov, N. (Eds.), 2015. Red Data Book Republic of Bulgaria. Vol. 2 Animals. Bulgarian Academy of Sciences, Ministry of Environment and Waters of Bulgaria, Sofia.

Gray, C.L., Hill, S.L.L., Newbold, T., Hudson, L.N., Börger, L., Contu, S., Hoskins, A.J., Ferrier, S., Purvis, A., Scharlemann, J.P.W., 2016. Local biodiversity is higher inside than 
outside terrestrial protected areas worldwide. Nat. Commun. 7:12306 https://doi.org/10.1038/ncomms12306

Groppali, R., Priano, M., 1992. Invertebrati non troglobi minacciati della fauna Italiana. In: Pavan, M. (Ed.), Contributo per un "Libro rosso" della fauna e della flora minacciate in Italia. Istituto di Entomologia dell'Università di Pavia, Pavia, 183-424.

Groupe ornithologique et naturaliste du Nord - Pas-de-Calais (2018). Liste rouge des espèces menacées - Les Araignées du Nord et du Pas-de-Calais. Fascicule labellisé au titre du Patrimoine naturel des Hauts-de-France. Version 8-1-2019.

Hallmann, C.A., Sorg, M., Jongejans, E., Siepel, H., Hofland, N., Schwan, H., Stenmans, W., Müller, A., Sumser, H., Hörren, T., Goulson, D., de Kroon, H., 2017. More than 75 percent decline over 27 years in total flying insect biomass in protected areas. PLoS ONE 12(10), e0185809. https://doi.org/10.1371/journal. pone.0185809.

Harms, K.H., 1984. Rote Liste der Spinnen (Araneae). In: Blab, J., Nowak, E., Trautmann, W., Sukopp, H. (Eds.), Rote Liste der gefährdeten Tiere und Pflanzen in der Bundesrepublik Deutschland. 4. Aufl., Naturschutz aktuell, Greven (Kilda) 1, 123-126.

Hart, A.G., Nesbit, R., Goodenough, A.E. 2018. Spatiotemporal Variation in House Spider Phenology at a National Scale Using Citizen Science. Arachnology 17(7), 331-334. https://doi.org/10.13156/arac.2017.17.7.331

Harvey, J.A., Heinen, R., Armbrecht, I., Basset, Y., Baxter-Gilbert, J.H., Bezemer, T.M., Böhm, M, Bommarco, R, Borges, P.A.V., Cardoso, P., Clausnitzer, V., Cornelisse, T., Crone, E.E., Dicke, M., Dijkstra, K.-D.B., Dyer, L., Ellers, J., Fartmann, T., Forister, M.L., Furlong, M.J., Garcia-Aguayo, A., Gerlach, J., Gols, R., Goulson, D., Habel, J.-C., Haddad, N.M., Hallmann, C.A., Henriques, S., Herberstein, M.E., Hochkirch, A., Hughes, A.C., Jepsen, S., Jones, T.H., Kaydan, B.M., Kleijn, D., Klein, A.-M., Latty, T., Leather, S.R., Lewis, S.M., Lister, B.C., Losey, J.E., Lowe, E.C., Macadam, C.R., Montoya-Lerma, J., Nagano, C.D., Ogan, S., Orr, M.C., Painting, C.J., Pham, T.-H., Potts, S.G., Rauf, A., Roslin, T.L., Samways, M.J., Sanchez-Bayo, F., Sar, S.A., Schultz, C.B., Soares, A.O., Thancharoen, A., Tscharntke, T., Tylianakis, J.M., Umbers, K.D.L., Vet, L.E.M., Visser, M.E., Vujic, A., Wagner, D.L., WallisDeVries, M.F., Westphal, C., White, T.E., Wilkins, V.L., Williams, P.H., Wyckhuys, K.A.G., Zhu, Z.-R., de Kroon, H. (2020). International scientists formulate a

\section{Accepted manuscript}


roadmap for insect conservation and recovery. Nat. Ecol. Evol. 4(2), 174-176. https://doi.org/10.1038/s41559-019-1079-8

Harvey, P., Davidson, M., Dawson, I., Fowles, A., Hitchcock, G., Lee, P., Merrett, P., Russell-Smith, A., Smith, H., 2017. A review of the scarce and threatened spiders (Araneae) of Great Britain: Species Status No. 22. NRW Evidence Report No. 11, Natural Resources Wales, Bangor.

Heim, M., Keerl, D., Scheibel, T., 2009. Spider silk: from soluble protein to extraordinary fiber. Angew. Chem. Int. Edit. 48(20), 3584-3596. https://doi.org/10.1002/anie.200803341.

Henriksen, S., Hilmo, O. (Eds.), 2015. Norsk rødliste for arter 2015. Artsdatabanken, Norge.

Hiebsch, H., Tolke, D., 1996. Rote Liste Weberknechte und Webspinnen. Freistaat Sachsen. Radebeul (Landesamt für Umwelt und Geologie). Materialien zu Naturschutz und Landschaftspflege.

Hyvärinen, E., Juslén, A., Kemppainen, E., Uddström, A., Liukko, U.-M. (Eds.), 2019. The 2019 Red List of Finnish Species. Ympäristöministeriö \& Suomen ympäristökeskus. Helsinki.

Ibrahimi, H., Gashi, A., Rexhepaj, D., Zhushi, F., Grapci-Kotori, L., Fehér, Z., Bino, T., Šerić Jelaska, L., Mesaroš, G., Théou, P., 2019. Red Book of Fauna of the Republic of Kosovo. Ministry of Environment and Spatial Planning \& Kosovo Institute for Nature Protection, Prishtina.

Isaia, M., Mammola, S., 2018. Vesubia jugorum. The IUCN Red List of Threatened Species 2018: e.T98700253A98700319. https://dx.doi.org/10.2305/IUCN.UK.2018-

1.RLTS.T98700253A98700319.en.

IUCN, 1994. IUCN Red List Categories: Version 2.3. IUCN Species Survival Commission, The World Conservation Union. IUCN, Gland, Switzerland.

IUCN, 2001. IUCN Red List Categories and Criteria: Version 3.1. IUCN Species Survival Commission. IUCN, Gland, Switzerland and Cambridge, UK. 
IUCN, 2003. Guidelines for Application of IUCN Criteria at Regional Levels. Version 3.0. IUCN Species Survival Commission. IUCN, Gland, Switzerland and Cambridge, UK.

IUCN, 2012a. Guidelines for Application of IUCN Red List Criteria at Regional and National Levels: Version 4.0. IUCN, Gland, Switzerland and Cambridge, UK.

IUCN, 2012b. IUCN Red List Categories and Criteria: Version 3.1. Second edition. IUCN, Gland, Switzerland and Cambridge, UK.

IUCN, 2021. The IUCN Red List of Threatened Species. Version 2020-3. http://www.iucnredlist.org

IUCN Conservation Monitoring Centre, 1986. 1986 IUCN Red List of Threatened Animals. Cambridge, UK.

IUCN/SSC, 2013. Guidelines for Reintroductions and Other Conservation Translocations. Version 1.0. Gland, Switzerland: IUCN Species Survival Commission, viiii + 57 pp.

Jedlička, L. (Ed.), 1995. Stav biologickej diverzity v Slovenskej republike. Štúdia projektu RVT 20-517-03: Ekosozologický výskum a manažment ohrozených druhov organizmov (deponovaná na MŽP SR). Bratislava.

Jiménez-Valverde, A., Decae, A.E., Arnedo, M.A., 2011. Environmental suitability of new reported localities of the funnel web spider Macrothele calpeiana: an assessment using potential distribution modelling with presence-only techniques. J. Biogeogr. 38(6), 12131223. https://doi.org/10.1111/j.1365-2699.2010.02465.x.

Jocqué, R., Alderweireldt, M., Dippenaar-Schoeman, A., 2013. Biodiversity. An African perspective. In: Penney, D. (Ed.), Spider Research in the $21^{\text {st }}$ Century trends and perspective. Siri Scientific Press, Manchester, pp. 18-57.

Junk, W.J., An, S., Finlayson, C.M., Gopal, B., Květ, J., Mitchell, S.A., Mitsch, J., Robarts, R.D., 2013. Current state of knowledge regarding the world's wetlands and their future under global climate change: a synthesis. Aquat. Sci. 75(1), 151-167. 
Juslén, A., Kuusinen, M., Muona, J., Siitonen, J., Toivonen, H., 2008. Research Programme of Deficiently Known and Threatened Forest Species 2003-2007 (PUTTE). Suomen Ympäristö 1, 1-146.

Kadlečík, J. (Ed.), 2014. Draft Carpathian red list of forest habitats and of species draft Carpathian list of invasive alien species. Štátna ochrana prírody Slovenskej republiky [State Nature Conservancy of the Slovak Republic], Banská Bystrica.

Kalkman, V.J., Boudot, J.P., Bernard, R., Conze, K.J., De Knijf, G., Dyatlova, E., Ferreira, S., Jović, M., Ott, J., Riservato, E., Sahlén, G., 2010. European Red List of Dragonflies. Publications Office of the European Union, Luxembourg.

Kielhorn, U., 2017. Rote Liste und Gesamtartenliste der Spinnen (Araneae) und Gesamtartenliste der Weberknechte (Opiliones) von Berlin. In: Rote Listen der gefährdeten Pflanzen, Pilze und Tiere von Berlin, Der Landesbeauftragte für Naturschutz und Landschaftspflege/Senatsverwaltung für Umwelt, Verkehr und Klimaschutz (Hrsg.). http://dx.doi.org/10.14279/depositonce-5859.

King, G.F., Hardy, M.C., 2013. Spider-venom peptides: structure, pharmacology, and potential for control of insect pests. Annu. Rev. Entomol. 58(1), 475-496. https://doi.org/10.1146/annurev-ento-120811-153650.

Ko, F.K., Wan, L.Y., 2018. Engineering properties of spider silk. In: Bunsell, A. (Eds.), Handbook of Properties of Textile and Technical Fibres. Woodhead Publishing, Sawston, Cambridge, pp. 185-220. https://doi.org/10.1016/B978-0-08-101272-7.00006-7

Komposch, C., Steinberger, K.-H., 1999. Rote Liste der Spinnen Kärntens (Arachnida: Araneae). In: Holzinger, W.E., Ildner, P.M., Rottenburg, T., Wieser, C. (Eds.), Rote Listen gefährdeter Tiere Kärntens, Naturschutz in Kärnten, Klagenfurt, 15, 567-618.

Koponen, S., 2008. Mapping the Spider Fauna (Araneae) of Finland. In: Makarov, S.E., Dimitrijević, R.N. (Eds.), Advances in Arachnology and Developmental Biology: papers dedicated to Professor Božidar Ćurčić. Institute of Zoology University of Belgrade, Serbia, 12, 349-354.

Lamoreux, J.F., Akçakaya, H.R., Bennun, L., Collar, N.J., Boitani, L., Brackett, D., Bräutigam, A., Brooks, T.M., da Fonseca, G.A.B., Mittermeier, R.A., Rylands, A.B., 42

\section{Accepted manuscript}


Gärdenfors, U., Hilton-Taylor, C., Mace, G., Stein, B.A., Stuart, S., 2003. Value of the IUCN red list. Trends Ecol. Evol. 18(5), 214-215. https://doi.org/10.1016/S0169-5347(03)000909.

Leandro, C., Jay-Robert, P., Vergnes, A., 2017. Bias and perspectives in insect conservation: a European scale analysis. Biol. Conserv. 215, 213-224. http://dx.doi.org/10.1016/j.biocon.2017.07.033

Leather, S.R., 2013. Institutional vertebratism hampers insect conservation generally; not just saproxylic beetle conservation. Anim. Conserv. 16, 379-380. https://doi.org/10.1111/acv.12068.

Lemke, M., Reinke, H.-D., Vahder, S., Irmler, U., 2013. Die Spinnen Schleswig-Holsteins. Rote Liste. In: Ministerium für Energiewende, Landwirtschaft, Umwelt und ländliche Räume des Landes Schleswig-Holstein: Rote Liste der in Schleswig-Holstein gefährdeten Pflanzen und Tiere. Flintbek (Landesamt für Landwirtschaft, Umwelt und ländliche Räume des Landes Schleswig-Holstein). LLUR SH, Natur - RL, 24.

Leroy, B., Bellard, C., Dubos, N., Colliot, A., Vasseur, M., Courtial, C., Bakkenes, M., Canard, A., Ysnel, F., 2014. Forecasted climate and land use changes, and protected areas: the contrasting case of spiders. Divers. Distrib. 20(6): 686-697. https://doi.org/10.1111/ddi.12191

Leroy, B., Paschetta, M., Canard, A., Bakkenes, M., Isaia, M., Ysnel, F., 2013. First assessment of effects of global change on threatened spiders: Potential impacts on Dolomedes plantarius (Clerck) and its conservation plans. Biol. Conserv. 161: 155-163. https://doi.org/10.1016/ j.biocon.2013.03.022.

Lowe, E.C., Wolff, J.O., Aceves-Aparicio, A., Birkhofer, K., Branco, V.V., Cardoso, P., Chichorro F., Fukushima, C.S., Gonçalves-Souza, T., Haddad, C.R., Isaia, M., Krehenwinkel, H., Audisio, T.L., Macías-Hernández, N., Malumbres-Olarte, J. Mammola, S., McLean, D.J., Michalko, R., Nentwig, W., Pekár, S., Pétillon, J., Privet, K., Scott, C., Uhl, G., Urbano-Tenorio, F., Wong, B.H., Herberstein, M.E. 2020. Towards establishment of a centralized spider traits database. J. Arachnol. 48(2), 103-109. https://doi.org/10.1636/01618202-48.2.103 
Mace, G.M., Collar, N.J., Gaston, K.J., HiltonTaylor, C., Akçakaya, H.R., Leader-Williams, N., Milner-Gulland, E.J., Stuart, S.N. 2008. Quantification of extinction risk: IUCN's system for classifying threatened species. Conserv. Biol. 22(6), 1424-1442. https://doi.org/10.111/j.1523-1739.2008.01044.x.

Maelfait, J.-P., Baert, L., Janssen, M., Alderweireldt, M., 1998. A Red list for the spiders of Flanders. Bulletin de l'Institut Royal des Sciences Naturelles de Belgique, Entomologie, 68, 131-142.

Maes, D., Verovnik, R., Wiemers, M., Brosens, D., Beshkov, S., Bonelli, S., Buszko, J., Cantú-Salazar, L., Cassar, L.-F., Collins, S, Dincă, V., Djuric, M., Dušej, G., Elven, H., Franeta, F., Garcia-Pereira, P., Geryak, Y., Goffart, P., Gór, A., Hiermann, U., Höttinger, H., Huemer, P., Jakšić, P., John, E., Kalivoda, H., Kati, V., Kirkland, P., Komac, B., Kőrösi, Á., Kulak, A., Kuussaari, M., L'Hoste, L., Lelo, S., Mestdagh, X., Micevski, N., Mihoci, I., Mihut, S., Monasterio-León, Y., Morgun, D.V., Munguira, M.L., Murray, T., Nielsen, P.S., Ólafsson, E., Õunap, E., Pamperis, L.N., Pavlíčko, A., Pettersson, L.B., Popov, S., Popović, M., Pöyry, J., Prentice, M., Reyserhove, L., Ryrholm, N., Šašić, M., Savenkov, N., Settele, J., Sielezniew, M., Sinev, S., Stefanescu, C., Švitra, G., Tammaru, T., Tiitsaar, A., Tzirkalli, E., Tzortzakaki, O., van Swaay, C., Viborg, A.L., Wynho, I., Zografou, K., Warren, M.S., 2019. Integrating national Red Lists for prioritising conservation actions for European butterflies. J. Insect Conserv. 23, 301-330. https://doi.org/10.1007/s10841-019-00127-z

Mammides, C., 2019. European Union's conservation efforts are taxonomically biased, Biodivers. Conserv. 28, 1291-1296. https://doi.org/10.1007/s10531-019-01725-8

Mammola, S., Cardoso, P., Ribera, C., Pavlek, M., Isaia, M., 2018a. A synthesis on cavedwelling spiders in Europe. J. Zool. Syst. Evol. Res. 56(3), 301-316. https://doi.org/10.1111/jzs.12201.

Mammola, S., Goodacre, S. L., Isaia, M., 2018b. Climate change may drive cave spiders to extinction. Ecography 41(1), 233-243. https://doi.org/10.1111/ecog.02902.

Mammola, S., Hormiga, G., Isaia, M., 2017a. Species conservation profile of the stenoendemic cave spider Pimoa delphinica (Araneae, Pimoidae) from the Varaita valley (NW-Italy). Biodivers. Data J. 5, e11509. https://doi.org/10.3897/BDJ.5.e11509. 
Mammola, S., Michalik, P., Hebets, E.A., Isaia, M., 2017b. Record breaking achievements by spiders and the scientists who study them. PeerJ 5, e3972. https://doi.org/10.7717/peerj.3972.

Mammola, S., Milano, F., Cardoso, P., Isaia, M., 2016. Species conservation profile of the alpine stenoendemic spider Vesubia jugorum (Araneae, Lycosidae) from the Maritime Alps. Biodivers. Data J. 4, e10527. https://doi.org/10.3897/BDJ.4.e10527.

Mammola, S., Milano, F., Isaia, M., 2019a. Taxonomy, ecology and conservation of the cave-dwelling spider Histopona palaeolithica, with the description of $H$. petrovi sp. nov. (Araneae: Agelenidae). J. Arachnol. 47(3), 317-325. https://doi.org/10.1636/0161-820247.3.317

Mammola, S., Milano, F., Vignal, M., Andrieu, J., Isaia, M., 2019b. Associations between habitat quality, body size and reproductive fitness in the alpine endemic spider Vesubia jugorum. Global Ecol. Biogeogr. 28(9), 1325-1335. https://doi.org/10.1111/geb.12935.

Mammola, S., Nanni, V., Pantini, P., Isaia, M., 2020a. Media framing of spiders may exacerbate arachnophobic sentiments. People Nat. 00, 1-13. https://doi.org/10.1002/pan3.10143

Mammola, S., Riccardi, N., Prié, V., Correia, R., Cardoso, P., Lopes-Lima, M., Sousa, R. 2020b. Towards a taxonomically unbiased EU Biodiversity Strategy for 2030. Roy. Soc. BBiol. Sci. 287(1940), 20202166. https://doi.org/10.1098/rspb.2020.2166

Martin, D., 2012. Rote Liste der Spinnen (Araneae) Mecklenburg-Vorpommern. Ministerium für Landschaft, Umwelt und Verbraucherschutz.

Mateleshko, O.Y., Potish, L.A. (Eds.), 2011. Red Book of the Ukrainian Carpathians. Animals. Karpaty, Uzhgorod.

McQueen, D.J., McLay, C.L., 1983. How does the intertidal spider Desis marina (Hector) remain under water for such a long time? New Zeal. J. Zool. 10(4), 383-391. https://doi.org/10.1080/03014223.1983.10423933.

Merrett, P., 1990. A review of the nationally notable spiders of Great Britain. NCC, Peterborough. 
Merrett, P., Russell-Smith, A., Harvey, P., 2014. A revised checklist of British spiders. Arachnology, 16(4), 134-144. https://doi.org/10.13156/arac.2014.16.4.134.

Michalko, R., Pekár, S., Dul'a, M., Entling, M.H., 2019. Global patterns in the biocontrol efficacy of spiders: A meta-analysis. Global Ecol. Biogeogr. 28(9), 1366-1378. https://doi.org/10.1111/geb.12927.

Milano, F., Blick, T., Chatzaki, M., Fukushima, C.S., Gajdoš, P., Gibbons, A.T., Henriques, S., Macías-Hernández, N., Mammola, S., Nentwig, W., Nolan, M., Pétillon, J., Polchaninova, N., Řezáč, M., Sandström, J., Smith, H., Wiśniewski, K., Cardoso, P., Isaia, M., $2021 a$. conservation_EU_2021-01-14. In: Pekár, S., Černecká, L'., Wolff, J., Mammola, S., Cardoso, P., Lowe, E., Fukushima, C.S., Birkhofer, K., Herberstein, M.E. (Eds.). The world arachnid trait database, available online at https://spidertraits.sci.muni.cz/datasets/160

Milano, F., Blick, T., Chatzaki, M., Fukushima, C.S., Gajdoš, P., Gibbons, A.T., Henriques, S., Macías-Hernández, N., Mammola, S., Nentwig, W., Nolan, M., Pétillon, J., Polchaninova, N., Řezáč, M., Sandström, J., Smith, H., Wiśniewski, K., Cardoso, P., Isaia, M., $2021 b$. EU_legal_protection. In: Pekár, S., Černecká, L', Wolff, J., Mammola, S., Cardoso, P., Lowe, E., Fukushima, C.S., Birkhofer, K., Herberstein, M.E. (Eds.). The world arachnid trait database, available online at https://spidertraits.sci.muni.cz/datasets/162

Milano, F., Pantini, P., Cavalcante, R., Isaia, M., 2018. Notes on the Italian distribution of Dolomedes plantarius (Clerck, 1757), species assessed for the IUCN Red List (Araneae: Pisauridae). Fragmenta entomologica 50(1), 69-74. https://doi.org/10.4081/fe.2018.285.

Miller, J.A., Griswold, C.E., Scharff, N., Řezáč, M., Szüts, T., 2012. The velvet spiders: an atlas of the Eresidae (Arachnida, Araneae). ZooKeys 195, 1-144. https://doi.org/10.3897/zookeys.195.2342.

Miller, R.M., Rodríguez, J.P., Aniskowicz-Fowler, T., Bambaradeniya, C., Boles, R., Eaton, M.A., Gärdenfors, U., Keller, V., Molur, S., Walker, S., Pollock, C., 2007. National threatened species listing based on IUCN criteria and regional guidelines: current status and future perspectives. Conserv. Biol. 21(3), 684-696. https://doi.org/10.1111/j.15231739.2007.00656.x. 
Nährig, D., Kiechle, J., Harms, K.H., 2003. Rote Liste der Webspinnen (Araneae) BadenWürttembergs. In: Nährig, D., Harms, K.H. Rote Listen und Checklisten der Spinnentiere Baden-Württembergs. Karlsruhe (Landesanstalt für Umweltschutz Baden-Württemberg). Fachdienst Naturschutz. Naturschutz-Praxis: Artenschutz 7, 7-162.

Nentwig, W. (Ed.), 2013. Spider ecophysiology. Springer Science \& Business Media, Berlin. Nentwig, W., Blick, T., Bosmans, R., Gloor, D., Hänggi, A., Kropf, C., 2020. araneae Version 03.2020. https://www.araneae.nmbe.ch. (accessed 11 March 2020). https://doi.org/10.24436/1

Nieto, A., Alexander, K.N.A., 2010. European red list of saproxylic beetles. Luxembourg: Publications Office of the European Union.

Nieto, A., Roberts, S.P.M., Kemp, J., Rasmont, P., Kuhlmann, M., García Criado, M., Biesmeijer, J.C., Bogusch, P., Dathe, H.H., De la Rúa, P., De Meulemeester, T., Dehon, M., Dewulf, A., Ortiz-Sánchez, F.J., Lhomme, P., Pauly, A., Potts, S.G., Praz, C., Quaranta, M., Radchenko, V.G., Scheuchl, E., Smit, J., Straka, J., Terzo, M., Tomozii, B., Window, J., Michez, D., 2014. European Red List of bees. Luxembourg: Publication Office of the European Union.

Noflatscher, M.-T., 1994. Lista Rossa dei Ragni (Arachnida: Araneidi) minacciati dell'Alto Adige. In: Lista Rossa delle specie animali minacciate in Alto Adige, Ripartizione tutela del paesaggio e della natura, Bolzano, 352-375.

Numa, C., van Swaay, C., Wynhoff, I., Wiemers, M., Barrios, V., Allen, D., Sayer, C., López Munguira, M., Balletto, E., Benyamini, D., Beshkov, S., Bonelli, S., Caruana, R., Dapporto, L., Franeta, F., Garcia-Pereira, P., Karaçetin, E., Katbeh-Bader, A., Maes, D., Micevski, N., Miller, R., Monteiro, E., Moulai, R., Nieto, A., Pamperis, L., Pe’er, G., Power, A., Šašić, M., Thompson, K., Tzirkalli, E., Verovnik, R., Warren, M., Welch, H., 2016. The status and distribution of Mediterranean butterflies. IUCN, Malaga, Spain.

Nyffeler, M., Birkhofer, K., 2017. An estimated 400-800 million tons of prey are annually killed by the global spider community. The Science of Nature 104(3-4), 30. https://doi.org/10.1007/s00114-017-1440-1. 
Ozimec, R., Bedek, J., Gottstein, S., Jalžić, B., Slapnik, R., Štamol, V., Bilandžija, H., Dražina, T., Kletečki, E., Komerički, A., Lukić, M., Pavlek, M., 2009. Crvena knjiga špiljske faune Hrvatske. Ministarstvo kulture Republike Hrvatske, Državni zavod za zaštitu prirode, Zagreb.

Pekár, S., Černecká, L'., Wolff, J., Mammola, S., Cardoso, P., Lowe, E., Fukushima, C.S., Birkhofer, K., Herberstein, M.E., 2021. The world arachnid trait database. Masaryk University, Brno. https://spidertraits.sci.muni.cz

Picardie Nature, 2016. Listes rouges régionales de la faune menacée de Picardie. les Chiroptères, les Mammifères terrestres, les Mammifères marins, les Amphibiens/Reptiles, les Araignées "orbitèles", les Coccinelles, les Orthoptères, les Odonates, les Rhopalocères et Zygènes.

Pineda, S.S, Chaumeil, P., Kunert, A., Kaas, Q., Thang, M.W.C, Le, L., Nuhn, M., Herzig, V., Saez, N.J., Cristofori-Armstrong, B., Anangi, R., Senff, S., Gorse, D., King, G.F., 2018. ArachnoServer 3.0: an online resource for automated discovery, analysis and annotation of spider toxins. Bioinformatics 34(6), 1074-1076. https://doi.org/10.1093/bioinformatics/btx661

Platen, R., Blick, T. Sacher, P., Malten, A., 1996. Rote Liste der Webspinnen Deutschlands (Arachnida: Araneae). Arachnol. Mitt. 11, 5-31.

Platen, R., Blick, T. Sacher, P., Malten, A., 1998. Rote Liste der Webspinnen (Arachnida: Araneae) (Bearbeitungsstand: 1996, 2. Fassung). In: Bundesamt für Naturschutz (Hrsg.). Rote Liste gefährdeter Tiere Deutschlands. Schriftenreihe für Landschaftspflege und Naturschutz 55, 268-275.

Platen, R., von Broen, B., 2002. Checkliste und Rote Liste der Webspinnen und Weberknechte (Arachnida: Araneae, Opiliones) des Landes Berlin mit Angaben zur Ökologie. Märkische Entomologische Nachrichten, Sonderheft 2, 1-69.

Platen, R., von Broen, B., Herrmann, A., Ratschker, U.M., Sacher, P., 1999. Gesamtartenliste und Rote Liste der Webspinnen, Weberknechte und Pseudoskorpione des Landes Brandenburg (Araneae, Opiliones, Pseudoscorpiones) mit Angaben zur Häufigkeit und Ökologie. Naturschutz und Landschaftspflege in Brandenburg 8(2), 1-79. 
Plesník, J., 1995. Návrh nových kritérií IUCN - Světového svazu ochrany přírody na zařazování druhú do červených seznamů. [The proposal of new criteria of the IUCN for classifying species in Red lists]. Ochrana př́rody 50, 19-23, 54-58, 86-90, 207.

Polenec, A., 1992. Rdeči seznam ogroženih pajkov (Aranea) Slovenije (The red list of endangered Aranea in Slovenia). Varstvo narave 17, 173-176.

Popov, I., Fadeeva, V., Palenova, E., Shamilishvily, G., Gorin, K., Burdo, A., Melchakova, E., Trofimova, Y., Sukristik, V., Morova, N., Kroo, K., Kirillova, Y., 2017. Effectiveness of "The IUCN red list of threatened species" application on a regional scale: current state of the "red books" of Russia. Bio. Comm. 62(1), 57-60. https://doi.org/10.21638/11701/ spbu03.2017.107

Rafalski, J., 1992. Pajęczaki - Arachnida. In: Głowaciński, Z. (Ed.), Czerwona lista zwierząt ginących i zagrożonych w Polsce. Zakład Ochr. Przyr. i Zasobów Nat. PAN, Kraków, pp. 103-104.

Rassi, P., Alanen, A., Kanerva, T., Mannerkoski, I., 2001. Suomen lajien uhanalaisuus 2000. Ympäristöministeriö \& Suomen ympäristökeskus, Helsinki.

Red Book of the Republic of Belarus, 2015. Krasnaia Kniga Respubliki Belarus': Zhivotnye: Redkie i Nakhodiashchiesia pod Ugrozoi Ischeznoveniia Vidy Dikikh Zhivotnykh [The Red Book of the Republic of Belarus: Animals: Rare and Endangered Species of Wild Animals] $4^{\text {th }}$ Edition, Minsk, Belarus.

Řezáč, M., Heneberg, P., 2014. Conservation status of the only representative of infraorder Mygalomorphae (Araneae) in cultivated regions of Central Europe. J. Insect Conserv. 18, 523-537. http://dx.doi.org/10.1007/s10841-014-9668-y.

Řezáč, M., Heneberg, P., 2019. Grazing as a conservation management approach leads to a reduction in spider species richness and abundance in acidophilous steppic grasslands on andesite bedrock. J. Insect Conserv. 23(4), 777-783. http://dx.doi.org/10.1007/s10841019-00163-9.

Řezáč, M., Kůrka, A., Růžička, V., Heneberg, P., 2015. Red List of Czech spiders: $3^{\text {rd }}$ edition, adjusted according to evidence-based national conservation priorities. Biologia 70(5), 645666. http://dx.doi.org/10.1515/biolog-2015-0079.

$4 y$

\section{Accepted manuscript}


Řezáč, M., Pekár, S., Johannesen, J., 2008. Taxonomic review and phylogenetic analysis of central European Eresus species (Araneae: Eresidae). Zool. Scr. 37(3), 263-287. http://dx.doi.org/10.1111/j.1463-6409.2008.00328.x

Řezáč, M., Řezáčová, V., Pekár, S., 2007. The distribution of purse-web Atypus spiders (Araneae: Mygalomorphae) in central Europe is constrained by microclimatic continentality and soil compactness. J. Biogeogr. 34, 1016-1027. https://doi.org/10.1111/j.13652699.2006.01670.x

Řezáč, M., Tošner, J., Heneberg, P., 2018. Habitat selection by threatened burrowing spiders (Araneae: Atypidae, Eresidae) of central Europe: evidence base for conservation management. J. Insect Conserv. 22, 135-149. https://doi.org/10.1007/s10841-018-0048-X.

Riciluca, K.C.T., Sayegh, R.S.R., Melo, R.L., Silva, P.I., 2012. Rondonin an antifungal peptide from spider (Acanthoscurria rondoniae) haemolymph. Results in Immunology 2, 6671. https://doi.org/10.1016/j.rinim.2012.03.001.

Rodrigues, A.S., Pilgrim, J.D., Lamoreux, J.F., Hoffmann, M., Brooks, T.M., 2006. The value of the IUCN Red List for conservation. Trends Ecol. Evol. 21(2), 71-76. https://doi.org/10.1016/j.tree.2005.10.010.

Ruffo, S., Stoch F. (Eds.), 2006. Checklist and distribution of the Italian fauna. 10,000 terrestrial and inland water species. Memorie del Museo Civico di Storia Naturale di Verona, 2. serie, Sezione Scienze della Vita, 17: 1-304.

Růžička, V., 2005. Araneae (pavouci). In: Farkač, J., Král, D., Škorpík, M. (Eds.), Červený seznam ohrožených druhů České republiky, Bezobratlí [Red list of threatened species in the Czech Republic, Invertebrates], Agentura ochrany př́rody a krajiny, Praha, pp. 76-82.

Sacher, P., Platen, R., 2001. Gesamtartenliste und Rote Liste der Webspinnen (Arachnida: Araneae) des Landes Sachsen-Anhalt mit Angaben zur Häufigkeit und Ökologie. Abhandlungen und Berichte für Naturkunde 24, 69-149.

Sacher, P., Platen, R., 2004. Rote Liste der Webspinnen (Arachnida: Araneae) des Landes Sachsen-Anhalt (2. Fassung, Stand Februar 2004). In: Landesamt für Umweltschutz Sachsen-Anhalt (Hrsg.), Rote Listen Sachsen-Anhalt. Halle (Saale) (Landesamt für Umweltschutz). Berichte des Landesamtes für Umweltschutz Sachsen-Anhalt 39, 190-197.

\section{Accepted manuscript}


Samways, M.J., Barton, P.S., Birkhofer, K., Chichorro, F., Deacon, C., Fartmann, T., Fukushima, C.S., Gaigher, R., Habel, J.C., Hallmann, C.A., Hill, M.J., Hochkirch, A., Kaila, L., Kwak, M.L., Maes, D., Mammola, S., Noriega, J.A., Orfinger, A., Pedraza, F., Pryke, J.S., Roque, F.O., Settele, J., Simaika, J.P., Stork, N.E., Suhling, F., Vorster, C., Cardoso, P., 2020. Solutions for humanity on how to conserve insects. Biol. Conserv. 242. https://doi.org/10.1016/j.biocon.2020.108427

Sander, F.W., Malt, S., Sacher, P., 2001. Rote Liste der Webspinnen (Araneae) Thüringens. 2. Fassung. Stand: 09/2001. Naturschutzreport 18, 55-63.

Schembri, P.J., Sultana, J. (Eds.), 1989. Red data book for the Maltese islands. Department of Inform, Environment division of Ministry of Education.

Schnittler, M., Ludwig, G., Pretscher, P., Boye, P., 1994. Konzeption der Roten Listen der in Deutschland gefährdeten Tier- und Pflanzenarten unter Berücksichtigung der neuen internationalen Kategorien. Natur und Landschaft 69(10), 451-459.

Seibold, S., Gossner, M.M., Simons, N.K., Blüthgen, N., Müller, J., Ambarlı, D., Ammer, C., Bauhus, J., Fischer, M., Habel, J.C., Linsenmair, K.E., Nauss, T., Penone, C., Prati, D., Schall, P., Schulze, E.-D., Vogt, J., Wöllauer, S., Weisser, W.W., 2019. Arthropod decline in grasslands and forests is associated with landscape-level drivers. Nature 574(7780), 671674. https://doi.org/10.1038/s41586-019-1684-3.

Seppälä, S., Henriques, S., Draney, M.L., Foord, S., Gibbons, A.T., Gomez, L.A., Kariko, S., Malumbres-Olarte, J., Milne, M., Vink, C.J., Cardoso, P., 2018a. Species conservation profiles of a random sample of world spiders I: Agelenidae to Filistatidae. Biodivers. Data J. 6, e23555. https://doi.org/10.3897/BDJ.6.e23555.

Seppälä, S., Henriques, S., Draney, M.L., Foord, S., Gibbons, A.T., Gomez, L.A., Kariko, S., Malumbres-Olarte, J., Milne, M., Vink, C.J., Cardoso, P., 2018b. Species conservation profiles of a random sample of world spiders II: Gnaphosidae to Nemesiidae. Biodivers. Data J. 6, e26203. https://doi.org/10.3897/BDJ.6.e26203.

Seppälä, S., Henriques, S., Draney, M.L., Foord, S., Gibbons, A.T., Gomez, L.A., Kariko, S., Malumbres-Olarte, J., Milne, M., Vink, C.J., Cardoso, P., 2018c. Species conservation

\section{Accepted manuscript}


profiles of a random sample of world spiders III: Oecobiidae to Salticidae. Biodivers. Data J. 6, e27004. https://doi.org/10.3897/BDJ.6.e27004.

Seppälä, S., Henriques, S., Draney, M.L., Foord, S., Gibbons, A.T., Gomez, L.A., Kariko, S., Malumbres-Olarte, J., Milne, M., Vink, C.J., Cardoso, P., 2018d. Species conservation profiles of a random sample of world spiders IV: Scytodidae to Zoropsidae. Biodivers. Data J. 6, e27004. https://doi.org/10.3897/BDJ.6.e30842.

Seymour, R.S., Hetz, S.K., 2011. The diving bell and the spider: the physical gill of Argyroneta aquatica. J. Exp. Biol. 214, 2175-2181. https://doi.org/10.1242/jeb.056093.

Shirey, V., Seppälä, S., Branco, V.V., Cardoso, P., 2019. Current GBIF occurrence data demonstrates both promise and limitations for potential red listing of spiders. Biodivers. Data J. 7, e47369. https://doi.org/10.3897/BDJ.7.e47369.

SLU Artdatabanken, 2020. Rödlistade arter i Sverige 2020. SLU, Uppsala.

Smith, H., 2000. The status and conservation of the fen raft spider (Dolomedes plantarius) at Redgrave and Lopham Fen National Nature Reserve, England. Biol. Conserv. 95, 153164. https://doi.org/10.1016/S0006-3207(00)00030-6.

Smith, H., Clarke, D., Heaver, D., Hughes, I., Pearce-Kelly, P., Sainsbury, T., 2013. Translocation and augmentation of the fen raft spider populations in the UK. In: Soorae, P.S. (Ed.) Global re-introduction perspectives: 2013: further case studies from around the globe. IUCN, Gland, Switzerland.

Snazell, R., 1986. The spider genus Macrothele Ausserer in Spain (Araneae; Dipluridae). Bull. Br. Ecol. Soc. 17(2), 80-83.

Snazell, R., Allison, R., 1989. The genus Macrothele Ausserer (Araneae, Hexathelidae) in Europe. Bull. Br. Arachnol. Soc. 8(3), 65-72.

Eurobarometer, 2008. Attitudes of European citizens towards the environment. Special Eurobarometer Report 295/ Wave 68.2. European Commission, Brussels.

Spuris, Z., Barševskis, A., Cinītis, M., Ozoloṇš, K., Parele, E., Pilāte, D., Piterāns, A., Poikāns, M., Rudzīte, M., Savenkovs, N., Spuṇǵis, V., Šternbergs, M., 1998. Latvijas Sarkanā grāmata. Bezmugurkaulnieki, 4.sēj. [Red Data Book of Latvia. Rare and 52

\section{Accepted manuscript}


endangered species of animals and plants. Volume 4. Invertebrates]. Institute of Biology, Riga.

Staręga, W., Błaszak, C., Rafalski, J., 2002. Arachnida. Pajęczaki. Czerwona lista gatunków [Arachnida, Spiders. Red list]. In: Głowaciński, Z. (Ed.), Czerwona lista zwierząt ginących i zagrożonych w Polsce, Suplement [Red list of threatened animals in Poland, Supplement]. Instytut Ochrony Przyrody PAN, Kraków, pp. 133-140.

Staręga, W., Majkus, Z., Miszta, A., 2001. Czerwona lista pająków (Araneae) Górnego Śląska [Red List of Upper Silesian spiders (Araneae)]. Raporty Opinie 5, 8-36.

Stork, N.E., 2018. How many species of insects and other terrestrial arthropods are there on Earth? Annu. Rev. Entomol. 63, 31-45. https://www.annualreviews.org/doi/10.1146/annurev-ento-020117-043348

Sukopp, H., 1974. "Rote Liste" der in der Bundesrepublik Deutschland gefährdeten Arten von Farn- und Blütenpflanzen (1. Fassung). Natur und Landschaft 49(12), 315-322.

Titley, M.A., Snaddon, J.L., Turner, E.C., 2017. Scientific research on animal biodiversity is systematically biased towards vertebrates and temperate regions. PLoS One 12(12), e0189577. https://doi.org/10.1371/journal.pone.0189577.

Tokarsky, V. (Ed.), 2013. Chervona Knyha Kharkivskoi Oblasti. Tvarynnyi Svit [Red Data Book of Kharkiv Region of Ukraine. Animals]. V.N. Karazin Kharkiv National University, Kharkiv.

Trouwborst, A., Blackmore, A., Boitani, L., Bowman, M., Caddell, R., Chapron, G., Cliquet, A., Couzens, E., Epstein, Y., Fernández-Galiano, E., Fleurke, F.M., Gardner, R., Hunter, L., Jacobsen, K., Krofel, M., Lewis, M., López-Bao, J.V., Macdonald, D., Redpath, S., Wandesforde-Smith, G., Linnell, J.D.C., 2017. International wildlife law: understanding and enhancing its role in conservation. BioScience 67(9), 784-790. https://doi.org/10.1093/biosci/bix086.

Turnbull, A.L., 1973. Ecology of the true spiders (Araneomorphae). Annu. Rev. Entomol. 18, 305-348. https://doi.org/10.1146/annurev.en.18.010173.001513. 
Uradni list Republike Slovenije, 2002. Pravilnik o uvrstitvi ogroženih rastlinskih in živalskih vrst $v$ rdeči seznam MP82/02: 8893-8975. Version 2002. http://www.uradnilist.si/1/ulonline.jsp?urlid=200282\&dhid=44228.

van Helsdingen, P.J., 1993. Can Macrothele calpeiana (Walckenaer) (Araneae, Hexathelidae) be used as a bio-indicator? Bull. Soc. Neuchâtel. Sci. Nat. 116, 253-258.

van Helsdingen, P., Decae, A., 1992. Ecology, distribution and vulnerability of Macrothele calpeiana (Walckenaer)(Araneae, Hexathelidae). Tijdschr. Entomol. 135, 169-178.

van Swaay, C., Collins, C., Dušej, G., Maes, D., Munguira, M.L., Rakosy, L., Ryrholm, N., Šašić, M., Settele, J., Thomas, J.A., Verovnik, R., Verstrael, T., Warren, M., Wiemers, M., Wynhoff, I., 2012. Dos and Don'ts for butterflies of the Habitats Directive of the European Union. Nature Conservation 1, 73-153. https://doi.org/10.3897/natureconservation.1.2786.

van Swaay, C., Cuttelod, A., Collins, S., Maes, D., López Munguira, M., Šašić, M., Settele, J., Verovnik, R., Verstrael, T., Warren, M., Wiemers, M., Wynhof, I., 2010. European Red List of Butterflies Luxembourg: Publications Office of the European Union.

Vangsgård, C., Reinke, H.-D., Schultz, W., van Helsdingen, P.J., 1996. Red List of spiders (Araneae) of the Wadden Sea Area. Helgoländer Meeresunters. 50(1), 77-82. https://doi.org/10.1007/BF02366175.

Verdú, J.R., Numa, C., Galante, E., 2011. Atlas y Libro Rojo de los Invertebrados amenazados de España (Especies Vulnerables). Dirección General de Medio Natural y Política Forestal, Ministerio de Medio Ambiente, Medio rural y Marino, Madrid.

Von Nordheim, H., Andersen, O. N., Thissen, J., Merck, T., 1997. Red Lists of biotopes, flora and fauna of the trilateral Wadden Sea area, 1995. Oceanograph. Lit. Rev. 11(44), 1297-1298.

Wang, Y., Casajus, N., Buddle, C., Berteaux, D., Larrivée, M. 2018. Predicting the distribution of poorly-documented species, Northern black widow (Latrodectus variolus) and Black purse-web spider (Sphodros niger), using museum specimens and citizen science data. PLoS ONE 13, e0201094. 
Wells, S.M., Pyle, R.M., Collins, N.M., 1983. The IUCN Invertebrate Red Data Book. IUCN, Gland, Switzerland.

Wilson, E.O., 1987. The little things that run the world (the importance and conservation of invertebrates). Conserv. Biol. 1(4): 344-346 https://doi.org/10.1111/j.15231739.1987.tb00055.x

Witkowski, Z.J., Król, W., Solarz, W. (Eds.), 2003. Carpathian List of Endangered Species. WWF and Institute of Nature Conservation, Polish Academy of Sciences, Vienna-Krakow.

World Conservation Monitoring Centre, 1996a. Dolomedes plantarius. The IUCN Red List of Threatened Species 1996: e.T6790A12806270 (downloaded 27 November 2019).

World Conservation Monitoring Centre, 1996b. Macrothele cretica. The IUCN Red List of Threatened Species 1996: e.T12649A3368483 (downloaded 27 November 2019). http://dx.doi.org/10.2305/IUCN.UK.1996.RLTS.T12649A3368483.en.

World Conservation Monitoring Centre, 1996c. Troglohyphantes gracilis. The IUCN Red List of Threatened Species 1996: e.T22274A9369284 (downloaded 27 November 2019). https://dx.doi.org/10.2305/IUCN.UK.1996.RLTS.T22274A9369284.en.

World Conservation Monitoring Centre, 1996d. Troglohyphantes similis. The IUCN Red List of Threatened Species 1996: e.T22275A9369404 (downloaded 27 November 2019). https://dx.doi.org/10.2305/IUCN.UK.1996.RLTS.T22275A9369404.en.

World Conservation Monitoring Centre, 1996e. Troglohyphantes spinipes. The IUCN Red List of Threatened Species 1996: e.T22276A9369524 (downloaded 27 November 2019). https://dx.doi.org/10.2305/IUCN.UK.1996.RLTS.T22276A9369524.en.

World Spider Catalog, 2020. World Spider Catalog. Version 21.0. Natural History Museum Bern. http://wsc.nmbe.ch (accessed 11 March 2020). doi: 10.24436/2

Zalevskiy V., Bronskov A. (Eds.), 2017. Chervona Knyha Donetskoi Oblasti: Tvarynnyi Svit. Naukovo-Informatsiinyi Dovidnyk [Red Data Book of Donetsk Region: Animals. Scientific information guide]. PJSC Vinnytsia Printing House, Vinnytsia. 


\section{FIGURES}

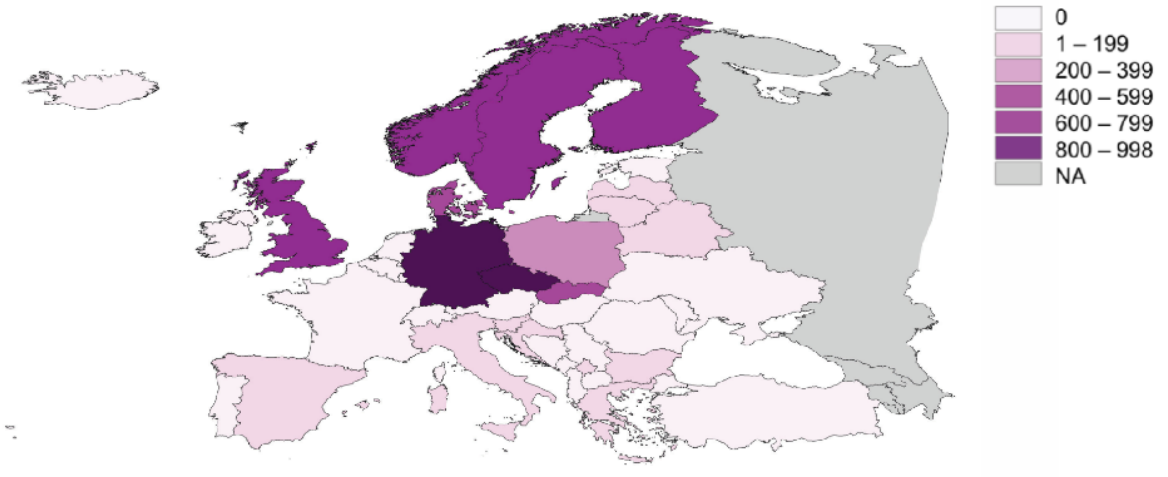

(a)

Number of species in national Red Lists

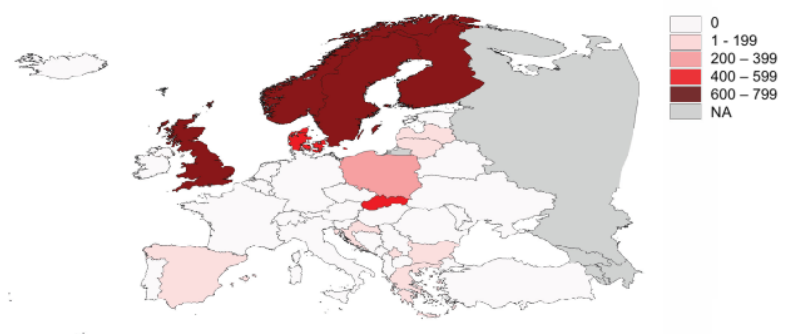

(b) Number of species in national IUCN Red List

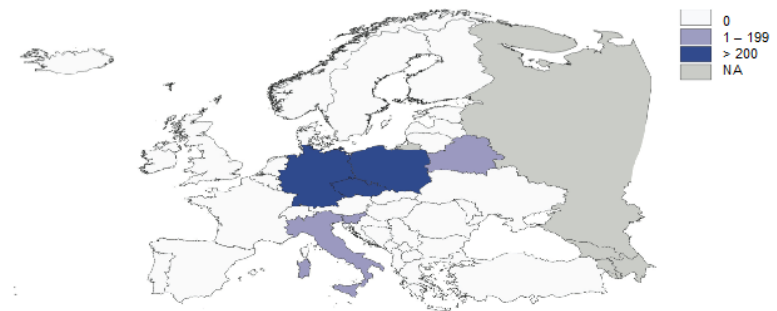

(c) Number of species in national non-IUCN Red Lists

Figure 1. - Number of spider species considered by inventories of threatened species in Europe. (a) Number of species listed in national Red Lists in Europe (Malta, not displayed in map, is in the range 1-199; (b) Number of species listed in national IUCN Red Lists in Europe; (c) Number of species listed in national non-IUCN Red Lists in Europe (Malta, not displayed in map, is in the range 1-199). Northern and Central European countries stand for having the highest number of species mentioned in Red Lists. NA = Not Available. 


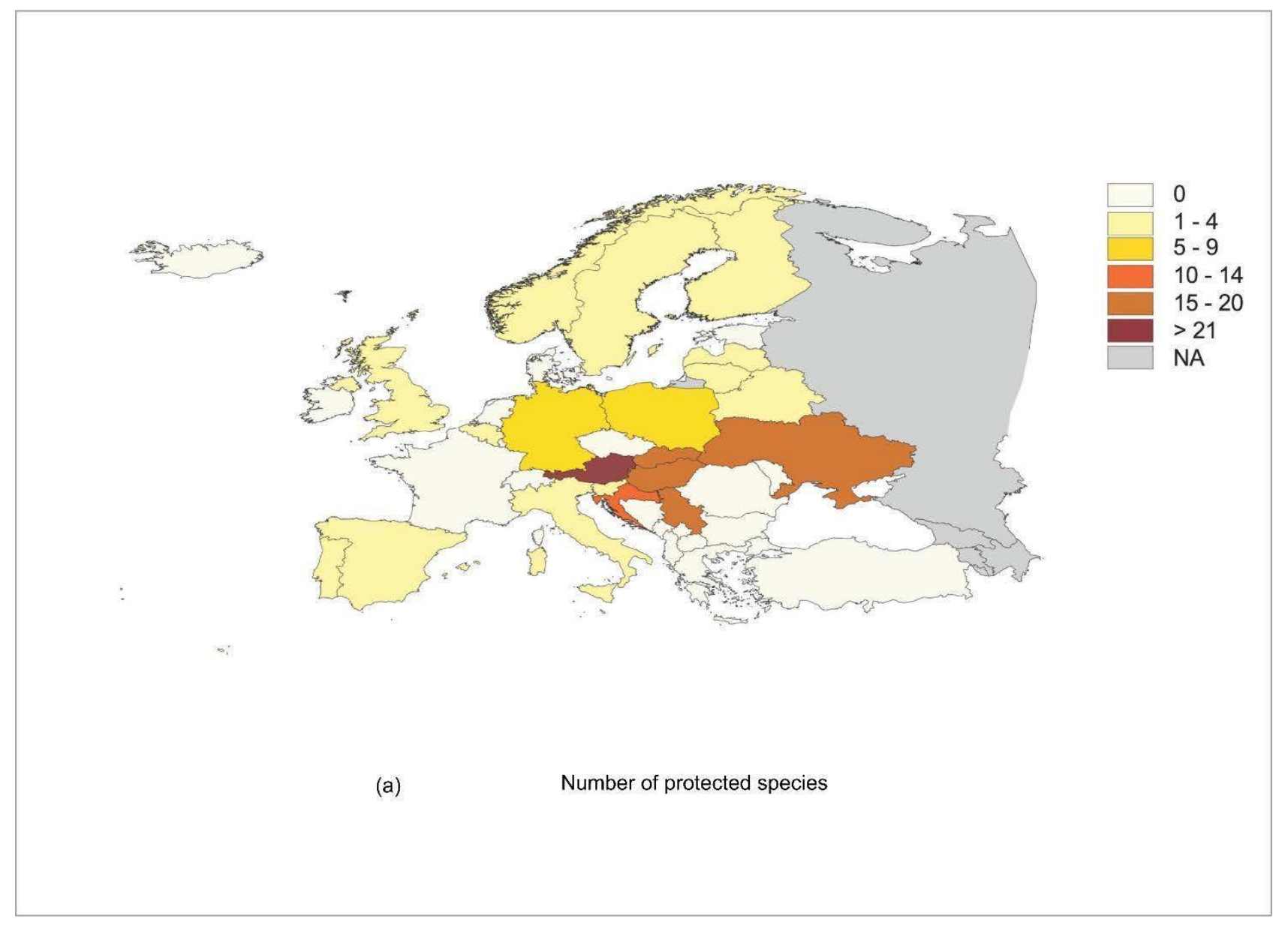

Figure 2. - Number of spider species protected by legislation in European countries (a). Central-Eastern European countries have the highest number of protected species. Note that an additional 38 species are listed as species of "principal importance" for conservation, receiving a lower level of protection under UK laws (see text). NA = Not Available. 


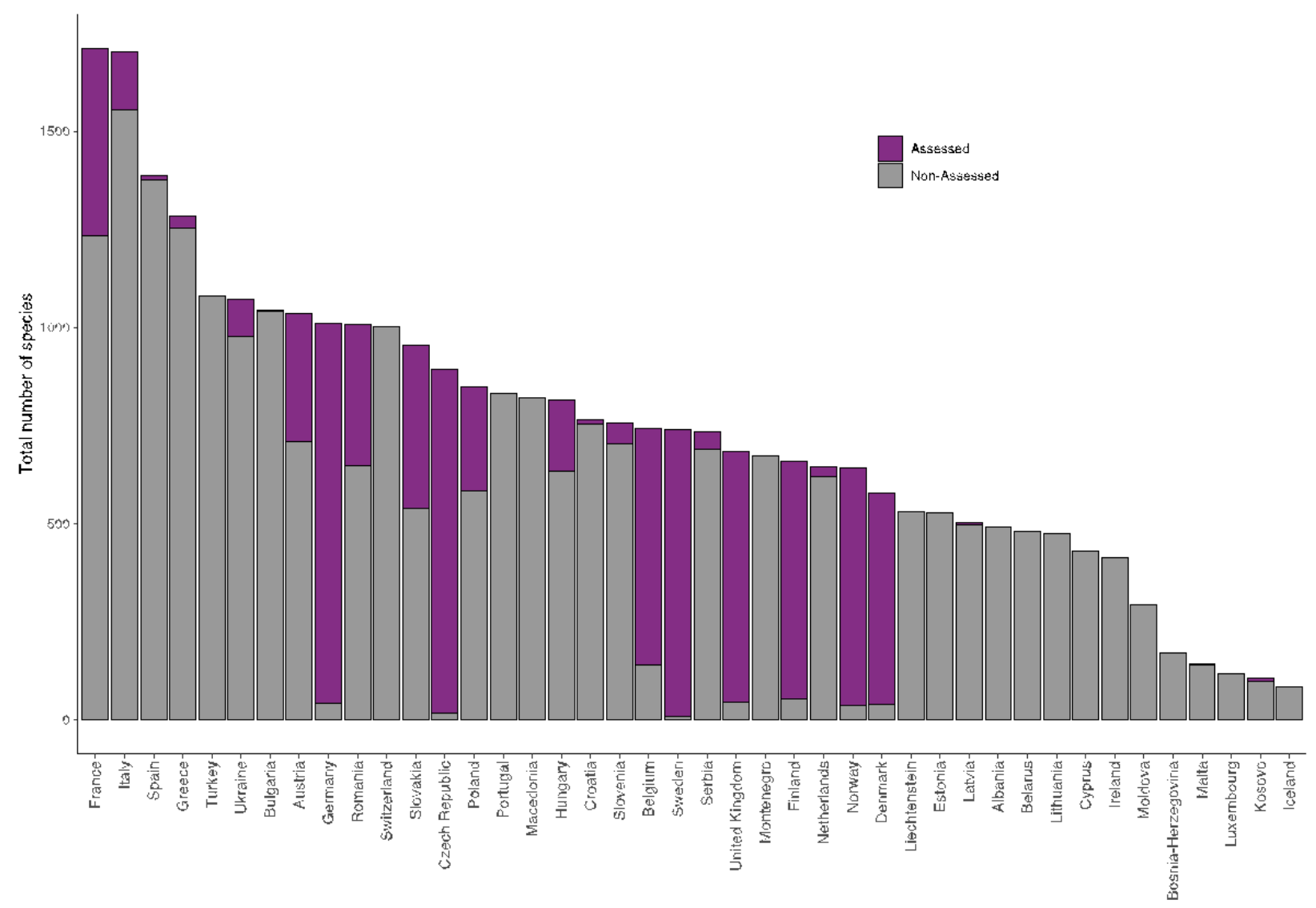

Figure 3. - Number of spider species assessed in Red Lists and Red Data Books in Europe in relation to the total number of spider species per country as reported in Nentwig et al. (2020). There is no correlation between the number of species occurring in a country and the number of species assessed in Red Lists and Red Data Books. 


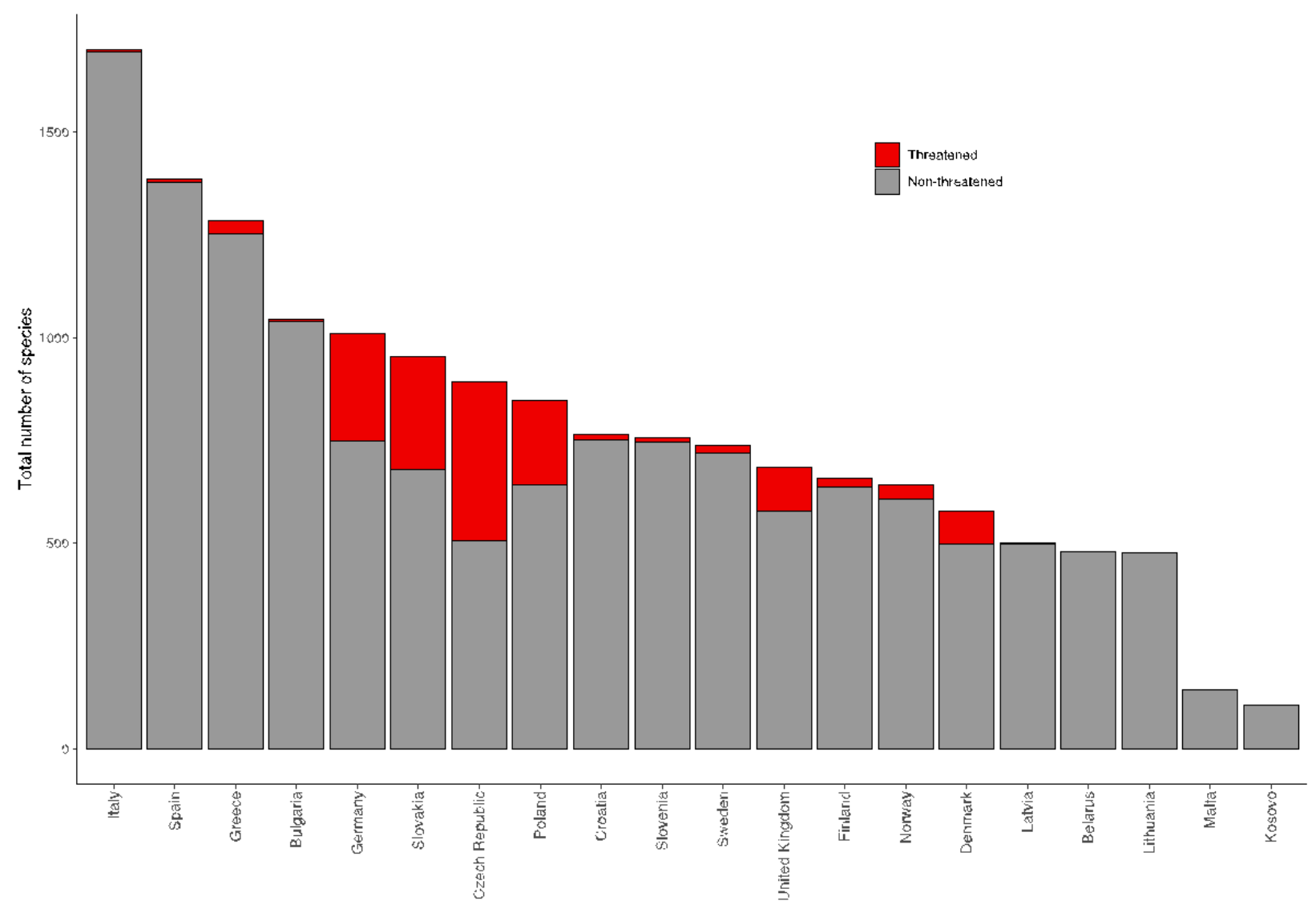

Figure 4. - Number of spider species considered as threatened in national Red Lists and Red Data Books in relation to the total number of spider species per country as reported in Nentwig et al. (2020). There is no correlation between the number of species occurring in a country and the number of threatened species in Red Lists and Red Data Books 


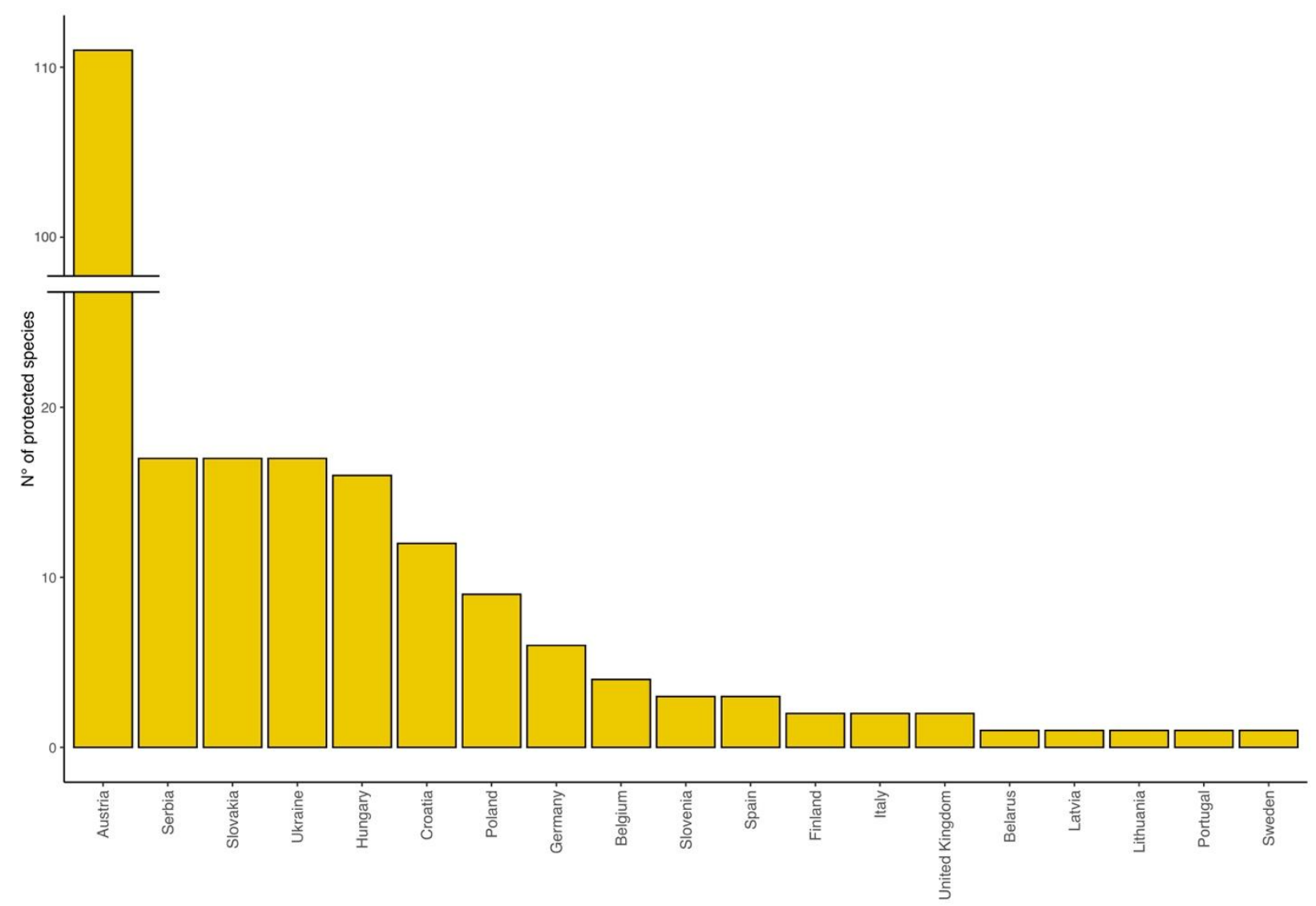

Figure 5. - Number of legally protected spider species in European countries. Note that an additional 38 species are listed as species of "principal importance" for conservation, receiving a lower level of protection under UK laws (see text). 

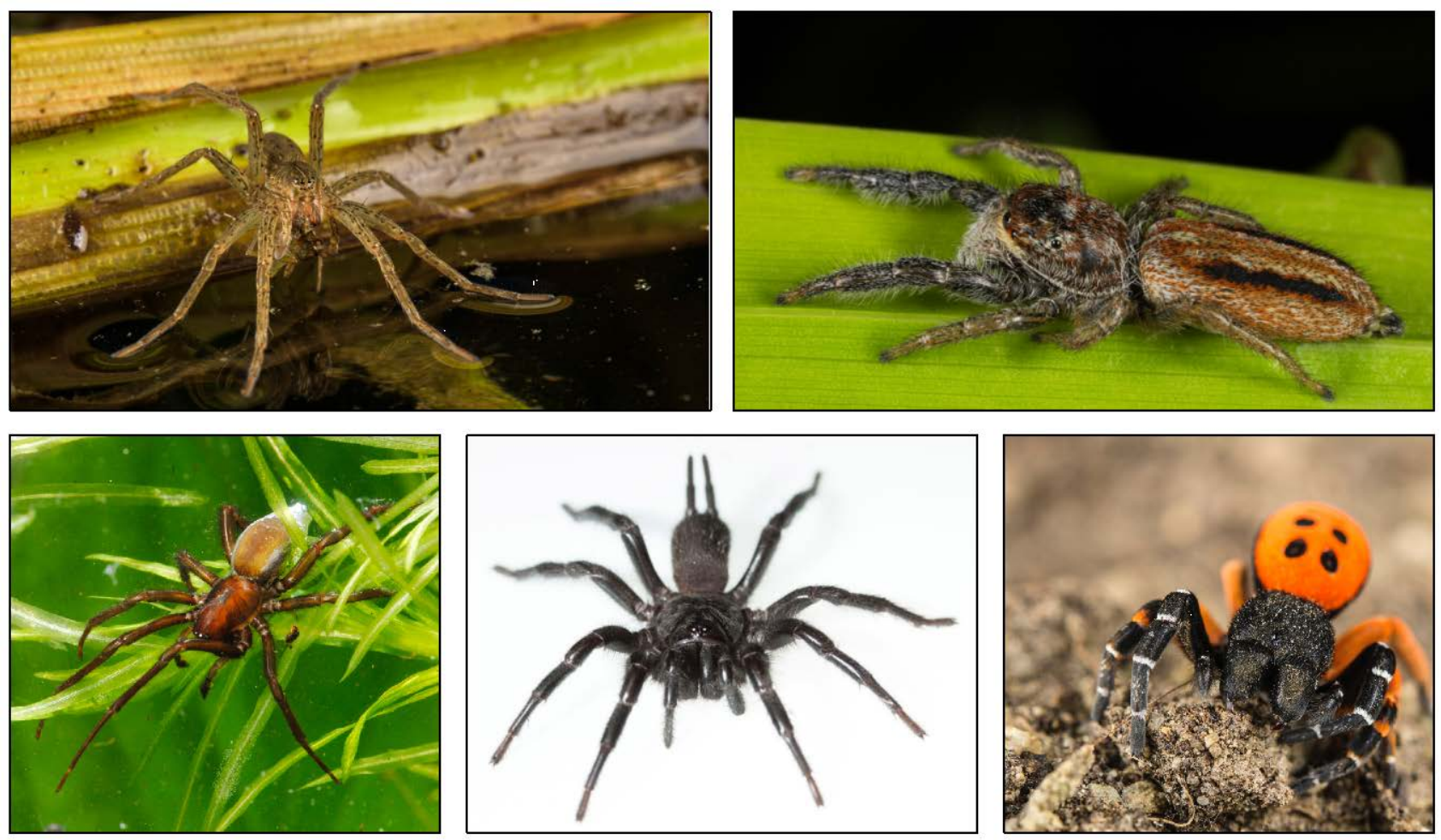

Figure 6. - Highlights in spider conservation in Europe. Dolomedes plantarius (above left, Photo credit Emanuele Biggi), Marpissa radiata (above right, Photo credit Janusz Kupryjanowicz), Argyroneta aquatica (below left, Photo credit Emanuele Biggi) and Eresus spp. (below right, Photo credit Emanuele Biggi) benefit from full legal protection in several countries across Europe and have been assessed as threatened in most European countries. Macrothele calpeiana (below center, Photo credit Tiziano D'Elia) is the only native European spider species that features in the Habitats Directive and the Bern Convention. 


\section{TABLES}

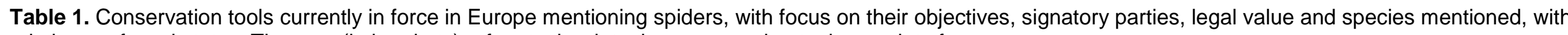
relative conferred status. The year (in brackets) refers to the date the conservation tool came into force.

\begin{tabular}{|c|c|c|c|c|c|c|c|c|}
\hline Level & Conservation tool & Objectives & $\begin{array}{l}\text { Signatory } \\
\text { parties }\end{array}$ & $\begin{array}{l}\text { Legal } \\
\text { value }\end{array}$ & $\begin{array}{c}\text { Spider } \\
\text { species } \\
\text { mentioned }\end{array}$ & $\begin{array}{l}\text { European } \\
\text { species } \\
\text { included }\end{array}$ & $\begin{array}{l}\text { Conferred } \\
\text { status }\end{array}$ & Notes \\
\hline \multirow{2}{*}{$\begin{array}{c}\text { Interna } \\
\text { tional }\end{array}$} & $\begin{array}{l}\text { Bern Convention } \\
\qquad(1982)\end{array}$ & $\begin{array}{l}\text { to conserve } \\
\text { wild flora and fauna a } \\
\text { nd their natural } \\
\text { habitats } \\
\text { to promote } \\
\text { cooperation between } \\
\text { States } \\
\text { to give particular } \\
\text { attention to } \\
\text { endangered } \\
\text { and vulnerable } \\
\text { species including } \\
\text { endangered and } \\
\text { vulnerable migratory } \\
\text { species }\end{array}$ & $\begin{array}{l}51 \\
\text { EU countries, } \\
\text { other } \\
\text { European } \\
\text { countries, } \\
\text { some African } \\
\text { and Middle } \\
\text { Eastern } \\
\text { countries }\end{array}$ & No & 1 & 1 & $\begin{array}{c}\text { Strictly } \\
\text { protected }\end{array}$ & $\begin{array}{l}\text { - opened for signature in } 1979 \\
\text { by European environment } \\
\text { ministers, and came into force } \\
\text { in } 1982 \text { with the approval of the } \\
\text { Council of the European Union } \\
\text { the first international act } \\
\text { addressing the conservation of } \\
\text { wild species in Europe } \\
\text { a voluntary agreement, } \\
\text { constituting no law or } \\
\text { obligation, aiming to protect } \\
\text { wild flora, fauna, and their } \\
\text { natural habitats (listed in the } \\
\text { appendices). }\end{array}$ \\
\hline & $\begin{array}{c}\text { CITES } \\
\text { (1975 worldwide, } 1996 \text { in } \\
\text { EU) }\end{array}$ & $\begin{array}{l}\text { to ensure that } \\
\text { international trade in } \\
\text { specimens of wild } \\
\text { animals and plants } \\
\text { does not threaten } \\
\text { their survival }\end{array}$ & $\begin{array}{l}183 \\
\text { countries from } \\
\text { all continents }\end{array}$ & Yes & 36 & 0 & $\begin{array}{l}\text { Species } \\
\text { not } \\
\text { necessarily } \\
\text { threatened } \\
\text { with } \\
\text { extinction } \\
\text { but that } \\
\text { may } \\
\text { become so } \\
\text { unless } \\
\text { trade is } \\
\text { closely } \\
\text { controlled }\end{array}$ & $\begin{array}{l}\text { - the conservation agreement } \\
\text { with the largest membership } \\
\text { an international agreement } \\
\text { between governments aiming } \\
\text { to regulate and monitor the } \\
\text { international trade in wild } \\
\text { species } \\
\text { drafted as a result of a } \\
\text { resolution adopted in } 1963 \text { at a } \\
\text { IUCN meeting } \\
\text { although legally binding on the } \\
\text { Parties, CITES does not take } \\
\text { the place of national laws }\end{array}$ \\
\hline
\end{tabular}




\begin{tabular}{|c|c|c|c|c|c|c|c|c|}
\hline & & & & & & & $\begin{array}{l}\text { (Appendix } \\
\text { II) }\end{array}$ & $\begin{array}{l}\text { - none of the spiders listed occur } \\
\text { naturally in Europe }\end{array}$ \\
\hline & $\begin{array}{l}\text { Habitats Directive } \\
\qquad \begin{array}{c}\text { (92/43/EEC) } \\
(1992)\end{array}\end{array}$ & $\begin{array}{l}\text { to protect habitats } \\
\text { and species listed in } \\
\text { the directive's } \\
\text { Annexes }\end{array}$ & $\begin{array}{l}27 \\
\text { EU countries }\end{array}$ & Yes & 1 & 1 & $\begin{array}{l}\text { Strictly } \\
\text { protected }\end{array}$ & $\begin{array}{l}\text { - the EU response to the Bern } \\
\text { Convention } \\
\text { the main legal document } \\
\text { regulating Europe's nature } \\
\text { conservation policy, together } \\
\text { with the Birds Directive } \\
\text { (2009/147/EC), } \\
\text { a European law, mandatorily } \\
\text { transposed to national laws of } \\
\text { EU countries. }\end{array}$ \\
\hline & $\begin{array}{c}\text { IUCN Red List of } \\
\text { Threatened Species } \\
\text { (1964) }\end{array}$ & $\begin{array}{l}\text { to evaluate and } \\
\text { classify the global } \\
\text { conservation status } \\
\text { of the species, } \\
\text { classifying them in } \\
\text { categories of risk }\end{array}$ & $\begin{array}{l}\text { No signatory } \\
\text { parties, only } \\
\text { partner } \\
\text { Member } \\
\text { Organisations } \\
\text { (States, } \\
\text { government } \\
\text { agencies, } \\
\text { NGOs, } \\
\text { Scientific } \\
\text { Societies) }\end{array}$ & No & 293 & 8 & $\begin{array}{c}\text { Critically } \\
\text { Endangere } \\
\text { d (2 } \\
\text { species), } \\
\text { Endangere } \\
\text { d (1 } \\
\text { species), } \\
\text { Vulnerable } \\
\text { (4 species), } \\
\text { Data } \\
\text { Deficient (1 } \\
\text { species) }\end{array}$ & $\begin{array}{l}\text { - the first international } \\
\text { organization to focus on the } \\
\text { protection and sustainable use } \\
\text { of natural resources } \\
\text { one of the main authorities on } \\
\text { environmental management } \\
\text { and nature conservation } \\
\text { commonly used in decision- } \\
\text { making process and as a guide } \\
\text { to revise international or local } \\
\text { agreements such as CITES }\end{array}$ \\
\hline $\begin{array}{l}\text { Region } \\
\quad \text { al }\end{array}$ & $\begin{array}{l}\text { National IUCN Red Lists } \\
\text { and Red Data Books }\end{array}$ & $\begin{array}{l}\text { - } \text { to evaluate and } \\
\text { classify the } \\
\text { conservation status } \\
\text { of species at national } \\
\text { level, classifying } \\
\text { them in categories of } \\
\text { risk following the } \\
\text { IUCN standards }\end{array}$ & $\begin{array}{l}\text { No signatory } \\
\text { parties. } \\
13 \text { Countries } \\
\text { providing Red } \\
\text { Lists }\end{array}$ & No & 1098 & 1098 & $\begin{array}{l}\text { Species } \\
\text { listed in the } \\
\text { IUCN } \\
\text { categories }\end{array}$ & $\begin{array}{l}\text { - commonly used in decision- } \\
\text { making process }\end{array}$ \\
\hline
\end{tabular}




\begin{tabular}{|c|c|c|c|c|c|c|c|}
\hline $\begin{array}{c}\text { National non-IUCN Red } \\
\text { Lists and Red Data } \\
\text { Books }\end{array}$ & $\begin{array}{l}\text { - to evaluate and } \\
\text { classify } \\
\text { the conservation } \\
\text { status of species at } \\
\text { national level, } \\
\text { classifying them in } \\
\text { categories of risk } \\
\text { according to modified } \\
\text { IUCN criteria, } \\
\text { national guidelines or } \\
\text { expert opinions }\end{array}$ & $\begin{array}{l}\text { No signatory } \\
\text { parties. } \\
7 \text { Countries } \\
\text { providing Red } \\
\text { Lists }\end{array}$ & No & 1178 & 1178 & $\begin{array}{l}\text { Varying } \\
\text { categories } \\
\text { of } \\
\text { extinction } \\
\text { risk }\end{array}$ & $\begin{array}{l}\text { - commonly used in decision- } \\
\text { making process }\end{array}$ \\
\hline $\begin{array}{c}\text { Sub- or supranational } \\
\text { IUCN Red Lists and Red } \\
\text { Data Books }\end{array}$ & $\begin{array}{l}\text { to evaluate and } \\
\text { classify the } \\
\text { conservation status of } \\
\text { species at the } \\
\text { subnational level, } \\
\text { classifying them in } \\
\text { categories of } \\
\text { extinction risk } \\
\text { following the IUCN } \\
\text { standards } \\
\end{array}$ & $\begin{array}{l}\text { No signatory } \\
\text { parties. } \\
12 \text { regions } \\
\text { providing Red } \\
\text { Lists }\end{array}$ & No & 1041 & 1041 & $\begin{array}{l}\text { Species } \\
\text { listed in the } \\
\text { IUCN } \\
\text { categories }\end{array}$ & $\begin{array}{l}\text { - commonly used in decision- } \\
\text { making process }\end{array}$ \\
\hline $\begin{array}{l}\text { Sub- or supranational } \\
\text { non-IUCN Red Lists and } \\
\text { Red Data Books }\end{array}$ & $\begin{array}{l}\text { to evaluate and } \\
\text { classify the } \\
\text { conservation status } \\
\text { of species at the } \\
\text { subnational level, } \\
\text { classifying them in } \\
\text { categories of } \\
\text { extinction risk } \\
\text { according to modified } \\
\text { IUCN criteria, } \\
\text { national guidelines or } \\
\text { expert opinions } \\
\end{array}$ & $\begin{array}{l}\text { No signatory } \\
\text { parties. } \\
19 \text { regions } \\
\text { providing Red } \\
\text { Lists }\end{array}$ & No & 1099 & 1099 & $\begin{array}{l}\text { Varying } \\
\text { categories } \\
\text { of } \\
\text { extinction } \\
\text { risk }\end{array}$ & $\begin{array}{l}\text { - commonly used in decision- } \\
\text { making process }\end{array}$ \\
\hline National laws & $\begin{array}{l}\text { to protect the species } \\
\text { within the national } \\
\text { territory }\end{array}$ & 19 Countries & Yes & 178 & 178 & $\begin{array}{l}\text { Legally } \\
\text { protected } \\
\text { at the } \\
\text { national } \\
\text { level }\end{array}$ & $\begin{array}{l}\text { - The preeminent instruments to } \\
\text { protect species }\end{array}$ \\
\hline
\end{tabular}


Table 2. Regional Red Lists (RLs) and Red Data Books (RDBs) at national and subnational level in the European countries, showing the number of spider species known for each country, relative number of species assessed and number of species considered as extinct and/or threatened, compliance with IUCN standards, references to the species list, and number of native European spider species on the Global Red List. For detailed information on spider conservation in each European country, see Appendix B.

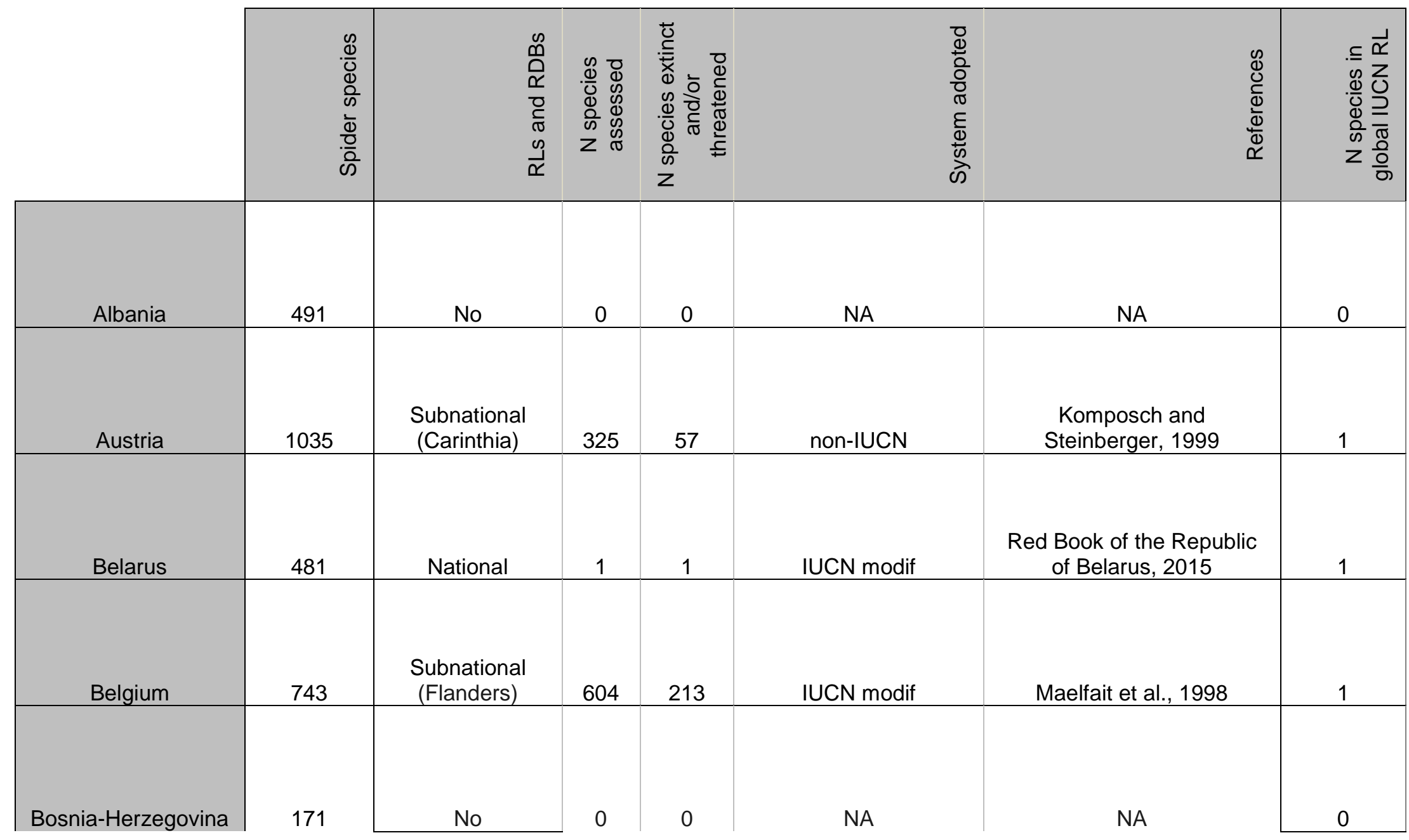




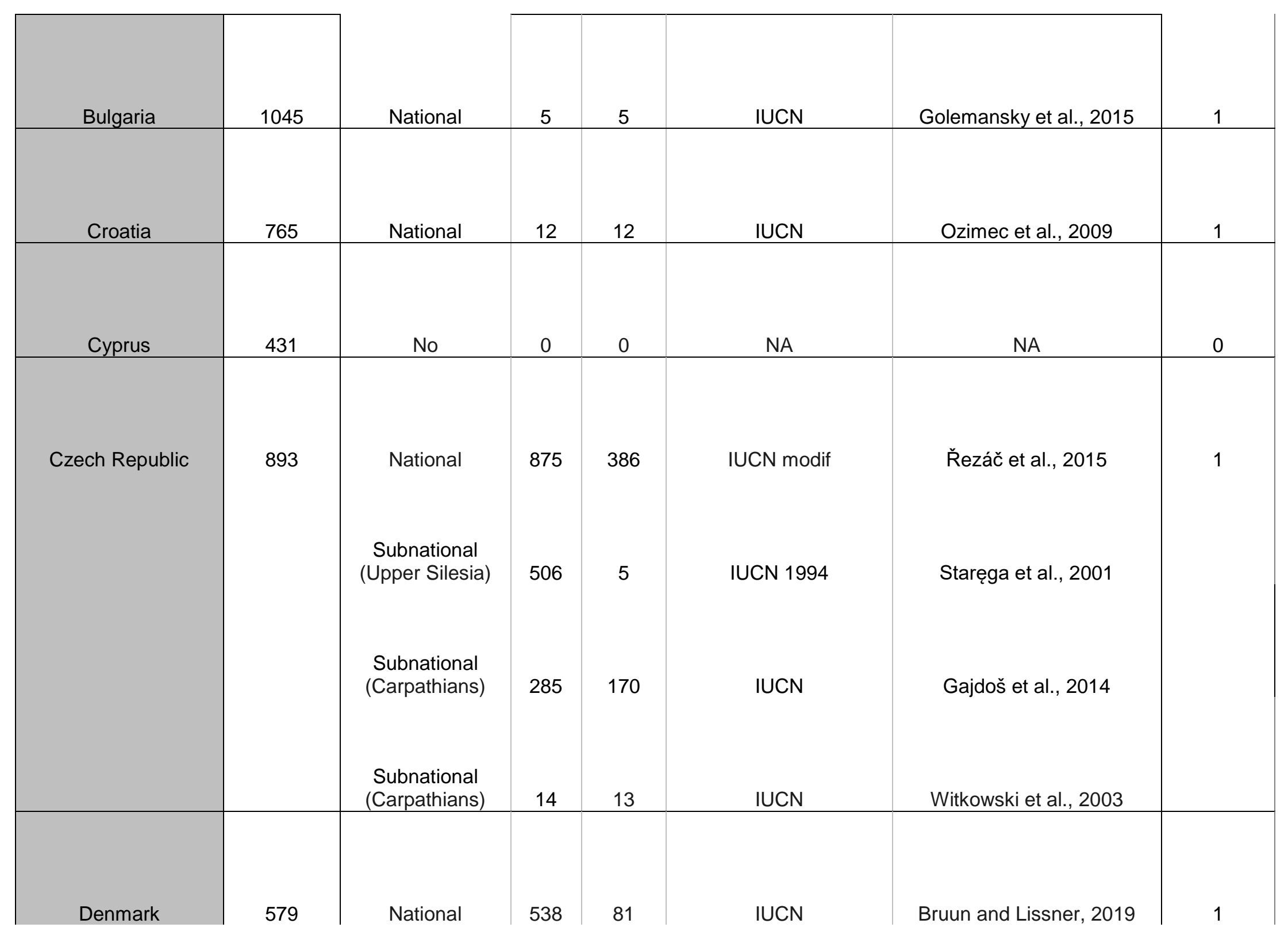




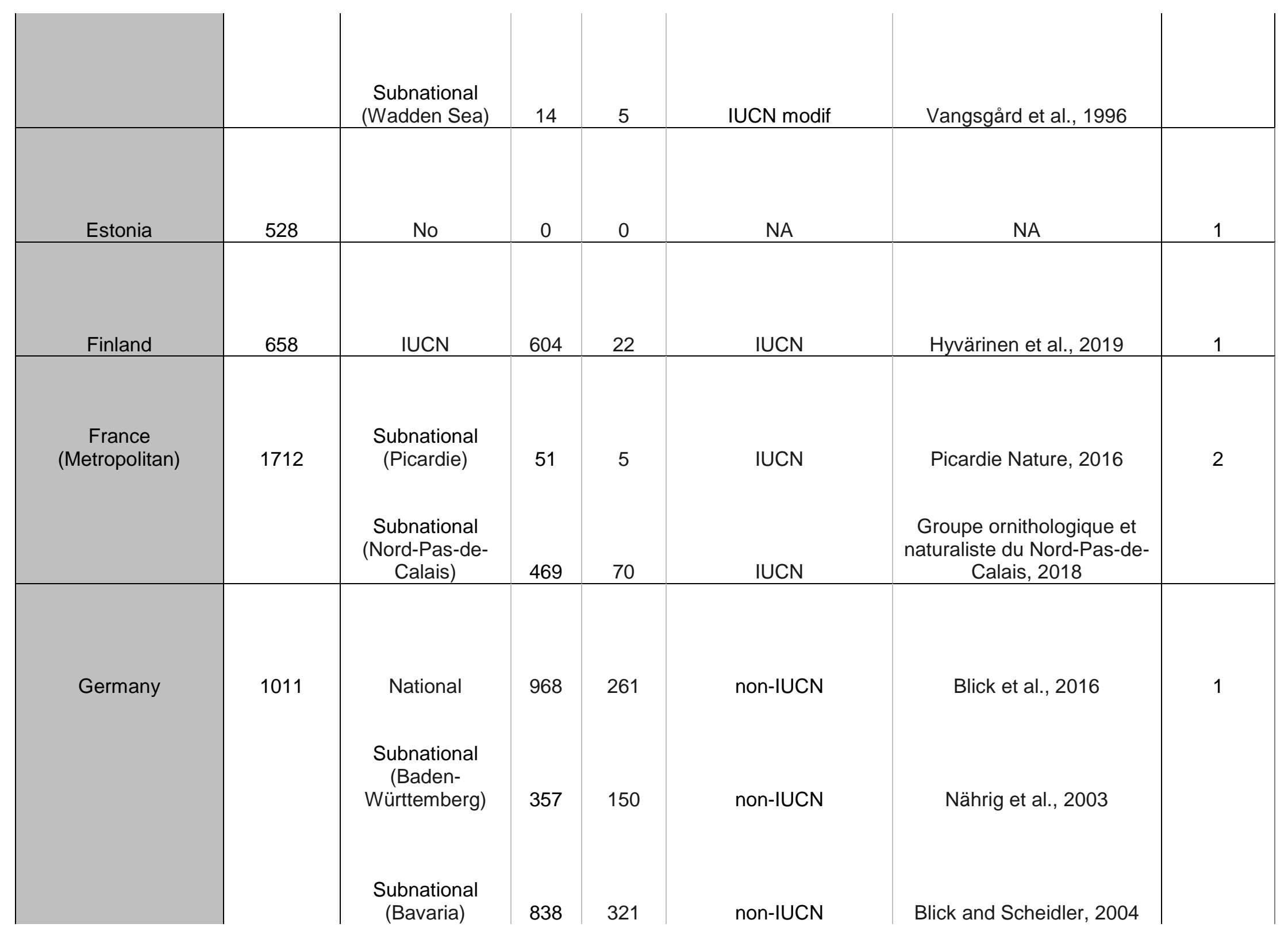




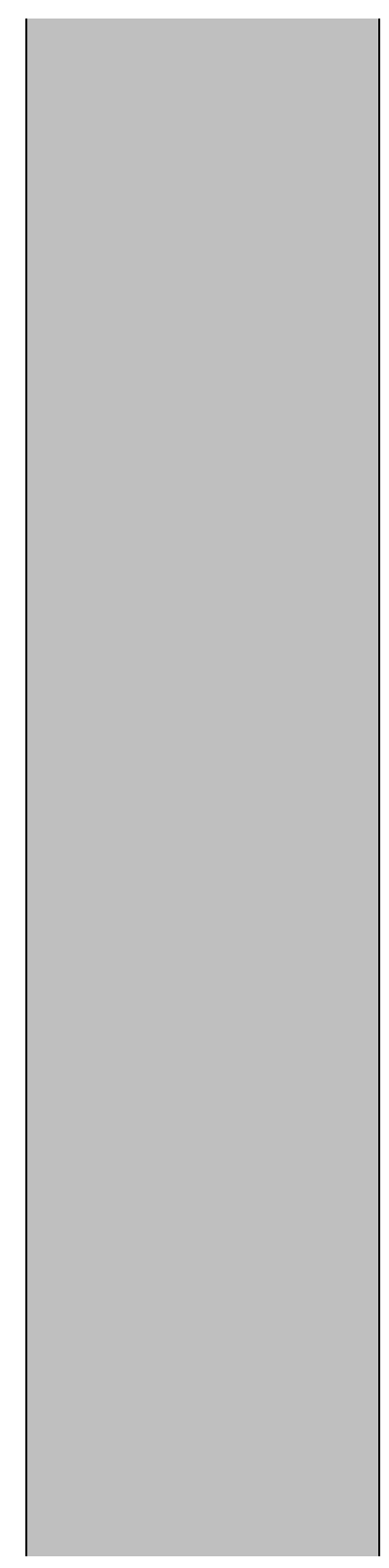

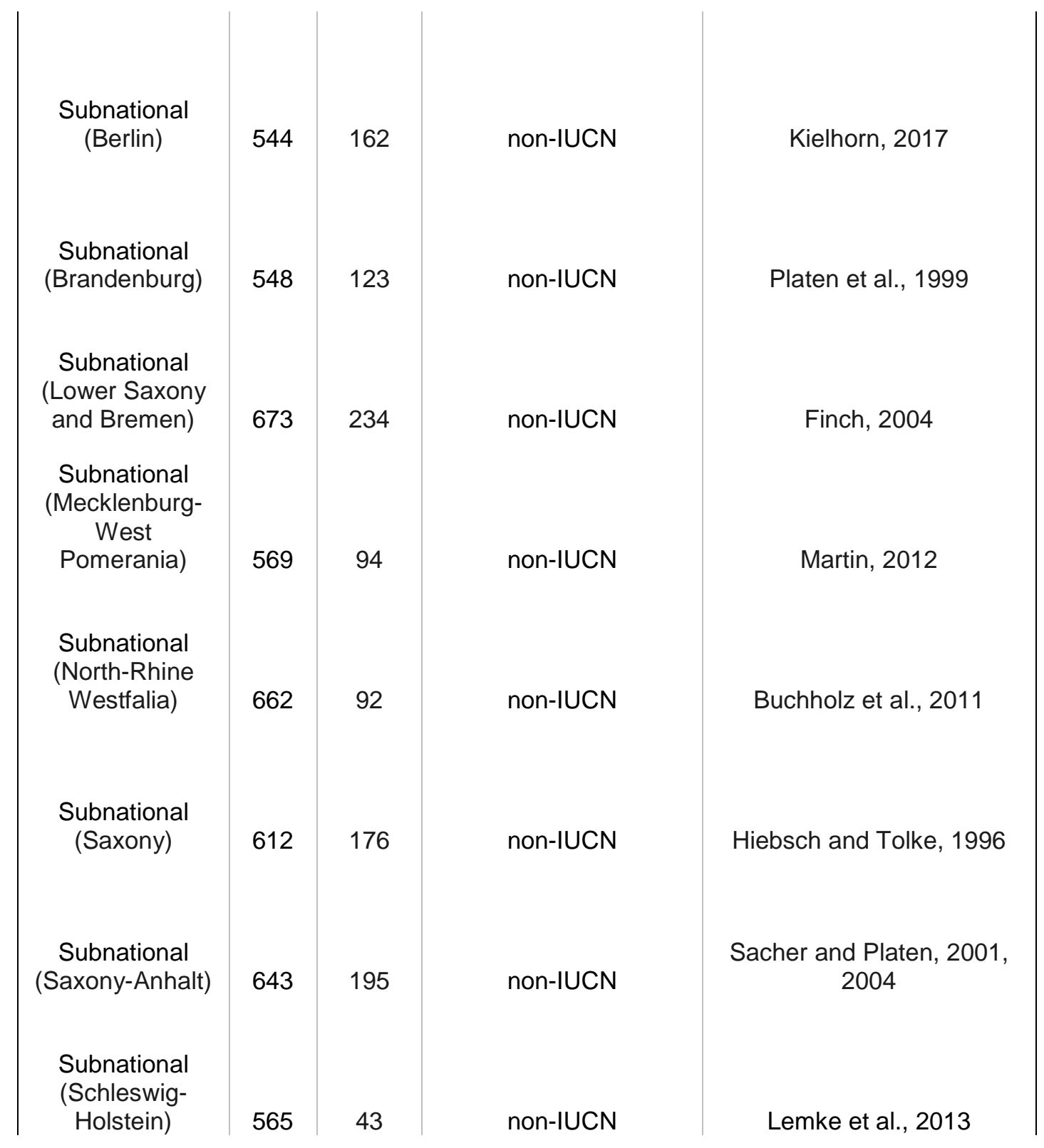




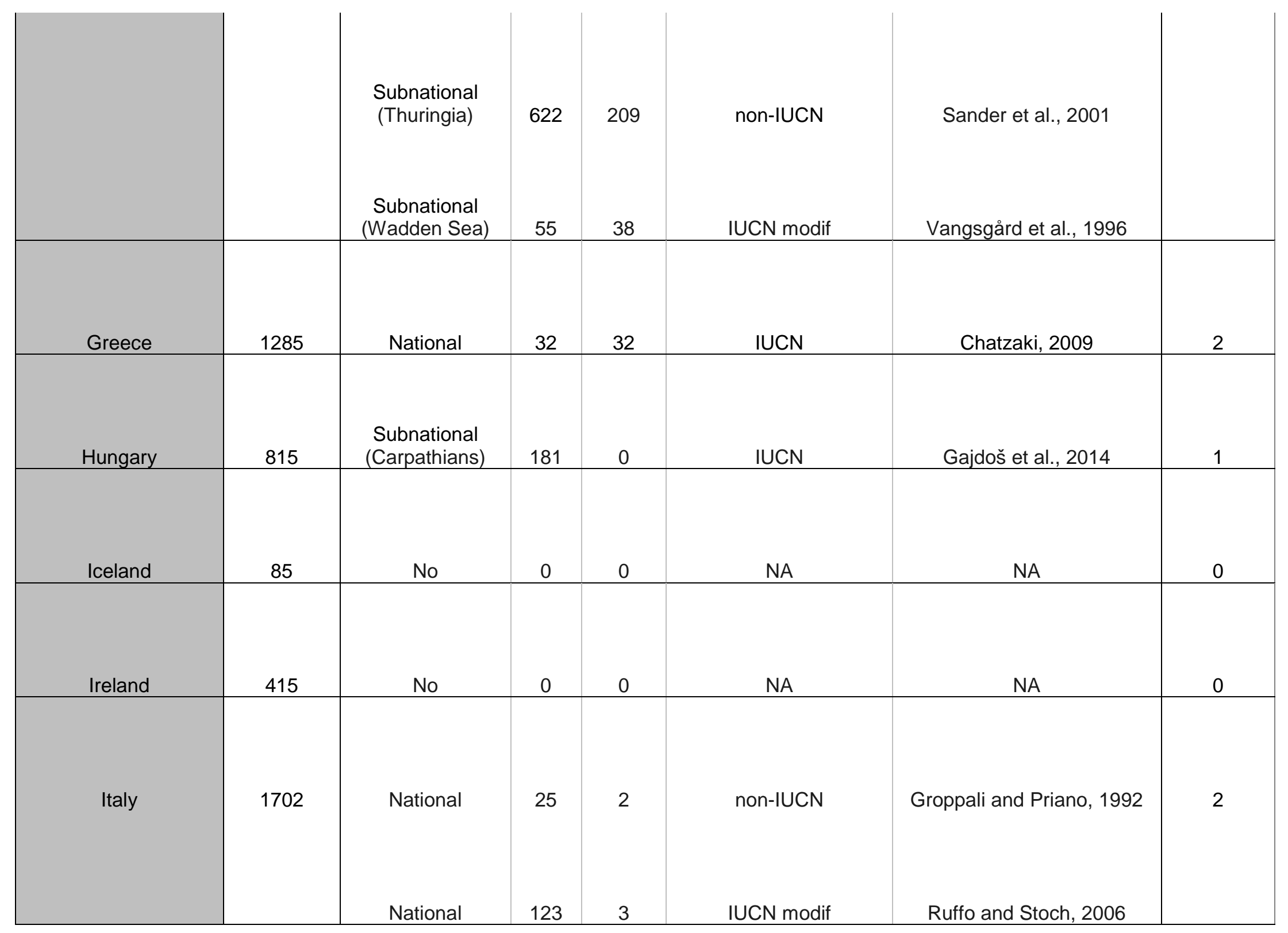




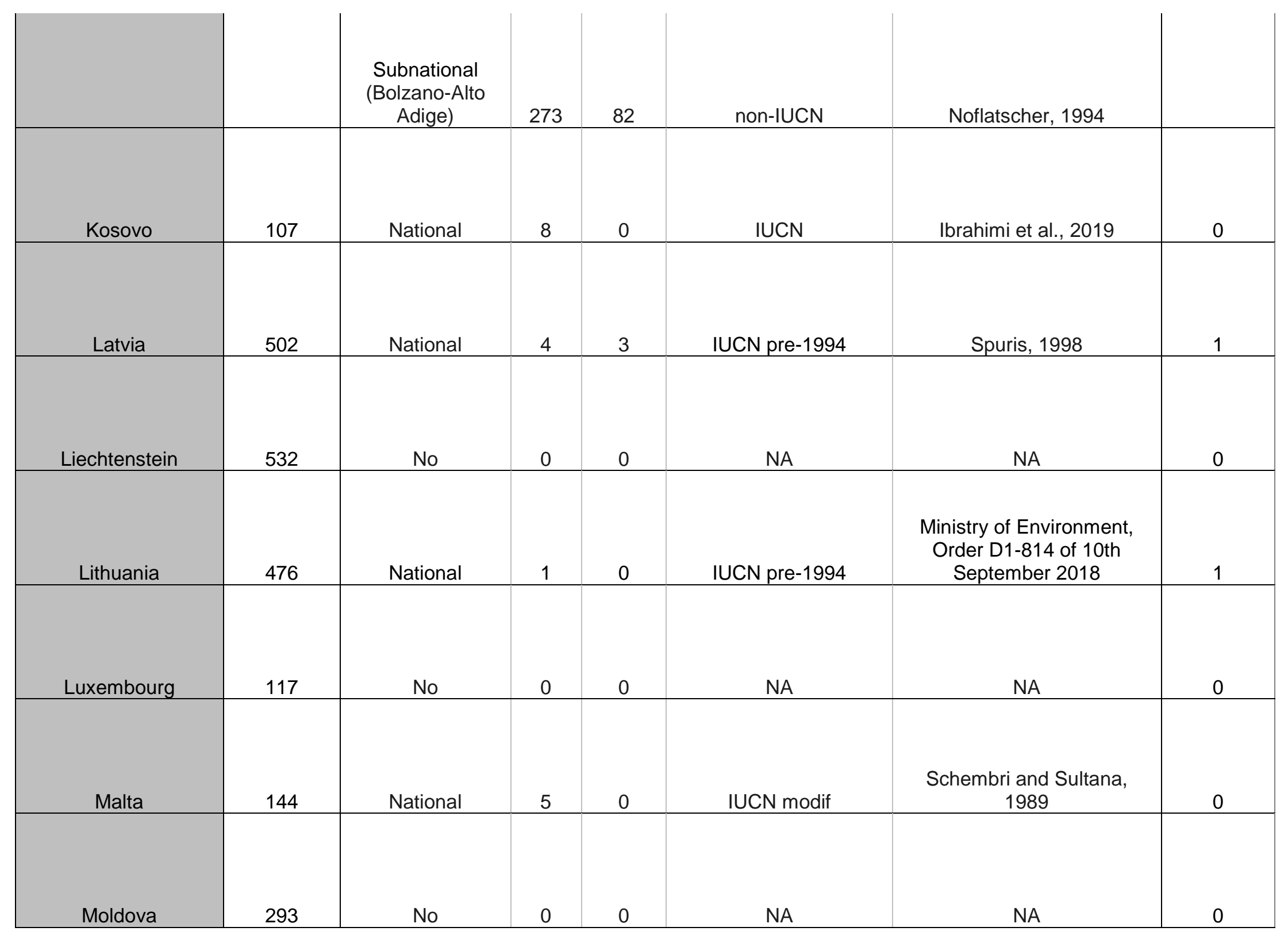




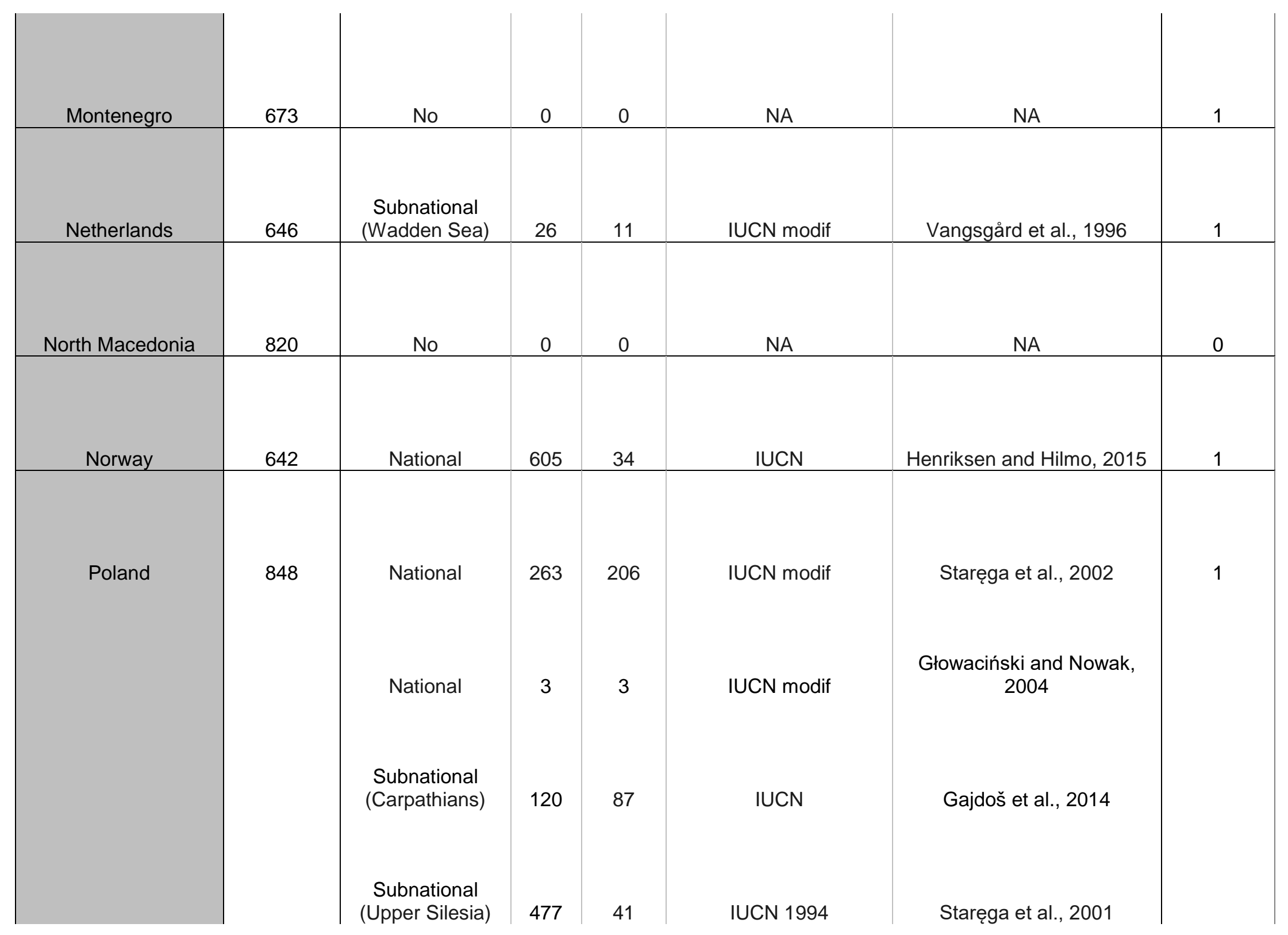




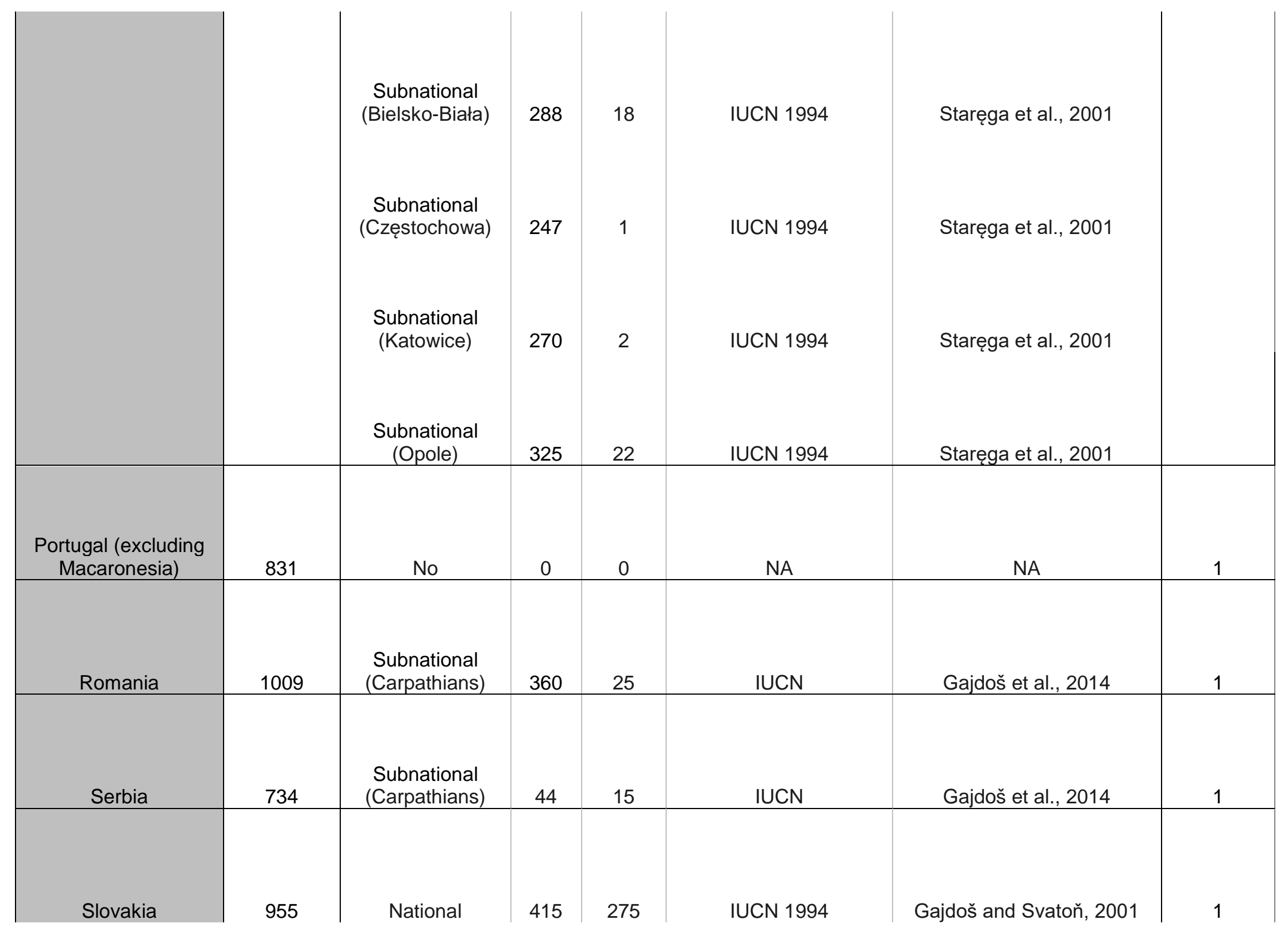




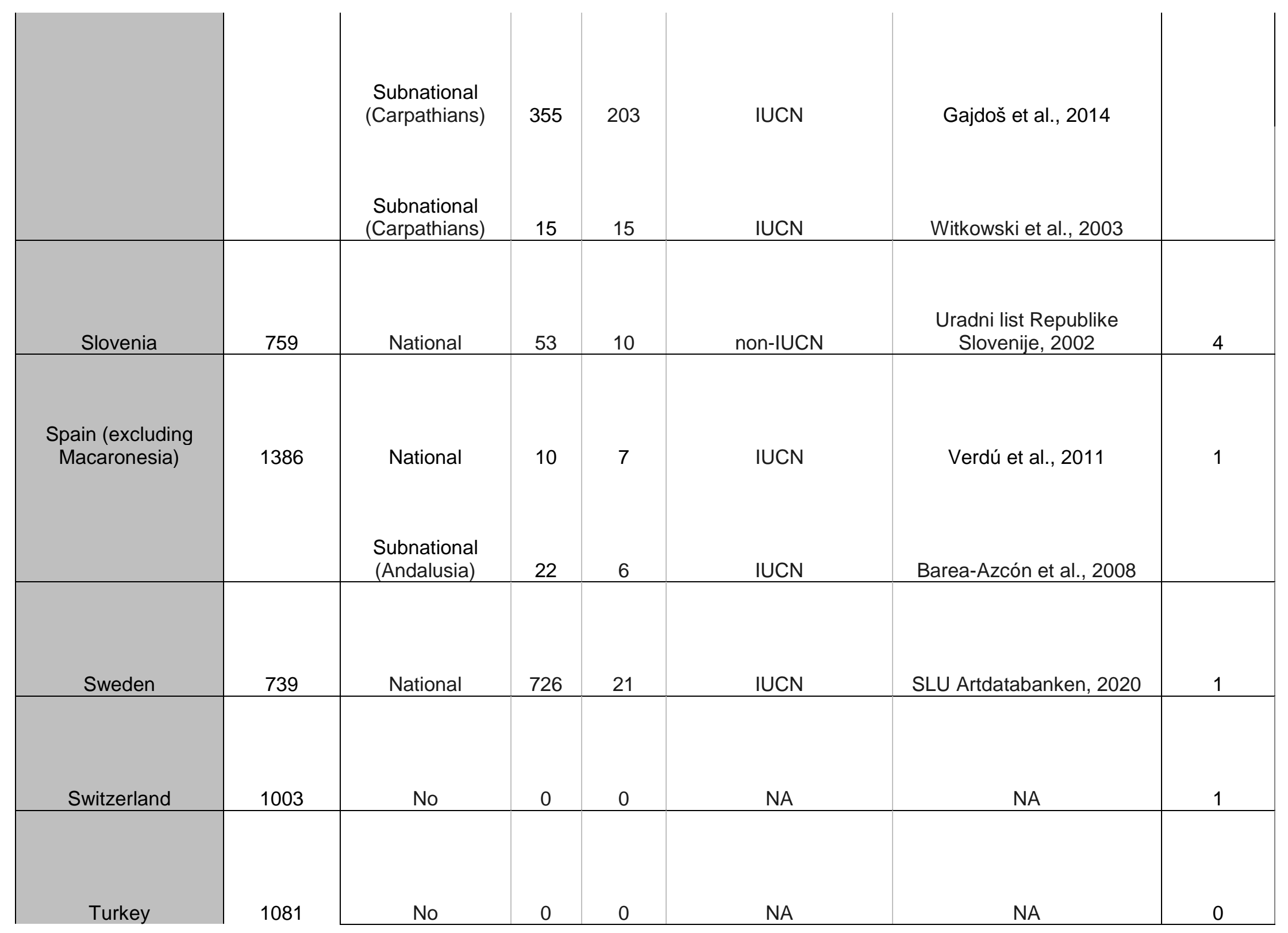




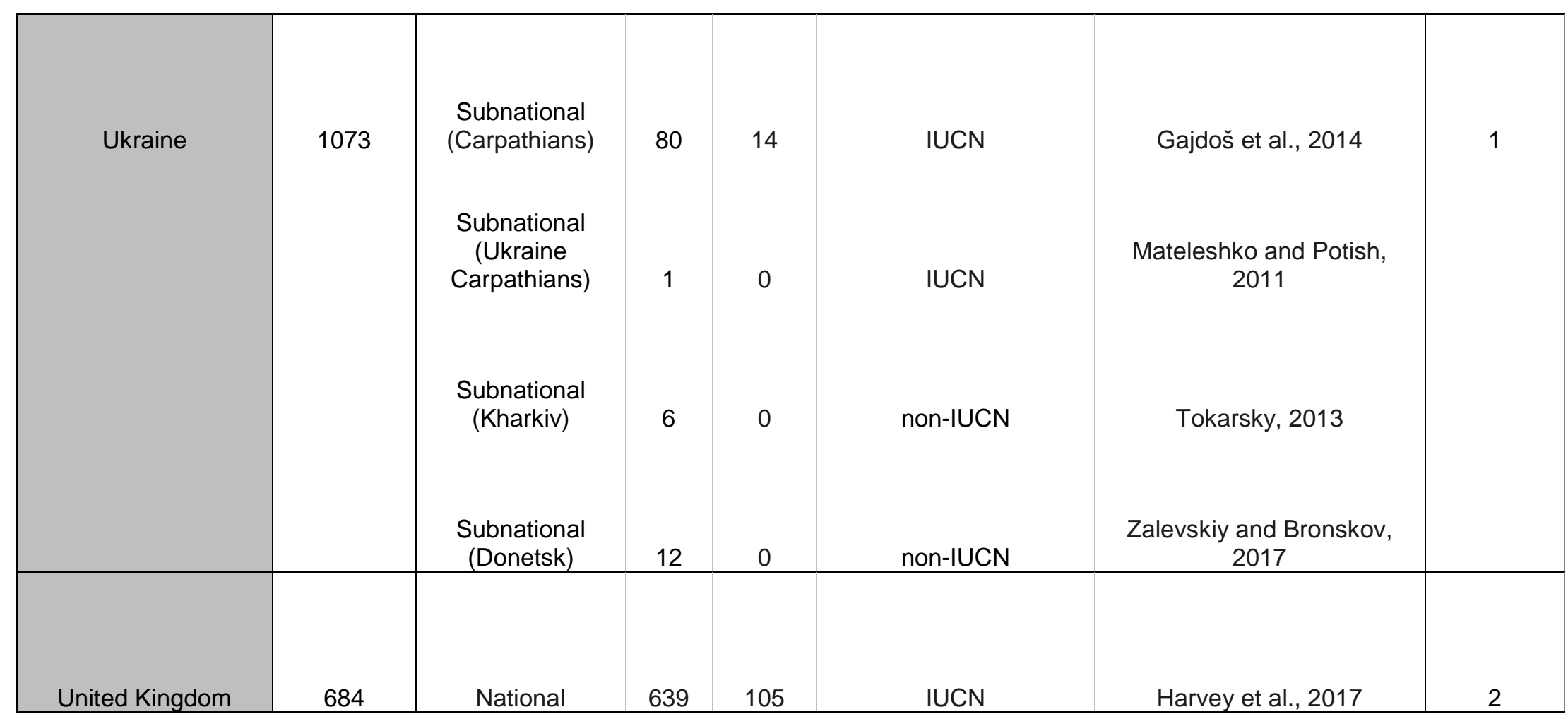


Table 3. - Acts of law concerning spiders in European countries, with number of species and number of protected species.

\begin{tabular}{|c|c|c|c|}
\hline & $\begin{array}{l}\text { Spider } \\
\text { species }\end{array}$ & Legal Acts & $\begin{array}{l}\mathrm{N} \\
\text { species }\end{array}$ \\
\hline Albania & 491 & None & 0 \\
\hline Austria & 1035 & $\begin{array}{l}\text { LGBI. Nr. 70/2007 32. Stück (Carinthia) } \\
\text { LGBI. Nr. 59/2015 (Carinthia) } \\
\text { Vienna Nature Conservation Regulation (Wr. NschVO) }\end{array}$ & $\begin{array}{r}22 \\
109 \\
2\end{array}$ \\
\hline Belarus & 481 & $\begin{array}{l}\text { Law on Protection of The Environment } 1992 \text { no. 1982-XII, } \\
\text { Ministry of Natural Resources and Environmental Protection } \\
\text { Decree } 2014 \text { no. } 26\end{array}$ & 1 \\
\hline Belgium & 743 & Species Decree (Flemish Government Decree 2009) & 4 \\
\hline Bosnia-Herzegovina & 171 & None & 0 \\
\hline Bulgaria & 1045 & None & 0 \\
\hline Croatia & 765 & Nature Protection Act (Official Gazette 70/05, NN 139/2008) & 12 \\
\hline Cyprus & 431 & None & 0 \\
\hline Czech Republic & 893 & None & 0 \\
\hline Denmark & 579 & None & 0 \\
\hline Estonia & 528 & None & 0 \\
\hline Finland & 658 & $\begin{array}{l}\text { Nature Conservation Act 1096/1996, Nature Conservation } \\
\text { Decree 160/1997 Appendix } 4 \text { 471/2013 } \\
\end{array}$ & 2 \\
\hline France (Metropolitan) & 1712 & None & 0 \\
\hline Germany & 1011 & Bundesartenschutzverordnung (BartSchV) 2005 & 6 \\
\hline Greece & 1285 & None & 0 \\
\hline Hungary & 815 & $\begin{array}{l}\text { Government Decree no. 348/2006 (XII.23.), Appendix } 2 \text { of } \\
\text { the Ministerial Decree no. 13/2001 (V.9) Köm }\end{array}$ & 16 \\
\hline Iceland & 85 & None & 0 \\
\hline Ireland & 415 & None & 0 \\
\hline Italy & 1702 & L.R. $10 / 2008$, D.g.r. n. $8 / 7736$ & 2 \\
\hline Kosovo & 107 & None & 0 \\
\hline Latvia & 502 & Regulation nr. 396 of Minister of Cabinet & 1 \\
\hline Liechtenstein & 532 & None & 0 \\
\hline Lithuania & 476 & $\begin{array}{l}\text { Law on the Protected Fauna, Flora and Fungi Species and } \\
\text { Communities (No. VIII-499), Order D1-814 of Ministry of } \\
\text { Environment }\end{array}$ & 1 \\
\hline Luxembourg & 117 & None & 0 \\
\hline Malta & 144 & None & 0 \\
\hline Moldova & 293 & None & 0 \\
\hline Montenegro & 673 & None & 0 \\
\hline Netherlands & 646 & None & 0 \\
\hline North Macedonia & 820 & None & 0 \\
\hline Norway & 642 & None & 0 \\
\hline Poland & 848 & $\begin{array}{l}\text { Decree of the Ministry of Environment 2016, concerning the } \\
\text { Bill of Nature Protection No. 92/2004 }\end{array}$ & 9 \\
\hline $\begin{array}{l}\text { Portugal (excluding } \\
\text { Macaronesia) }\end{array}$ & 831 & Decree Law no. 140/99 Annex B-IV & 1 \\
\hline Romania & 1009 & None & 0 \\
\hline Serbia & 734 & $\begin{array}{l}\text { Official Gazette of the RS no. 5/2010, 47/2011, 32/2016 and } \\
98 / 2016\end{array}$ & 17 \\
\hline
\end{tabular}




\begin{tabular}{|l|r|l|r|} 
Slovakia & 955 & Ministry of Environment Decree SR nr. 158/2014 & 17 \\
\hline Slovenia & 759 & Regulation on the Protection of Endangered Species Ur. I. & 3 \\
\hline & & RS 57/93 & 1 \\
Spain (excluding & & Royal Decree 139/2011 & 1 \\
Macaronesia) & & DOE nr. 30 decreto 37/2001:2349-2364 & 1 \\
\hline Sweden & 1386 & Orden 6/2013 (Valencian Community) & 1 \\
\hline Switzerland & 739 & Species Protection Ordinance SFS 2007:845 Section 6 & 1 \\
\hline & 1003 & None & 0 \\
\hline Ukraine & 1073 & Order z0847-18 no. 237 & 6 \\
\hline United Kingdom & 684 & Wildlife and Countryside Act 1981 Schedule 5 & 12 \\
\hline Turkey & 1081 & None & $2^{*}$ \\
\hline
\end{tabular}

*Note that an additional 38 species are listed as species of "principal importance" for conservation, receiving a lower level of protection under UK laws (see text). 
Table 4. - Spider species in Europe ranked according to their number of occurrences in extinct and/or threatened categories across European National Red Lists and Red Data Books (NRL \& NRDB) (only >5 occurrences are shown).

\begin{tabular}{|l|l|l|c|c|}
\hline \multicolumn{1}{|c|}{ Genus } & \multicolumn{1}{|c|}{ Species } & \multicolumn{1}{|c|}{ Author } & Family & $\begin{array}{c}\text { Occurrences } \\
\text { in NRL \& } \\
\text { NRDB }\end{array}$ \\
\hline Dolomedes & plantarius & (Clerck, 1757) & Pisauridae & 7 \\
Marpissa & radiata & (Grube, 1859) & Salticidae & 7 \\
Argyroneta & aquatica & (Clerck, 1757) & Dictynidae & 6 \\
Brommella & falcigera & (Balogh, 1935) & Dictynidae & 6 \\
Gnaphosa & nigerrima & L. Koch, 1877 & Gnaphosidae & 6 \\
Lasiargus & hirsutus & (Menge, 1869) & Linyphiidae & 6 \\
Midia & midas & (Simon, 1884) & Linyphiidae & 6 \\
Hygrolycosa & rubrofasciata & (Ohlert, 1865) & Lycosidae & 6 \\
Attulus & distinguendus & (Simon, 1868) & Salticidae & 6 \\
Marpissa & pomatia & (Walckenaer, 1802) & Salticidae & 6 \\
Enoplognatha & oelandica & (Thorell, 1875) & Theridiidae & 6 \\
Lasaeola & prona & (Menge, 1868) & Theridiidae & 6 \\
Psammitis & sabulosus & (Hahn, 1832) & Thomisidae & 6 \\
Xysticus & luctator & L. Koch, 1870 & Thomisidae & 6 \\
Atypus & muralis & Bertkau, 1890 & Atypidae & 5 \\
Cheiracanthium & pennyi & O.P.-Cambridge, 1873 & Cheiracanthiidae & 5 \\
Clubiona & juvenis & Simon, 1878 & Clubionidae & 5 \\
Eresus & kollari & Rossi, 1846 & Eresidae & 5 \\
Berlandina & cinerea & (Menge, 1872) & Gnaphosidae & 5 \\
Echemus & angustifrons & (Westring, 1861) & Gnaphosidae & 5 \\
Haplodrassus & minor & (O.P.-Cambridge, 1879) & Gnaphosidae & 5 \\
Carorita & limnaea & (Crosby \& Bishop, 1927) & Linyphiidae & 5 \\
Centromerus & levitarsis & (Simon, 1884) & Linyphiidae & 5 \\
Centromerus & semiater & (L. Koch, 1879) & Linyphiidae & 5 \\
Trichoncus & hackmani & Millidge, 1955 & Linyphiidae & 5 \\
Agroeca & lusatica & (L. Koch, 1875) & Liocranidae & 5 \\
Zora & armillata & Simon, 1878 & Miturgidae & 5 \\
Heliophanus & dampfi & Schenkel, 1923 & Salticidae & 5 \\
Neon & valentulus & Falconer, 1912 & Salticidae & 5 \\
Robertus & ungulatus & Vogelsanger, 1944 & Theridiidae & 5 \\
\hline
\end{tabular}


Table 5. - Spider species in conservation acts in Europe ranked according to the number of countries protecting them (only $>2$ countries are shown).

\begin{tabular}{|l|l|l|c|c|}
\hline \multicolumn{1}{|c|}{ Genus } & \multicolumn{1}{|c|}{ Species } & \multicolumn{1}{c|}{ Author } & Family & $\begin{array}{c}\text { Number of } \\
\text { Countries }\end{array}$ \\
\hline Dolomedes & plantarius & (Clerck, 1757) & Pisauridae & 9 \\
Argyroneta & aquatica & (Clerck, 1757) & Dictynidae & 7 \\
Eresus & kollari & Rossi, 1846 & Eresidae & 7 \\
Atypus & muralis & Bertkau, 1890 & Atypidae & 5 \\
Atypus & affinis & Eichwald, 1830 & Atypidae & 4 \\
Atypus & piceus & (Sulzer, 1776) & Atypidae & 4 \\
Eresus & sandaliatus & (Martini \& Goeze, 1778) & Eresidae & 4 \\
Dolomedes & fimbriatus & (Clerck, 1757) & Pisauridae & 4 \\
Argiope & lobata & (Pallas, 1772) & Araneidae & 3 \\
Arctosa & cinerea & (Fabricius, 1777) & Lycosidae & 3 \\
Macrothele & calpeiana & (Walckenaer, 1805) & Macrothelidae & 3 \\
Araneus & grossus & (C. L. Koch, 1844) & Araneidae & 2 \\
Argiope & bruennichi & (Scopoli, 1772) & Araneidae & 2 \\
Gnaphosa & nigerrima & L. Koch, 1877 & Gnaphosidae & 2 \\
Arctosa & stigmosa & (Thorell, 1875) & Lycosidae & 2 \\
Geolycosa & vultuosa & (C. L. Koch, 1838) & Lycosidae & 2 \\
Philaeus & chrysops & (Poda, 1761) & Salticidae & 2 \\
\hline
\end{tabular}

